In cooperation with the U.S. Environmental Protection Agency

\title{
Lithostratigraphic and Hydrogeologic Characteristics of the Ordovician Sinnipee Group in the Vicinity of Waupun, Fond du Lac County, Wisconsin, 1995-96
}

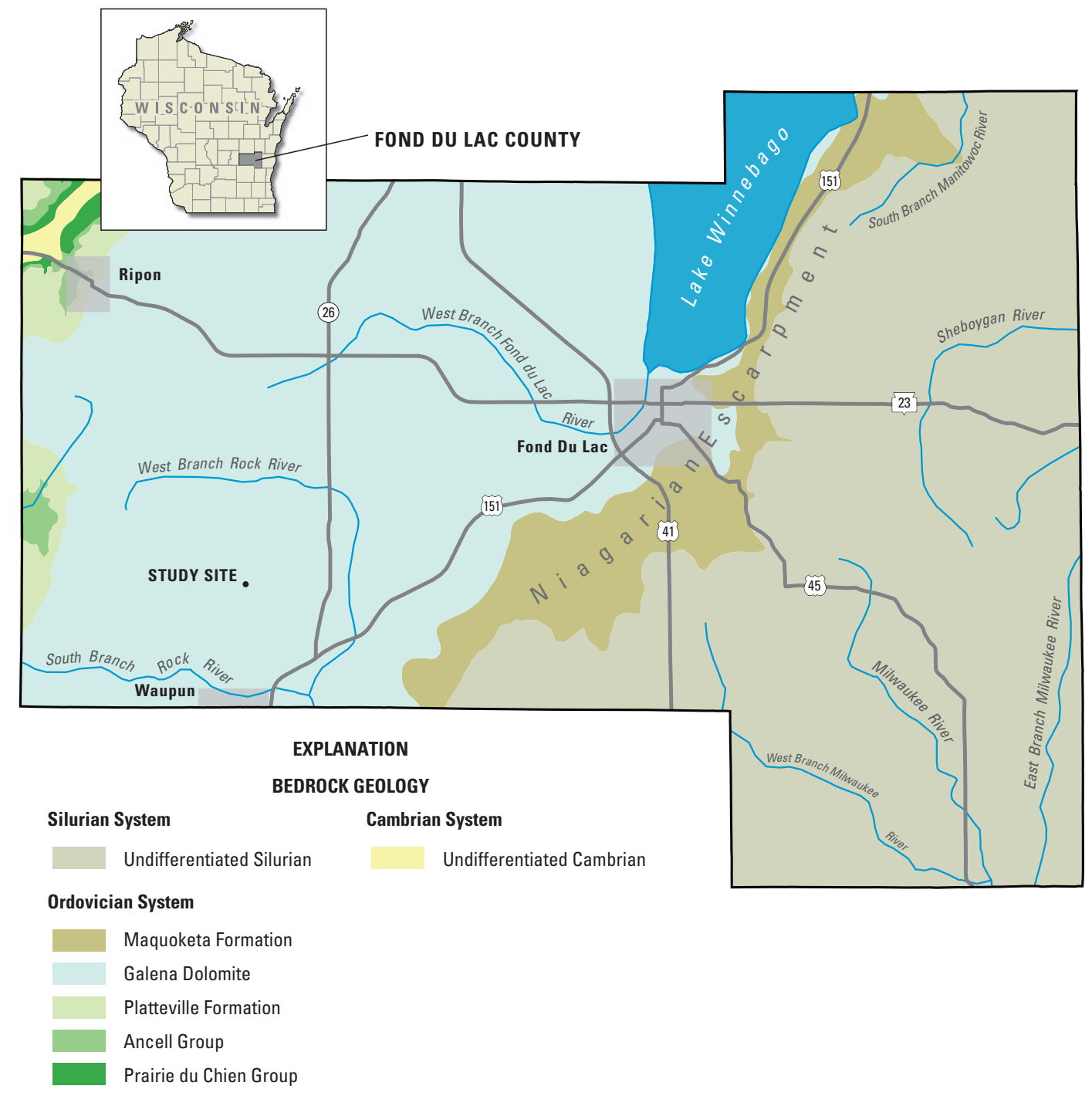

Scientific Investigations Report 2007-5114

U.S. Department of the Interior

U.S. Geological Survey 



\section{Lithostratigraphic and Hydrogeologic Characteristics of the Ordovician Sinnipee Group in the Vicinity of Waupun, Fond du Lac County, Wisconsin, 1995-96}

By Charles P. Dunning and Douglas J. Yeskis

In cooperation with the U.S. Environmental Protection Agency

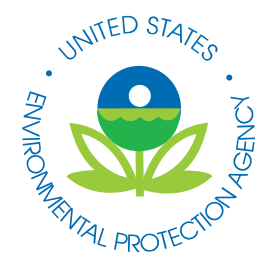

Scientific Investigations Report 2007-5114 


\section{U.S. Department of the Interior DIRK KEMPTHORNE, Secretary}

\section{U.S. Geological Survey \\ Mark D. Myers, Director}

\section{U.S. Geological Survey, Reston, Virginia: 2007}

For product and ordering information:

World Wide Web: http://www.usgs.gov/pubprod

Telephone: 1-888-ASK-USGS

For more information on the USGS — the Federal source for science about the Earth, its natural and living resources, natural hazards, and the environment:

World Wide Web: http://www.usgs.gov

Telephone: 1-888-ASK-USGS

Any use of trade, product, or firm names is for descriptive purposes only and does not imply endorsement by the U.S. Government.

Although this report is in the public domain, permission must be secured from the individual copyright owners to reproduce any copyrighted materials contained within this report.

Suggested citation:

Dunning, Charles P., and Yeskis, Douglas J., 2007, Lithostratigraphic and hydrogeologic characterization of the Ordovician Sinnipee Group in the vicinity of Waupun, Fond du Lac County, Wisconsin, 1995-96: U.S. Geological Survey Report Scientific Investigations Report 2007-5114, 50 p. 


\section{Contents}

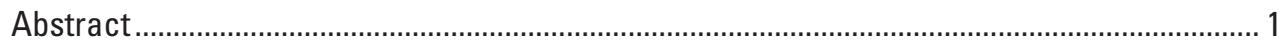

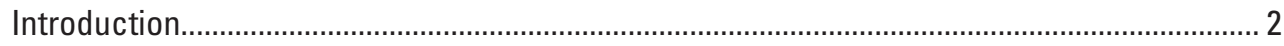

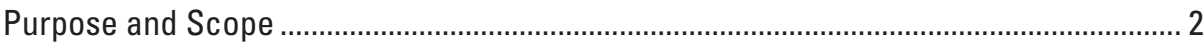

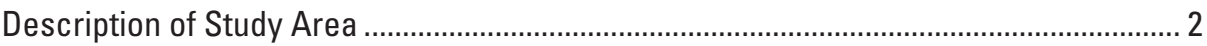

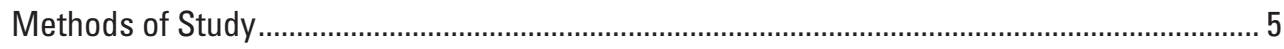

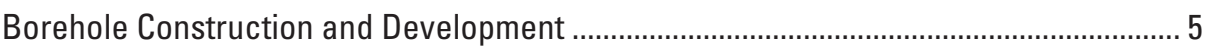

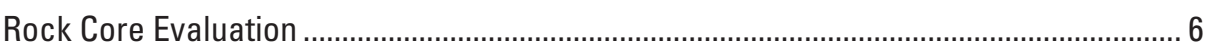

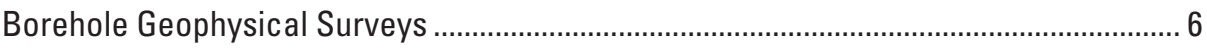

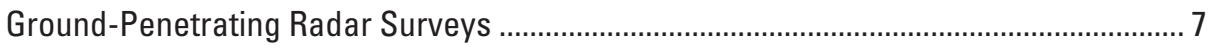

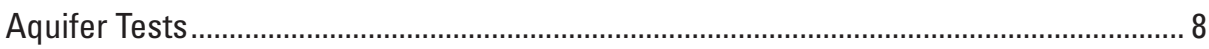

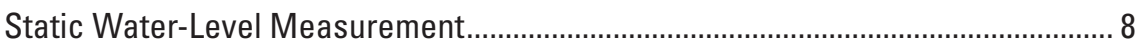

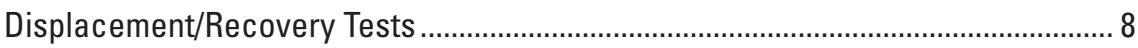

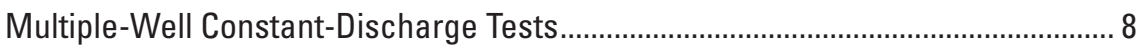

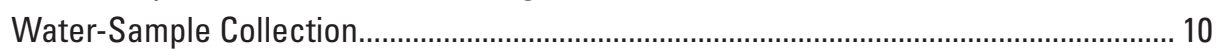

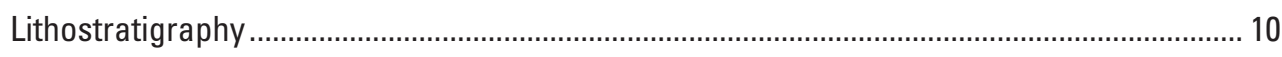

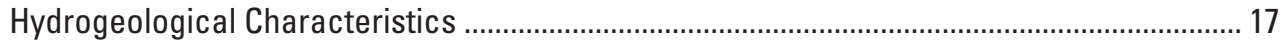

Rock-Matrix Properties........................................................................................... 17

Water Type and Chemical Characteristics.................................................................... 18

Hardgrounds, Fractures, and Bedding-Plane Partings .............................................. 27

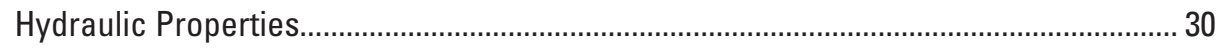

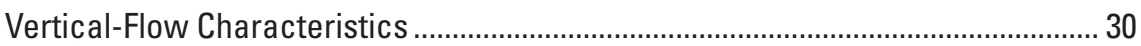

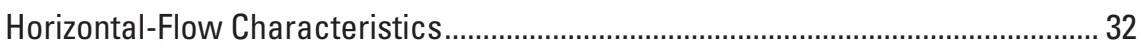

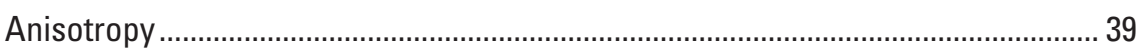

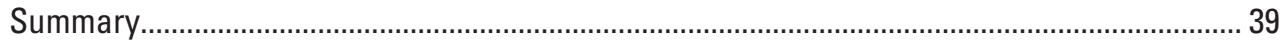

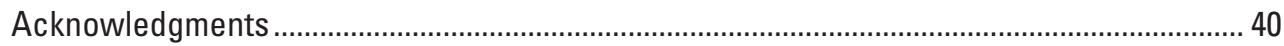

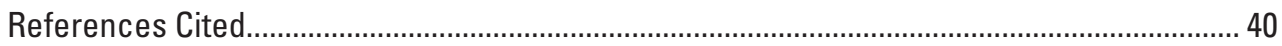

Appendix A: Laboratory Procedures for Porosity and Density Analysis of Rock Core

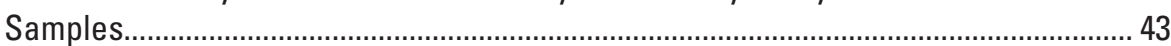

Appendix B: Water levels observed in boreholes above, below, and in the packed interval during multiple-well constant-discharge tests............................................. 45 


\section{Figures}

1. Map showing location of study site in the vicinity of Waupun, Fond du Lac County, Wis.

2. Schematic drawing showing the approximate location of boreholes FL-800, FL-801, and FL-802, and monitoring wells at the study site in the vicinity of

Waupun, Fond du Lac County, Wis.

3. Caliper logs showing intervals isolated by packers for boreholes FL-800, FL-801, and FL-802 at the study site in the vicinity of Waupun,

Fond du Lac County, Wis.

4. Generalized stratigraphy of the study site in the vicinity of Waupun,

Fond du Lac County, Wis.

5-7. Diagrams showing:

5. Geophysical logs, televiewer image, generalized core description, heat-pulse flowmeter data, and relative permeability plot for borehole FL-800 at the study site in the vicinity of Waupun, Fond du Lac County, Wis.

6. Geophysical logs, televiewer image, heat-pulse flowmeter data, and relative permeability plot for borehole FL-801 at the study site in the vicinity of Waupun, Fond du Lac County, Wis.

7. Geophysical logs, televiewer image, heat-pulse flowmeter data, and relative permeability plot for borehole FL-802 at the study site in the vicinity of Waupun, Fond du Lac County, Wis.

8. Attenuation tomagram (a) and velocity tomagram (b) from crossborehole radar data collected between boreholes FL-800 and FL-802 at the study site in the vicinity of Waupun, Fond du Lac County, Wis.

9. Piper diagrams showing hydrogeochemical classification of water from selected intervals of borehole FL-800 at the study site in the vicinity of Waupun, Fond du Lac County, Wis.

10. Selected hydrogeologic features at boreholes Fl-800, FL-801, and FL-802 at the study site in the vicinity of Waupun, Fond du Lac County, Wis

11-14. Plots showing:

11. Slug test data collected from interval $C$ of borehole FL-800 at the study site in the vicinity of Waupun, Fond du Lac County, Wis., and estimated horizontal hydraulic conductivity using Hvorslev equation.

12. Changes in water levels observed in interval $\mathrm{J}$ during multiple-well constant-discharge aquifer tests at the study site in the vicinity of Waupun, Fond du Lac County, Wis.: (a) well is FL-800,

(b) well is FL-801, (c) well is FL-802

13. Changes in water levels observed in interval $\mathrm{K}$ during multiple-well constant-discharge aquifer tests at the study site in the vicinity of Waupun, Fond du Lac County, Wis.: (a) well is FL-800,

(b) well is FL-801, (c) well is FL-802.

14. Multiple-well constant-discharge data collected from interval $\mathrm{J}$ of borehole FL-801 during pumping of borehole FL-800 at the study site in the vicinity of Waupun, Fond du Lac County, Wis., and estimated transmissivity and horizontal hydraulic conductivity using the Cooper and Jacob equation. 


\section{Tables}

1. Diagram showing regional stratigraphy of southern and eastern Wis

2. Abbreviated lithologic description and stratigraphic interpretation by Illinois State Geological Survey of core from borehole FL-800 at the study site in the vicinity of Waupun, Fond du Lac County, Wis.

3. Physical properties of selected rock core intervals in borehole FL-800 at the study site in the vicinity of Waupun, Fond du Lac County, Wis

4. Results of analyses for trace elements, major ions, and physical properties in water samples collected from intervals F, E, D, and C in borehole FL-800 on April 24 and 25, 1996, at the study site in the vicinity of Waupun, Fond du Lac County, Wis.

5. Results of analyses for inorganic constituents in water samples collected from intervals F, E, D, and C in borehole FL-800 on April 24 and 25, 1996, at the study site in the vicinity of Waupun, Fond du Lac County, Wis.

6. Results of analyses for organic compounds in water samples collected from borehole FL-800 during borehole development on April 8 and 9, 1996, and from intervals F, E, D, and C sampled on April 24 and 25, 1996 at the study site in the vicinity of Waupun, Fond du Lac County, Wis

7. Single-hole ground-penetrating radar directional reflection survey indicating the strike directions, dips, and intersection with borehole of reflectors in borehole FL-800 at the study site in the vicinity of Waupun, Fond du Lac County, Wis.

8. Measured static water levels in selected intervals in boreholes FL-800, FL-801, and FL-802 at the study site in the vicinity of Waupun, Fond du Lac County, Wis.

9. Vertical hydraulic gradients calculated between selected intervals in boreholes FL-800, FL-801, and FL-802 at the study site in the vicinity of Waupun, Fond du Lac County, Wis.

10. Horizontal hydraulic conductivity of intervals in boreholes FL-800, FL-801, and FL-802 estimated from slug tests at the study site in the vicinity of Waupun, Fond du Lac County, Wis.

11. Horizontal hydraulic conductivity of intervals in boreholes FL-800, FL-801, and FL-802 estimated from multiple-well constant-discharge aquifer tests at the study site in the vicinity of Waupun, Fond du Lac County, Wis. 


\section{Conversion Factors, Vertical Datum, and Abbreviated Water-Quality Units}

\begin{tabular}{|c|c|c|}
\hline Multiply & By & To obtain \\
\hline \multicolumn{3}{|c|}{ Length } \\
\hline inch (in.) & 2.54 & centimeter $(\mathrm{cm})$ \\
\hline foot (ft) & 0.3048 & meter $(\mathrm{m})$ \\
\hline mile (mi) & 1.609 & kilometer $(\mathrm{km})$ \\
\hline \multicolumn{3}{|c|}{ Hydraulic Conductivity* } \\
\hline foot per day (ft/d) & 0.3048 & meter per day $(\mathrm{m} / \mathrm{d})$ \\
\hline
\end{tabular}

Temperature in degrees Celsius $\left({ }^{\circ} \mathrm{C}\right)$ may be converted to degrees Fahrenheit $\left({ }^{\circ} \mathrm{F}\right)$ as follows:

${ }^{\circ} \mathrm{F}=\left(1.8 x^{\circ} \mathrm{C}\right)+32$

Vertical coordinate information is referenced to the National Geodetic Vertical Datum of 1929 (NGVD 29).

Abbreviated water-quality units used in this report: Chemical concentrations and water temperature are given in metric units. Chemical concentration is given in milligrams per liter (mg/L) or micrograms per liter ( $\mu \mathrm{g} / \mathrm{L})$. Milligrams per liter is a unit expressing the concentration of chemical constituents in solution as weight (milligrams) of solute per unit volume (liter) of water. One thousand micrograms per liter is equivalent to one milligram per liter. For concentrations less than $7,000 \mathrm{mg} / \mathrm{L}$, the numerical value is the same as for concentrations in parts per million. Specific conductance is given in microsiemens per centimeter at 25 degrees Celsius $\left(\mu \mathrm{S} / \mathrm{cm}\right.$ at $25^{\circ} \mathrm{C}$ ).

*Hydraulic conductivity: The standard unit for hydraulic conductivity is cubic foot per day per square foot of aquifer cross-sectional area $\left(\mathrm{ft}^{3} / \mathrm{d}\right) / \mathrm{ft}^{3}$. In this report, the mathematically reduced form, feet per day (ft/d), is used for convenience.

Hydraulic gradient: Hydraulic gradient is given in feet per foot; the difference in measured hydraulic head at two points divided by the distance (vertical or horizontal) between the points of measurement.

Other abbreviations:

$\mathrm{g} / \mathrm{cm}^{3} \quad$ grams per cubic centimeter

$\mathrm{gal} / \mathrm{min}$ gallons per minute

$\mathrm{m} / \mu \mathrm{s} \quad$ meter per microsecond

$\mathrm{ft} / \mu \mathrm{s} \quad$ feet per microsecond 


\title{
Lithostratigraphic and Hydrogeologic Characteristics of the Ordovician Sinnipee Group in the Vicinity of Waupun, Fond du Lac County, Wisconsin, 1995-96
}

\author{
By Charles P. Dunning and Douglas J. Yeskis
}

\section{Abstract}

Three boreholes were drilled at a farm site near Waupun, Wis., to improve the understanding of regional hydrogeology of the Ordovician Sinnipee Group. At the site the Sinnipee Group is the uppermost bedrock unit and is found to be about $183 \mathrm{ft}$ thick. On the basis of core descriptions by the Illinois State Geological Survey, the Sinnipee Group at the site comprises (stratigraphically lowest to highest) the Platteville Formation (about $51 \mathrm{ft}$ thick), the Decorah Formation (about $14 \mathrm{ft}$ thick), and the Galena Dolomite (about $119 \mathrm{ft}$ thick). The Illinois State Geological Survey noted that hardgrounds were common in the rock core, some having stratigraphic significance. Four very well developed hardgrounds were identified, three of which were used as formation or member contacts. The hardground at about $797 \mathrm{ft}$ NGVD 29 represents the top of the Platteville Formation, the hardground at about $754 \mathrm{ft}$ represents the top of the Pecatonica Member of the Platteville Formation, and the hardground at about $746 \mathrm{ft}$ represents the top of the Glenwood Formation.

On the basis of samples collected from one borehole, the ground water at the site is of the calcium-magnesium bicarbonate type. Trichloroethene was detected in one sample at a concentration of $1 \mu \mathrm{g} / \mathrm{L}$, and the concentration of antimony in one sample exceeded the U.S. Environmental Protection Agency (USEPA) Primary Drinking Water Standard. Other water samples contained aluminum and sodium in concentrations that exceeded the USEPA Secondary Drinking Water Standard and the USEPA Drinking Water Equivalent Level, respectively. Samples from various depths contained concentrations of iron, manganese, or dissolved manganese that were near or exceeded the USEPA Secondary Drinking Water Standard.

The cross-borehole radar tomography data show differences in velocity and attenuation among the three major units in the Sinnipee Group. Matrix porosity measured in rock-core samples correlates well with these velocity and attenuation tomograms. The Galena Dolomite has the lowest mean porosity at 2.4 percent ( 7 samples) and is represented in the tomograms as generally having the lowest attenuation and greatest velocity. Below the Galena Dolomite is a transition to a zone with the greatest attenuation and lowest velocity on the tomograms. The rock core shows this interval to be the shaley dolomite of the Decorah Formation which has a mean porosity of 8.3 percent (2 samples). Below the Decorah Formation, the Platteville Formation has a mean porosity of 3.6 percent ( 6 samples) and is represented in the tomograms as having velocity and attenuation generally intermediate between the Galena Dolomite and the Decorah Formation. The evaluation of the single-hole directional ground-penetrating radar reflection survey in FL-800 identified 15 reflectors (secondary permeability features). Some of the reflectors do correlate with fractures and partings noted on geophysical logs and rock core; however, many additional fractures and partings identified by the televiewer log and/or core description were not measured by the borehole radar survey. Horizontal or sub-horizontal reflectors (bedding-plane partings) which do correlate with indications of bedding-plane partings on the acoustic televiewer intersect the borehole at about $917 \mathrm{ft}, 907 \mathrm{ft}, 870 \mathrm{ft}, 805 \mathrm{ft}$, and $797 \mathrm{ft}$.

The flowmeter profiles indicate that water entering and exiting the boreholes at seven bedding-plane partings accounts for most of the total borehole transmissivity. The flowmeter profiles in all three boreholes show that more than 90 percent of the total borehole transmissivity is provided by bedding-plane partings found at $870 \mathrm{ft}$ and higher-stratigraphically within the Galena Dolomite. Static water levels were measured in selected intervals of the three boreholes, and vertical hydraulic gradients were estimated by comparing levels in adjacent intervals. Gradients were found to be almost uniformly downward, ranging 
from -0.040 to $-1.251 \mathrm{ft} / \mathrm{ft}$. On the basis of displacement recovery tests, estimates of horizontal hydraulic conductivity for the isolated intervals in the three boreholes ranged from 0.3 to $61 \mathrm{ft} / \mathrm{d}$. Intervals that included partings had estimated conductivities over the entire range from 0.3 to $61 \mathrm{ft} / \mathrm{d}$; intervals that were primarily rock matrix had estimated conductivities ranging from 0.4 to $5 \mathrm{ft} / \mathrm{d}$. Two intervals were selected for multiple-well constant-discharge testing on the basis of evaluation of the core and geophysical logs, and the relatively high permeability exhibited by displacement/recovery tests. These intervals are within the Galena Dolomite and contain bedding-plane partings that appear to be present in all three boreholes. Multiple-well constant-discharge tests were conducted for each interval independently. The hydraulic conductivity for the stratigraphically higher interval (about 863 to 877 $\mathrm{ft}$ ) ranged from about 94 to $201 \mathrm{ft} / \mathrm{d}$. This conductivity was consistently greater than that estimated for the stratigraphically lower interval (about 803 to $817 \mathrm{ft}$ ) which ranged from 7 to $9 \mathrm{ft} / \mathrm{d}$. During the constant-discharge multiplewell testing of these intervals, a greater hydraulic response was observed between boreholes aligned in a southeastern direction. A lower hydraulic response was observed between boreholes aligned in a northeastern direction, roughly orthogonal to the orientation of greater response.

\section{Introduction}

Most private wells and some municipal-water-supply systems in the vicinity of Waupun, Wis., withdraw water from the Ordovician Sinnipee Group bedrock aquifer (Brown and others, 2000). Ground water in the Sinnipee Group aquifer is generally susceptible to contamination because it is near land surface over much of the study area, and secondary permeability in the form of fractures and bedding-plane partings allow rapid movement of water, providing limited capacity to attenuate contaminants (Brown and others, 2000). Because of this susceptibility to contamination, a better understanding of the hydrogeologic characteristics of the Sinnipee Group aquifer would be very useful in managing and protecting this ground-water supply.

In 1995, the U.S. Geological Survey (USGS), in cooperation with the U.S. Environmental Protection Agency (USEPA), began a hydrogeologic study of the Ordovician Sinnipee Group at a farm site located 4.3 miles north of Waupun, in Fond du Lac County, Wisconsin (fig. 1). Data were collected from three boreholes at the study site to support an ongoing effort by the USEPA and USGS to characterize the hydrogeology of the Sinnipee Group in Wisconsin and the stratigraphically equivalent Galena and Platteville Groups in Illinois. The site north of Waupun was chosen because of its location between previously investigated study sites to the south in northern Illinois and to the north in De Pere, Wisconsin (Batten and others, 1999; Kay and others, 2000).

The study, which began in October 1995 with the drilling of three boreholes (FL-800, FL-801, and FL-802), and concluded in July 1997 with their abandonment, comprised six principal efforts: (1) collection and description of rock core, (2) geophysical logging using conventional techniques, (3) collection of static water-level measurements, (4) aquifer testing, (5) geophysical logging using ground-penetrating radar for single-borehole directional reflection surveys and cross-borehole tomography, and (6) water-quality sampling and analysis.

\section{Purpose and Scope}

This report presents the hydrogeologic properties that were found to be characteristic of the Sinnipee Group near Waupun, Wis., along with water-quality data for seven samples collected from the boreholes on April 8, and May 24 and 25, 1996. This report provides details on the drilling and coring of three boreholes, as well as borehole geophysical data, a description of the rock core, lithostratigraphic interpretation, and density and matrix porosity measurements of 17 core samples. Also discussed is the vertical distribution of static water levels measured in 11 packed intervals and the vertical gradients calculated from those water-level measurements. In addition, this report presents the vertical distribution of estimated horizontal hydraulic conductivity based on displacement/recovery tests and multiple-well constant-discharge aquifer tests.

\section{Description of Study Area}

The study site lies within the Eastern Ridges and Lowlands Geographic Province of Wisconsin (not shown) as defined by Martin (1965). Topography within this province is generally flat to gently rolling, typified by the presence of numerous marshlands. The most prominent topographic feature in Fond du Lac County is a generally northeast-trending dolomite ridge, the Niagarian Escarpment, which is exposed approximately 10 miles east of the site (fig. 1). 


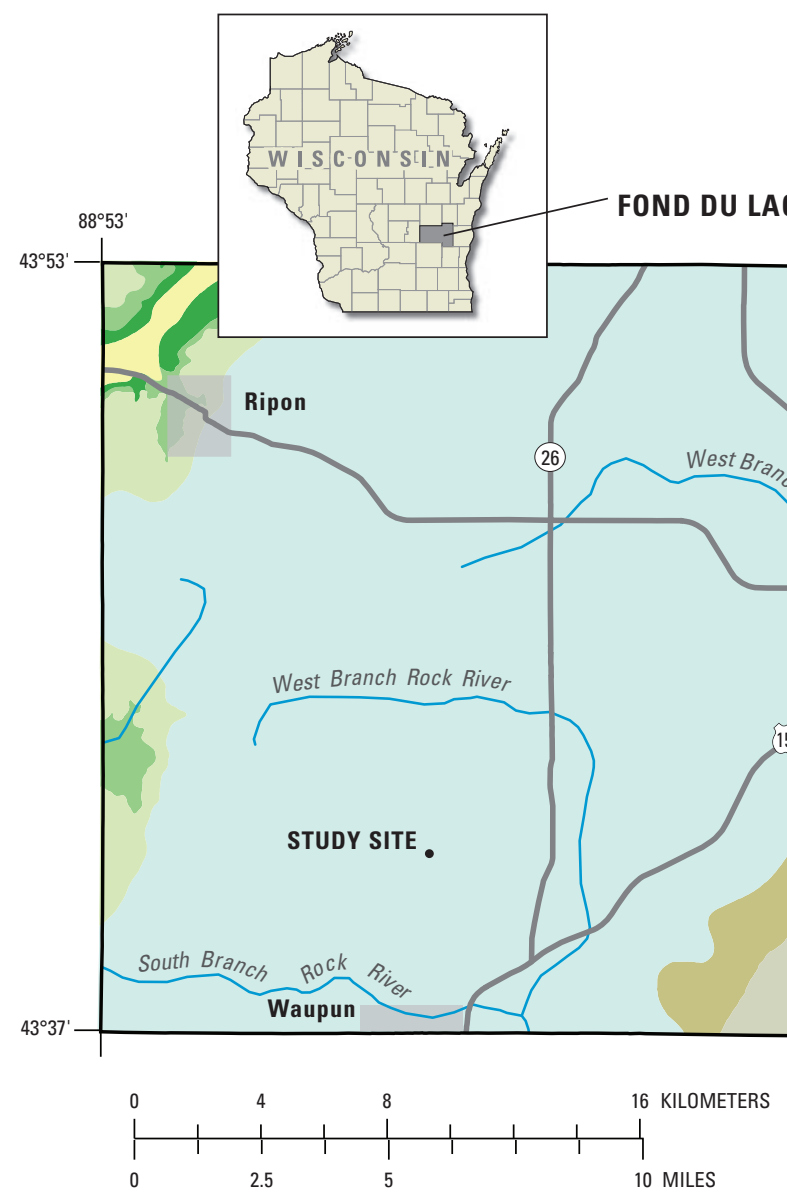

EXPLANATION

BEDROCK GEOLOGY

Silurian System

Undifferentiated Silurian

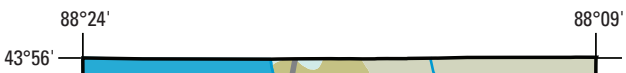

\section{Ordovician System}

\begin{tabular}{|l|}
\hline Maquoketa Formation \\
\hline Galena Dolomite \\
\hline Platteville Formation \\
\hline Ancell Group \\
\hline Prairie du Chien Group
\end{tabular}

\section{Cambrian System}

Undifferentiated Cambrian

Figure 1. Location of study site in the vicinity of Waupun, Fond du Lac County, Wis. 


\section{Lithostratigraphic and Hydrogeologic Characteristics of the Ordovician Sinnipee Group in the Vicinity of Waupun, Wis.}

In southern and eastern Wisconsin, crystalline rocks of the Proterozoic and Archean Eons underlie sedimentary rocks of Cambrian through Devonian Periods (table 1). The sedimentary bedrock dips gently to the east and southeast into the Michigan Basin. The Ordovician Galena-Platteville bedrock unit is identified as the Sinnipee Group in Wisconsin, and as the Galena and Platteville Groups in Illinois (Brown and others, 2000). The Sinnipee Group is considered a confining unit in those areas where it is overlain by other bedrock units; it is generally considered an aquifer where it is the uppermost bedrock unit (subcrop), as in most of northern Illinois and much of central and southern Wisconsin. The Sinnipee Group is predominantly dolomite, though with a greater proportion of limestone in some areas.

In the eastern part of Fond du Lac County, the Ordovician Sinnipee Group is overlain by the younger Ordovician Maquoketa Shale and the Silurian Dolomite (Conlon, 1998). West of the Niagarian Escarpment (fig. 1) the Maquoketa Shale and Silurian Dolomite units are absent (Mudrey and others, 1982), and the Sinnipee Group is considered to be an aquifer. At the study site, the Sinnipee Group bedrock is overlain by a thin layer of unconsolidated deposits (less than $20 \mathrm{ft}$ ) of Quaternary age.

The study site falls within the Glaciated Paleozoic Hydrogeologic Province of Wisconsin (Zaporozec and
Cotter, 1985). Within this province, the site is in the Eastern Drift Hydrogeologic District, which is characterized as a thick, multilayered complex of productive water-bearing Paleozoic sandstone and dolomite with interbedded resistive layers, locally overlain by productive water-bearing sand and gravel.

Nearly all ground water in this area of the State originates as precipitation. Average annual precipitation is 30.15 in. based on data for 1971 to 2000 from the National Oceanic and Atmospheric Administration/National Weather Service Cooperative Observer Network Station at Fond du Lac (Coop Station ID 472839), located approximately 10 mi northeast of the study site (not shown) (Wisconsin State Climatologic Office, 2002). A small amount of recharge may be attributed to infiltration from streams and ponds (Newport, 1962). Ground water in the dolomites of the Sinnipee Group is recharged primarily by the direct downward percolation of precipitation through Quaternary deposits to the water table. As a result, the Sinnipee Group at the study site has likely been exposed to greater infiltration and dissolution than in areas to the east where younger bedrock units overlie it. The general direction of ground-water movement at the site is to the southeast, with a horizontal hydraulic gradient of about 10 to $20 \mathrm{ft}$ per mile (Newport, 1962).

Table 1. Regional stratigraphy of southern and eastern Wisconsin (modified from Conlon, 1998).

\begin{tabular}{|c|c|c|c|}
\hline Geologic age & \multicolumn{2}{|c|}{ Geologic unit } & Principal lithology \\
\hline Quaternary Period & \multicolumn{2}{|l|}{ Unconsolidated deposits } & $\begin{array}{l}\text { Unconsolidated sediments of } \\
\text { gravel, sand, silt, and clay }\end{array}$ \\
\hline Devonian Period & \multicolumn{2}{|l|}{ Devonian dolomite } & Dolomite, shaley \\
\hline Silurian Period & \multicolumn{2}{|l|}{ Silurian dolomite } & Dolomite, shaley \\
\hline \multirow[t]{6}{*}{ Ordovician Period } & \multicolumn{2}{|l|}{ Maquoketa Shale } & Shale, dolomitic \\
\hline & \multirow{3}{*}{ Sinnipee Group } & Galena Dolomite & Dolomite and shale \\
\hline & & Decorah Formation & Dolomite and shale \\
\hline & & Platteville Formation & Dolomite and shale \\
\hline & \multirow{2}{*}{ Ancell Group } & Glenwood Formation & Dolomite, shaley \\
\hline & & St. Peter Sandstone & Sandstone \\
\hline \multirow[t]{4}{*}{ Cambrian Period } & \multicolumn{2}{|l|}{ Prairie du Chien Group } & Dolomite, cherty \\
\hline & \multicolumn{2}{|l|}{ Trempealeau Group } & Sandstone \\
\hline & \multicolumn{2}{|l|}{ Tunnel City Group } & Sandstone \\
\hline & \multicolumn{2}{|l|}{ Elk Mound Group } & Sandstone \\
\hline Proterozoic and Archean Eons & \multicolumn{2}{|l|}{ Undifferentiated } & Crystalline rock \\
\hline
\end{tabular}




\section{Methods of Study}

Data collection at the study site involved construction and development of boreholes, rock coring, borehole geophysics, ground-penetrating radar, displacement/recovery and multiple-well constant-discharge aquifer tests, and water-quality sampling. The methods employed for collection of these data are discussed below.

\section{Borehole Construction and Development}

Three boreholes-identified as FL-800, FL-801, and FL-802 - were drilled from October 13 through 19, 1995. FL-802 was drilled $82 \mathrm{ft}$ to the southeast of FL-800 (fig. 2 ), and FL- 801 was drilled $58 \mathrm{ft}$ to the west of FL-802. The horizontal distance between FL-800 and FL-801 could not be measured directly because a building is located between the two boreholes. A surveying level was used to determine the angle created by the three boreholes and the distance between FL-800 and FL-801 was calculated to be about $70 \mathrm{ft}$.

The three boreholes were drilled using a Portadrill $524 \mathrm{air} / \mathrm{mud}$ rotary rig. The general drilling procedure used for each borehole follows.

1. Drill a nominal 97/8-in. borehole through approximately $16 \mathrm{ft}$ of unconsolidated Quaternary deposits and about $3 \mathrm{ft}$ into the top of the bedrock.

2. Set 6-in. steel casing in the borehole and fill the annulus with cement grout.

3. Drill a nominal 6-in. borehole to a total depth (TD) of $206 \mathrm{ft}$.

An exception to the above procedure was FL-800, which was cored from the bottom of the 6-in. casing to TD. The coring resulted in the recovery of 3 -in. diameter rock core and left a borehole about 5-in. in diameter. Following completion of coring operations, the borehole was reamed to a nominal 6-in. diameter.

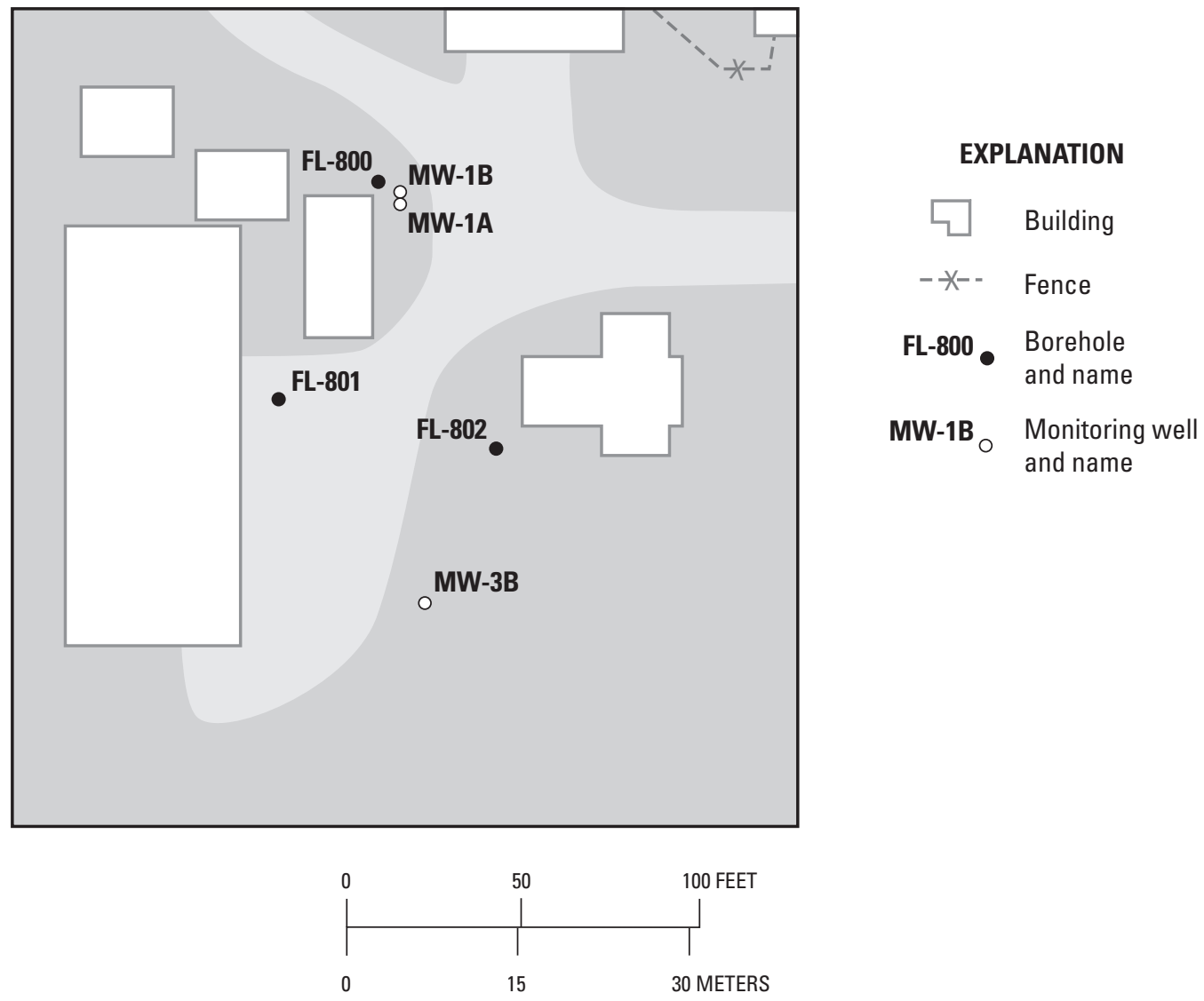

Figure 2. Approximate location of boreholes FL-800, FL-801, and FL-802, and monitoring wells at the study site in the vicinity of Waupun, Fond du Lac County, Wis. 


\section{Lithostratigraphic and Hydrogeologic Characteristics of the Ordovician Sinnipee Group in the Vicinity of Waupun, Wis.}

The top of casing of FL-800 was established as the site datum with an elevation of $950 \mathrm{ft}$ above NGVD 29 using USGS topographic maps. Using a surveying level, the relative elevations of the top of casing of FL-801 and FL-802 were measured to be $952.00 \mathrm{ft}$ and $950.10 \mathrm{ft}$ respectively. The top of the casing of FL-800 was used as the datum for all geophysical logging and aquifer testing. The ground surface at FL-800 (estimated to be $949 \mathrm{ft}$ ) was the datum for the rock core.

Borehole development requires that water be pumped from the productive intervals of the borehole at sufficient rates and total volumes to overcome the effects of drilling. These three boreholes were developed on April 8 and 9, and May 23, 1996, by lowering an electric pump to the bottom of each borehole and pumping at a rate of about 30 gal/min for approximately 110 minutes. During development, each pumped borehole was monitored with pressure transducers and a data logger, as was each of the other boreholes and three existing monitoring wells, MW-1A, MW-1B, and MW-3B (fig. 2). Only FL-800 and FL-802 were developed during the first visit because an inflatable packer was stuck in FL-801 at about $60 \mathrm{ft}$ of depth $(890 \mathrm{ft}$ above NGVD 29), preventing pump placement. The packer was recovered from FL-801 and the borehole was developed on May 23, 1996. FL-800 was developed a second time on May 23, 1996, because of low confidence in the drawdown data collected during the original development of the borehole.

\section{Rock Core Evaluation}

The rock core recovered from FL-800 was delivered to the Illinois State Geological Survey (ISGS) on February 7, 1996, for lithologic description and stratigraphic interpretation. The core was transferred to the USGS Illinois Water Science Center on March 21, 1996, for the determination of rock matrix properties of 17 samples of the core using methods described in Appendix A (Patrick Mills, U.S. Geological Survey, written commun., 1996); the specific matrix properties determined were porosity, grain density, and bulk density.

\section{Borehole Geophysical Surveys}

Natural gamma, short-normal resistivity, spontaneous potential, fluid resistivity, caliper, and acoustic televiewer tools, as well as a heat-pulse flowmeter, were run in all three boreholes on October 30 and 31, 1995. In addition, a neutron log was run in FL-800. Brief descriptions of these electric logging methods follow; however, Keys (1990) and Kay and others (2004) provide detailed explanations of the use of these logs in interpreting lithologic properties.

The natural gamma log records the amount of radiation emanating from naturally occurring sources in the rock, including uranium, thorium, and potassium. The amount of radiation emitted by most sedimentary rocks is related directly to the clay content.

Resistivity logs are electric logs that measure formation resistance to an electric current between an electrode on the tool moving up the borehole and an electrical ground at land surface. Generally, resistance to the imposed electric current decreases with increasing porosity, borehole diameter, fracture density, and concentration of dissolved solids in the water. For the short-normal resistivity tool, the spacing between the current-emitting and potential-measuring points is set at $16 \mathrm{in}$. As with other electric logs, the effectiveness of these $\operatorname{logs}$ is affected by vertical flow within a borehole that may obscure differences in the electrical resistivity and conductivity of the water.

The spontaneous potential (SP) log is an electric log that measures the natural differences in electrical potential between an electrode in the borehole and a reference electrode at land surface. SP logging can be done only in the uncased part of water- or mud-filled boreholes. Changes in SP voltage require the presence of water with differing chemical properties in the aquifer, a means of segregating these waters within the aquifer, and a point where the waters mix. SP $\log$ s can be used to identify primary and secondary permeability features in the borehole. Normal and SP resistivity logging can provide information on changes in lithology and water quality, indicating the presence of secondary permeability features.

The caliper log is a mechanical tool that measures the inside diameter of a borehole. Caliper logs can be run in cased or open holes, and in fluid- or air-filled holes. Changes in borehole diameter identified with the caliper logs can be associated with a variety of borehole features including fractures, washouts, solution openings, large vugs, and well casing and screens.

The neutron log is created by measuring the returning signal from a source that emits neutrons into the formation. The emitted neutrons interact with hydrogen in the formation; the amount of neutron energy adsorption is directly proportional to the hydrogen content. The hydrogen content is an indicator of water content, and by extension, formation porosity. 
The acoustic televiewer scans the borehole with an acoustic beam generated by a rotating, rapidly pulsed piezometric source as the tool is moved through the borehole. The amplitude and traveltime of acoustic signals reflected from the wall are measured. A smooth, hard borehole wall produces a uniform acoustic reflection; the presence of a secondary porosity feature such as a fracture, a vuggy interval, or a solution feature in the borehole scatters the acoustic reflection, producing a dark feature on the televiewer image. In this way, televiewer images can be used to identify the type, apparent size, and orientation of secondary permeability features intercepting the uncased part of a borehole below the water table.

The heat-pulse flowmeter measures the velocity and direction of vertical flow at various depths in an uncased borehole. In a borehole of known diameter, water velocity can be converted to flow volume, which can be plotted to profile the vertical distribution of flow. Depth intervals where there are appreciable changes in the volume of flow between measurement stations are interpreted as intervals over which there is inflow to, or outflow from, the borehole. The amounts of water entering and exiting a borehole under any given hydraulic condition is proportional to the product of fracture permeability and the head difference driving the flow. A relative permeability profile can be obtained by subtracting flow rates in a borehole measured under two different head conditions. Ambient and steady injection were used as two different head conditions in evaluating the boreholes at the study site; the data were plotted as discrete flowmeter measurements (data) and as "step profiles" (interpretation) for each borehole (Paillet, 1998; Paillet, 2000).

\section{Ground-Penetrating Radar Surveys}

Ground-penetrating radar (GPR) uses the transmission and reflection of radar-frequency electromagnetic waves to detect variations in subsurface properties. GPR can be used in a single borehole for a directional reflection survey (transmitter and receiver in the same borehole) or in two boreholes for a cross-borehole GPR tomography survey (transmitter in one borehole and receiver in the other).

A single-borehole directional radar reflection survey was conducted in borehole FL-800 using a 60-MHz transmitter and a 60-MHz directional receiver. Single-borehole directional radar reflection surveys have been used to identify the location and orientation of radar reflectors that may be associated with secondary permeability features (including fractures) at distances of 10 to $100 \mathrm{ft}$ from the borehole (Falk, 1992; Lane and others, 1994). The reflectors identified in the single-borehole survey can be compared to the interpretation of fractures provided by the acoustic televiewer.

A cross-borehole GPR tomography survey was conducted between boreholes FL-800 and FL-802. Crossborehole GPR surveys measure the velocity and attenuation of the radar pulse between the two investigated boreholes. Cross-borehole tomography is the process by which a two-dimensional depiction of physical properties in the plane between two boreholes is made. For this survey, the transmitting antenna was placed in borehole FL-802 and the receiving antenna in FL-800. Many individual radar scans were made by positioning the receiver at regular intervals in the borehole. Variations in the velocity of the pulse through the dolomite were affected primarily by the presence of water-bearing porous matrix and fractures. Velocity data were used to calculate the porosity of the dolomite deposits between the two boreholes. Variations in the attenuation of the pulse are affected primarily by the mineralogy and competence of the rock. Areas of variation in the velocity and attenuation of the signal identified from the cross-borehole radar-tomography survey can be interpreted as lithologic boundaries or intervals of variation in primary or secondary porosity. Intervals of low signal velocity and high attenuation typically are associated with elevated porosity or high amounts of clay minerals.

The cross-borehole radar tomography survey between boreholes FL-800 and FL-802 was conducted using a 22-MHz transmitter. Data collected for the cross-borehole survey consisted of measurements at points in a $12.8 \mathrm{x}$ $12.8 \mathrm{ft}(4 \mathrm{x} 4 \mathrm{~m})$ grid from $26 \mathrm{ft}$ to $180 \mathrm{ft}$ below the top of casing (924 to $770 \mathrm{ft}$ above NGVD 29), with "level-run" or common source-receiver data collected every $1.6 \mathrm{ft}(0.5 \mathrm{~m})$ from $19 \mathrm{ft}(6 \mathrm{~m})$ to $183 \mathrm{ft}(57 \mathrm{~m})$ between the boreholes. A more dense data set is usually desired for a cross-borehole survey, but site and equipment restrictions prevented the collection of these data. Vertical deviation logs are necessary to accurately determine the spatial locations of the transmitter and receiver in each borehole. Deviation logs, however, were not available for these boreholes, so for the analysis it was assumed that the boreholes do not depart from vertical. Tomograms were generated using TOMOCG (Ivansson, 1984; Day-Lewis and Lane, 2003), a PC-based inversion software provided by the RAMAC borehole-radar instrument manufacturer. Day-Lewis and Lane (2003) provide additional explanation on the use of cross-borehole radar tomography. 


\section{Aquifer Tests}

Two types of hydraulic aquifer tests were conducted, displacement/recovery and multiple-well constant-discharge tests. The tests were performed on selected intervals (isolated using inflatable packers) in each of the boreholes. On the basis of inspection of the rock core from FL-800 and results of geophysical logging in all three boreholes, 11 intervals were selected for further evaluation in borehole FL-800 and 2 intervals in each of boreholes FL-801 and FL-802 (fig. 3). These intervals were chosen to evaluate the range of horizontal hydraulic conductivity (K) of the rock intersected by the borehole. The lithology of intervals chosen ranged from competent dolomite rock matrix to bedding-plane partings.

\section{Static Water-Level Measurement}

Static water levels were measured in each of the isolated intervals using an electric tape measure. Vertical hydraulic gradients were estimated by comparing static water levels measured in the intervals.

\section{Displacement/Recovery Tests}

Displacement/recovery tests (also called slug tests) are initiated by quickly lowering a solid cylinder (slug) below the water surface in a borehole causing the water level to quickly rise. The change in water level in the borehole due to the slug and the recovery of water level to a static level (falling-head test) were measured using a pressure transducer and recorded using a data logger. Slug tests were conducted using a 10-ft long solid polyvinyl chloride slug with a 0.625 -in. radius. The riser pipe above the isolated intervals in which the slug was lowered had a 0.935-in. radius. Considering the volume of the riser pipe and the volume of the fully submerged slug, the initial rise in water level in the riser pipe was about $4.5 \mathrm{ft}$. All slug tests were conducted using the solid slug with the exception of those for intervals $\mathrm{E}$ and F in FL-800. Because the water column over the packed interval was insufficient, slugs of 1 and 2 gallons of distilled water were used for intervals $\mathrm{E}$ and F, respectively (fig. 3).

Displacement/recovery data were analyzed using the technique of Hvorslev (1951). This technique was developed for use in unconfined conditions and can be applied to boreholes that fully or partially penetrate a formation. The following conditions are assumed in the application of the Hvorslov technique:
1. Drawdown of the water table in the vicinity of the borehole during the test is negligible,

2. Unsaturated flow above the water table can be ignored,

3. Head losses as the water enters the borehole are negligible, and

4. The hydraulic unit is homogeneous and isotropic.

These conditions are likely to be met or approximated at the site boreholes over the small volume of rock affected by the tests.

The Hvorslev equation used in estimating $\mathrm{K}$ is

$$
\mathrm{K}=\frac{\mathrm{r}_{\mathrm{c}}{ }^{2} \ln \left(\frac{\mathrm{L}}{\mathrm{r}_{\mathrm{w}}}\right)}{2 \mathrm{LT}_{1}},
$$

Where,

$$
\begin{aligned}
& \mathrm{K}=\text { horizontal hydraulic conductivity, } \\
& r_{c}=\text { effective radius of the well casing }(0.078 \\
& \text { feet for all tests), } \\
& \mathrm{r}_{\mathrm{w}}=\text { effective radius of the well }(0.25 \text { feet for all } \\
& \text { tests), } \\
& \mathrm{L}=\text { length of isolated interval (varies by test), } \\
& \text { and } \\
& \mathrm{T}_{1}=\text { time required for the head increase in the } \\
& \text { well bore to dissipate. }
\end{aligned}
$$

\section{Multiple-Well Constant-Discharge Tests}

The hydraulic connection through specific permeable intervals between the three boreholes was evaluated by multiple-well constant-discharge aquifer tests in which water is pumped at a constant rate from one borehole, and changes in water level are observed in the pumped borehole and the other two. Packed intervals $\mathrm{J}$ and $\mathrm{K}$ were selected for multiple-well constant-discharge testing on the basis of evaluation of the core and geophysical logs, and the relatively high permeability exhibited by displacement/ recovery test results. These intervals contain bedding-plane partings that appear to be present in all three boreholes. Multiple-well constant-discharge tests were conducted for each interval independently. To conduct the multiple-well constant-discharge test, the same permeable interval was isolated, using an inflatable packer above and below, in each of the three boreholes. Water was pumped from the isolated interval in one borehole at a constant rate using a down-hole Grundfos pump, and changes in water level were monitored in the isolated interval of all three bore- 


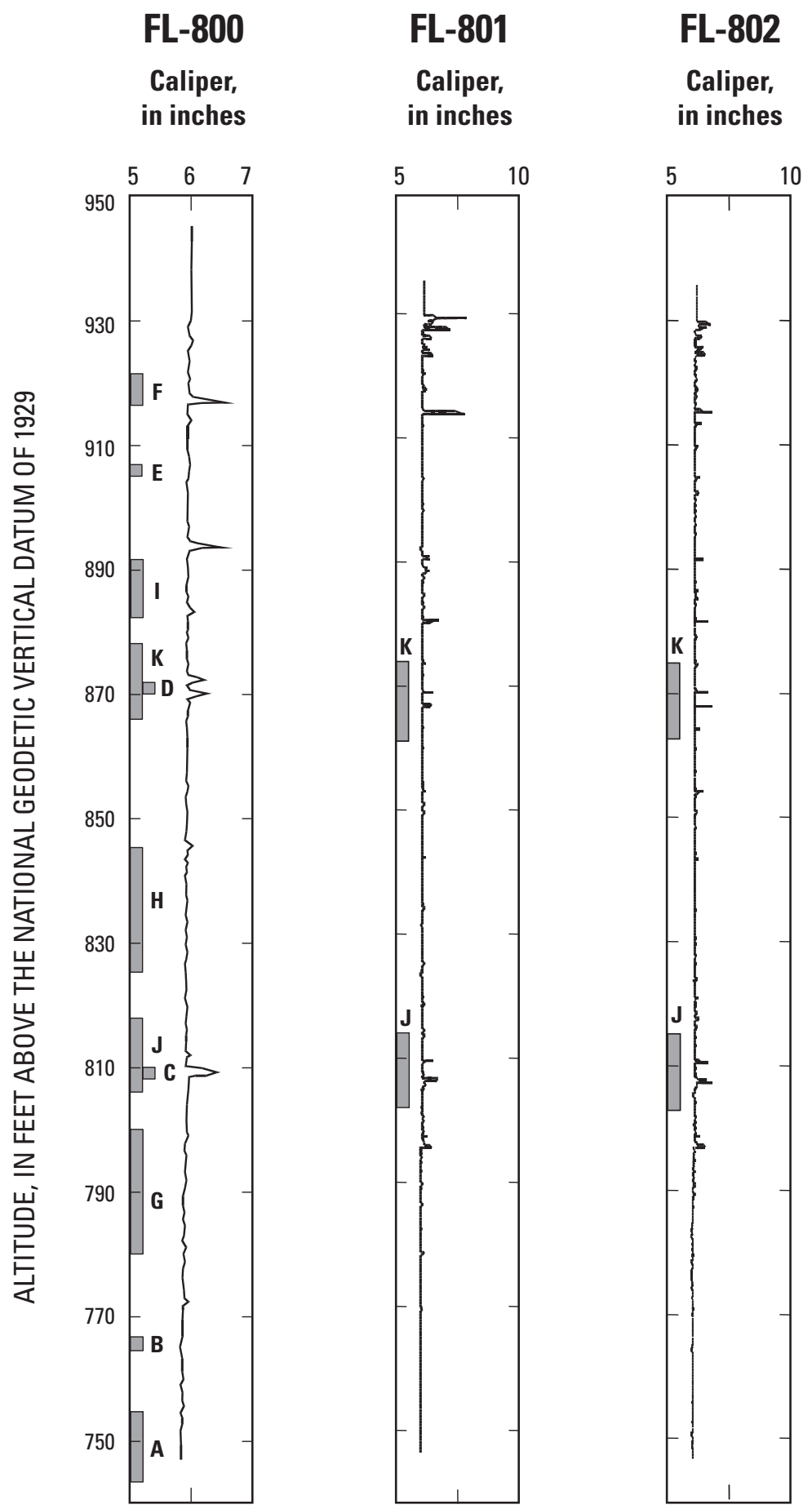

Figure 3. Intervals isolated by packers for boreholes FL-800, FL-801, and FL-802 at the study site in the vicinity of Waupun, Fond du Lac County, Wis. (Letters represent intervals selected for evaluation; datum for geophysical logs is top of casing; altitude at top of FL-800 casing is estimated to be $950 \mathrm{ft}$ above NGVD 29; survey level measurement shows altitude of FL-801 is $952.00 \mathrm{ft}$; of FL-802 is $950.10 \mathrm{ft})$. 
holes. Changes in water levels above and below the packed intervals were also monitored. The pump was moved to a second borehole, and the interval was pumped again, with water-level responses monitored in all the boreholes. The pump then was moved to the third borehole, and the procedure was repeated. The rate of pumping during the tests was set at about $4 \mathrm{gal} / \mathrm{min}$ for interval $\mathrm{K}$ (maximum rate of the pump) and about $2 \mathrm{gal} / \mathrm{min}$ for interval $\mathrm{J}$ (maximum rate that would not cause drawdown below the pump).

The transmissivity ( $\mathrm{T}$ ) of intervals $\mathrm{J}$ and $\mathrm{K}$ in each well bore was estimated using the Cooper and Jacobs (1946) straight-line method:

$$
\mathrm{T}=\frac{2.3 \mathrm{Q}}{4 \pi \mathrm{S}_{\log }}
$$

Where,

$$
\begin{aligned}
\mathrm{T}= & \text { transmissivity } \\
\mathrm{Q}= & \text { well discharge, and } \\
\mathrm{S}_{\log }= & \text { the measured rate of drawdown increase per } \\
& \text { common log cycle. }
\end{aligned}
$$

Estimated transmissivity was divided by the length of the isolated interval in the observed well to obtain an estimate of horizontal hydraulic conductivity.

$$
\mathrm{K}=\mathrm{T} / \mathrm{b}
$$

Where,

$\mathrm{K}=$ horizontal hydraulic conductivity,

$\mathrm{T}=$ transmissivity, and

$\mathrm{b}=$ length of the isolated interval.

An example of recent application of Cooper and Jacob straight-line method to aquifer tests in Sinnipee Group rocks can be found in Kay and others (2000).

\section{Water-Sample Collection}

Water samples collected from FL-800 and FL-802 during borehole development on April 8 and 9, 1996, were submitted for analysis of organic constituents to the USEPA Region 5 Central Regional Laboratory in Chicago, Illinois. Water samples collected during aquifer testing of selected intervals on April 24 and 25, 1996, were submitted for analysis of organic and inorganic constituents to the USEPA Region 5 Central Regional Laboratory in Chicago, Illinois, and for analysis of inorganic constituents and major ions to the USGS National Laboratory in Denver, Colorado. Sampling and analytical procedures were consistent with those outlined in the sampling and analysis plan (U.S. Environmental Protection Agency and U.S. Geological Survey, 1996). Field water-quality parameters ( $\mathrm{pH}$, water temperature, specific electrical conductance, and redox potential) were collected using a flow-throughcell connected directly to the pump discharge.

\section{Lithostratigraphy}

On the basis of the detailed description of rock core provided by the ISGS using nomenclature consistent with Conlon (1998), borehole FL-800 intersects (from oldest to youngest) the Glenwood Formation of the Ordovician Ancell Group and the dolomites of the Ordovician Sinnipee Group (fig. 4). Approximately $3 \mathrm{ft}$ of Glenwood Formation was recovered in the rock core and is described as a medium-grained, gray to brown sandstone. The Sinnipee Group at the site is about $183 \mathrm{ft}$ thick and consists of light-gray to medium-bluish-gray dolomite. A detailed lithologic description of all these units is presented in table 2.

The Sinnipee Group comprises three units. From oldest to youngest they are the Platteville Formation, the Decorah Formation, and the Galena Dolomite. The Platteville Formation is about $51 \mathrm{ft}$ thick and is massive dolomite that ranges in color from light brownish gray to very light pinkish gray. Three members are recognized in the Platteville Formation-Pecatonica, McGregor, and Quimby's Mill Members. The top of the Platteville Formation is marked by a well-developed hardground, indicating the presence of an unconformity separating the Platteville Formation from the overlying Decorah Formation. The Decorah Formation is about $14 \mathrm{ft}$ thick and composed of light gray to medium-light gray dolomite and shale. The dolomite to shale ratio of the Decorah Formation increases from 60:40 at its base to 95:5 at its top. The Galena Dolomite overlies the Decorah Formation and is about $119 \mathrm{ft}$ thick. The Galena Dolomite comprises two members-the Dunleith Dolomite and Wise Lake Members - and is generally an argillaceous dolomite with a wide range of grayish colors, including light gray, pinkish gray, and yellowish gray. Upward-fining sequences are common, with some terminating in hardgrounds; shale partings are common as well.

Geophysical logs for the three boreholes indicate that the nature of the Sinnipee Group is similar over the relatively short distance between boreholes (figs. 5, 6, and 7). Therefore, the following comparisons between geophysical logs for borehole FL-800 (fig. 5) and the descriptions and physical analysis of the rock core can be extrapolated to the other two boreholes. 
In general, there is good correlation between the geophysical logs and the physical description of the core. For instance, the described shale content of the Decorah Formation (table 2) is reflected on the natural-gamma log (fig. 5 ) as a zone of high gamma counts per second between 796 and $810 \mathrm{ft}$. The Galena Dolomite and Platteville For- mations, both described in core as more massive and less argillaceous, have relatively low gamma counts per second compared to the Decorah Formation. The shaley nature of the Decorah Formation also is reflected in lower resistance on the short-normal resistivity log (fig. 5).

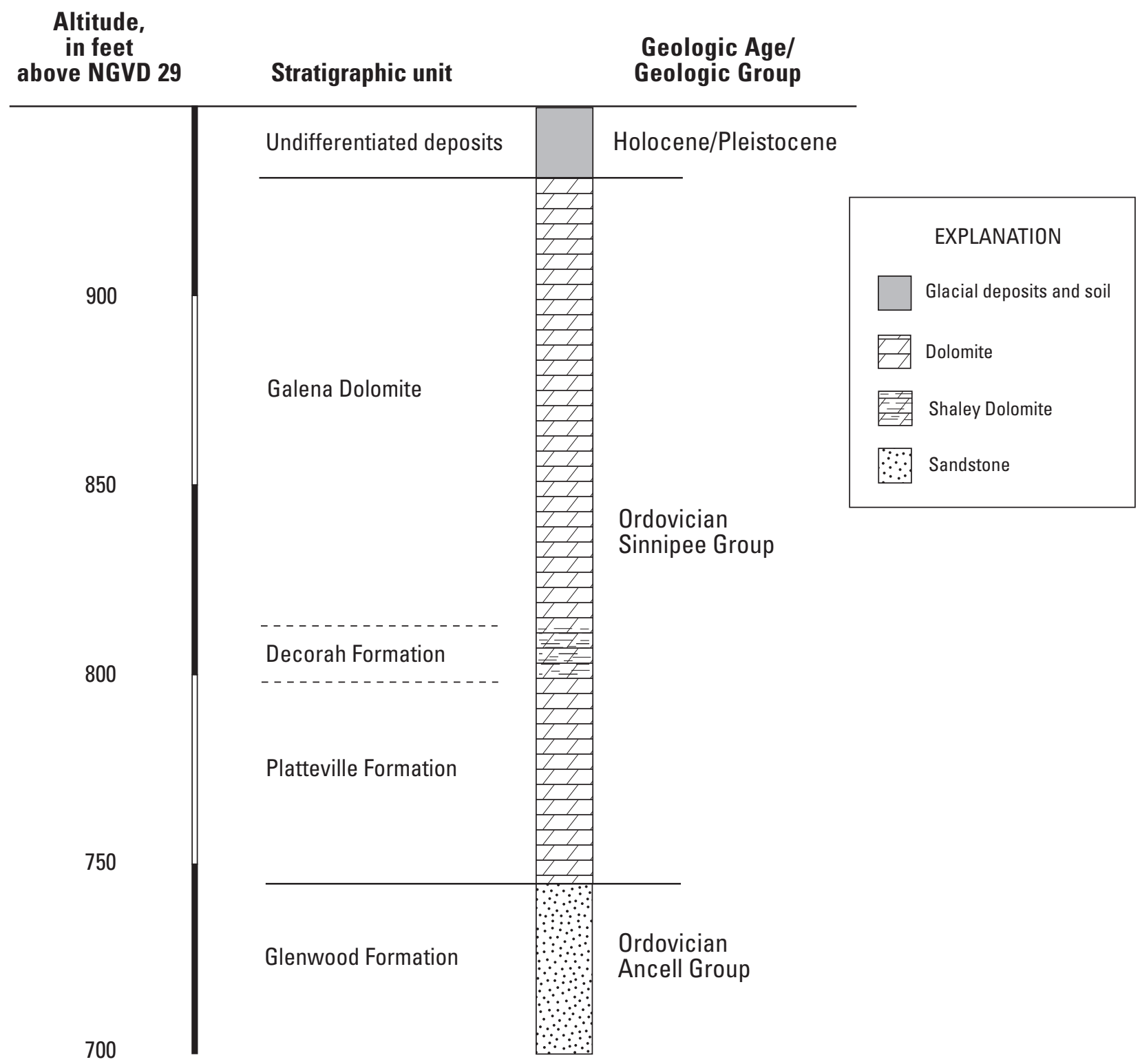

Figure 4. Generalized stratigraphy of the study site in the vicinity of Waupun, Fond du Lac County, Wis. (NGVD 29, National Geodetic Vertical Datum of 1929). 
Table 2. Abbreviated lithologic description and stratigraphic interpretation by the Illinois State Geological Survey of core from borehole FL-800 at the study site in the vicinity of Waupun, Fond du Lac County, Wis.

[Modified from Michael L. Sargent and Zakaria Lasemi, Illinois State Geological Survey, written commun.,1997; full description is available upon request from U.S. Geological Survey; datum is ground surface, estimated to be $949.00 \mathrm{ft}$ National Geodetic Vertical Datum of 1929 (NGVD 29); codes in parentheses are from the rock-color chart published by The Geological Society of America (1980)]

\begin{tabular}{|c|c|}
\hline $\begin{array}{c}\text { Altitude } \\
\text { (feet above NGVD 29) }\end{array}$ & Lithologic description of core and drill cuttings \\
\hline $929.50-949.00$ & Undifferentiated glacial deposits and soil, not described. \\
\hline $826.80-929.50$ & $\begin{array}{l}\text { Galena Dolomite-Wise Lake and Dunleith Dolomite Members - mostly pinkish gray to yellowish } \\
\text { gray ( } 5 \mathrm{Y} 8 / 1 \text { to } 5 \mathrm{Y} 8 / 1) \text {, from pinkish at the base }(826.80 \mathrm{ft} \text { ) they progressively become very slightly } \\
\text { more gray upward to } 852.85 \mathrm{ft} \text {. From } 852.85 \mathrm{ft} \text { upward to } 875.60 \mathrm{ft} \text { there are about seventeen upward- } \\
\text { fining cycles in which the rocks generally become more argillaceous and darker gray, some cycles then } \\
\text { terminate with a hard-ground that can range from medium gray to dark gray, (N5 to N3), overlying each } \\
\text { hard-ground is a lighter-colored pinkish-gray to yellowish-gray purer dolomite that sometimes contains } \\
\text { some olive-gray ( } 5 \mathrm{Y} 4 / 1) \text { shale partings and shadowy gray mottling; the gray zone, which is topped by } \\
\text { a hard-ground and ranges from } 852.85-854.50 \mathrm{ft} \text {, could be interpreted as the upper phase of a cycle for } \\
\text { which the underlying, purer dolomite phase extends from } 849.30-852.85 \mathrm{ft} \text {; the seventeen cycles range } \\
\text { from about } 0.4-2.0 \mathrm{ft} \text { thick. }\end{array}$ \\
\hline
\end{tabular}

823.30 - $826.80 \quad$ Galena Dolomite-Wise Lake and Dunleith Dolomite Members - nearly all pinkish gray (5 YR 8/1) with a little medium light gray to light gray mottling, mostly along styolites, as at 824.10 and 824.00 $\mathrm{ft}$; one weak very faint hard-ground marked by flat gray line in calcarenite at $826.30 \mathrm{ft}$; mostly medium grained and slightly porous, the more pure beds have spongy porosity and vugs up to about $0.5 \mathrm{ft}$ across, some vugginess seems to be fossil moldic; Hormatoma-like fossil mold at $826.50 \mathrm{ft}$, fracturing in the interval at $826.00-825.60 \mathrm{ft}$ appears to be mechanical.

810.90 - $823.30 \quad$ Galena Dolomite-Wise Lake and Dunleith Dolomite Members - mostly pinkish gray to yellowish gray (5 Y 8/1 to 5 Y 8/1) slightly argillaceous dolomite interbedded and interlaminated with olive gray to brownish gray (5 Y 4/1 to 5 YR 4/1) paper-thin wavy-bedded shales (3-5\%). Several distinct beds of light gray to very light gray (N7 to N8) slightly vuggy to vuggy dark-gray specked calcarenite beds 0.5-3.0 ft thick. The less argillaceous they are, the lighter their color and more vuggy they appear. These beds are medium to coarsely crystalline; most of this interval is fine- to medium-crystalline dense dolomite. Some beds are medium to coarsely crystalline and porous to vuggy, these coarser beds are quite pure dolomite and generally grade upward into finer more argillaceous and shaley dolomite.

797.20 - $810.90 \quad$ Decorah Formation-Spechts Ferry Shale - Dolomite and shale and intermixtures of these two, dolomite ranges from light gray to medium-light gray (N7 to N6) with much darker gray very fine "salt and pepper" speckling, very light gray to white (N8 to N9) dolomitized bryzoan fossils; shales range from grayish olive green to dark greenish gray ( $5 \mathrm{GY} 3 / 2$ to $5 \mathrm{GY} 4 / 1$ ); dolomite is predominately mediumgrained calcarenite. Overall the formation grades upward from a 60:40 dolomite to shale ratio at the base to at least $95 \%$ dolomite at the top. Within this 13.7 -ft-thick upward-increasing carbonate cycle there are several second-order cycles that begin with a relatively flat bottomed carbonate phase and grade upward into a shale mixed with dark-gray-speckled nodular-dolomite phase.

769.30 - 797.20 Platteville Formation—Quimby's Mill Member - Dolomite, virtually all light brownish gray (5YR 7/1), the upper foot is very light olive gray mottled with olive gray (5Y 7/1 with 5Y 5/1); burrow mottling of light gray to medium light gray (N7 to N6) is most prominent in zone from 794.50-789.00 ft and at the base of the unit, 770.50-769.30 ft. A very prominent well-developed hard-ground at the top of the Platteville Formation indicates that the Decorah Formation unconformably overlies the Platteville Formation.

753.80 - $769.30 \quad$ Platteville Formation-McGregor Member; Dolomite, 95\% fine-grained dolomite that is very light pinkish gray (5YR 7/1) streaked with argillaceous and shaley beds that range from light olive gray to olive gray ( 5 Y $6 / 1$ to $5 \mathrm{Y} 4 / 1$ ); the several calcarenite beds, which range from $0.5-2$ inches thick, range from medium light gray to very light gray to pinkish gray (N6 to N8 to 5YR 8/1) and generally show mottling and speckling of tones as dark as dark gray (N3). 
Table 2. Abbreviated lithologic description and stratigraphic interpretation by the Illinois State Geological Survey of core from borehole FL-800 at the study site in the vicinity of Waupun, Fond du Lac County, Wis. - Continued.

[Modified from Michael L. Sargent and Zakaria Lasemi, Illinois State Geological Survey, written commun.,1997; full description is available upon request from U.S. Geological Survey; datum is ground surface, estimated to be $949.00 \mathrm{ft}$ National Geodetic Vertical Datum of 1929 (NGVD 29); codes in parentheses are from the rock-color chart published by The Geological Society of America (1980)]

\begin{tabular}{cc}
$\begin{array}{c}\text { Altitude } \\
\text { (feet above NGVD 29) }\end{array}$ & Lithologic description of core and drill cuttings \\
\hline $746.20-753.80$ & $\begin{array}{c}\text { Platteville Formation-Pecatonica Member; Dolomite, mostly very light brownish gray (5 YR 7/1), in } \\
\text { the basal foot becoming mottled on a background of light gray to yellowish gray (N7 to 5Y 8/1), also } \\
\text { some medium light gray to medium dark gray (N6 to N4) mottling in the lower part above the basal foot; } \\
\text { becomes less sharp and lighter toward the top; the top foot has very little mottling except in the top one } \\
\text { inch, which is dark gray around the edges, this zone carries on the well-developed hard-ground at the top } \\
\text { of the member. } \\
\text { Ancell Group-Glenwood Formation; Sandstone, light gray to very light gray (N7 to N8) "salt and pep- } \\
\text { per" near top (approximately upper 2 ft) becoming more light gray streaked on light gray toward bottom } \\
\text { of the core. The top 2-inch section of core is light gray horizontally streaked with much darker tones of } \\
\text { grayish black to olive black (N2 to 5Y 2/1), this 2-ft section also contains pebble and smaller clasts rang- } \\
\text { ing from pinkish brown (10 YR 7/4 to 10 YR 5/4), many of these clasts are mantled with pyrite cement } \\
\text { in the surrounding sandstone of a much thinner black mantle. }\end{array}$ \\
\hline
\end{tabular}



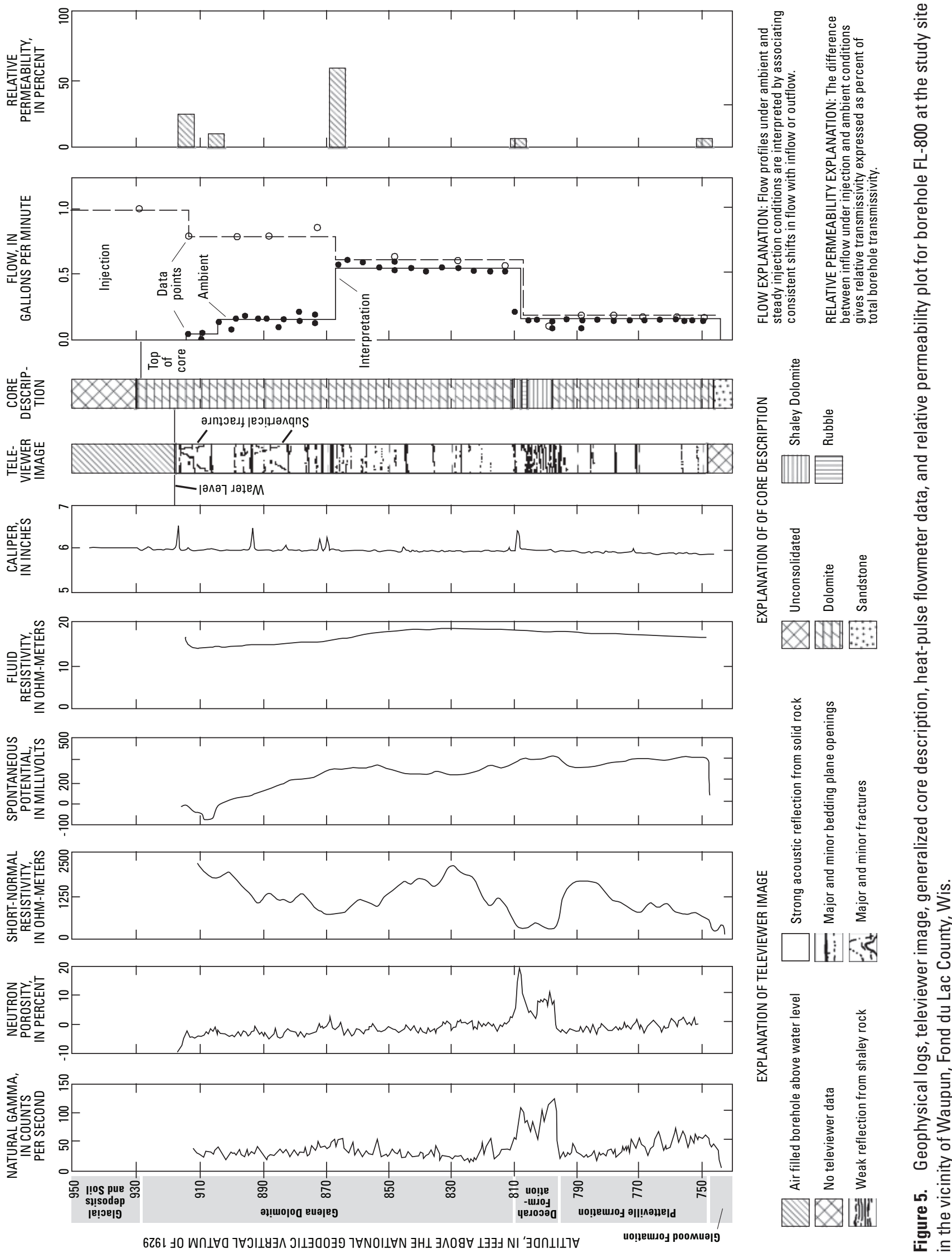

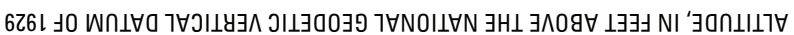

ио!̣ешдㅇ роомиәэ
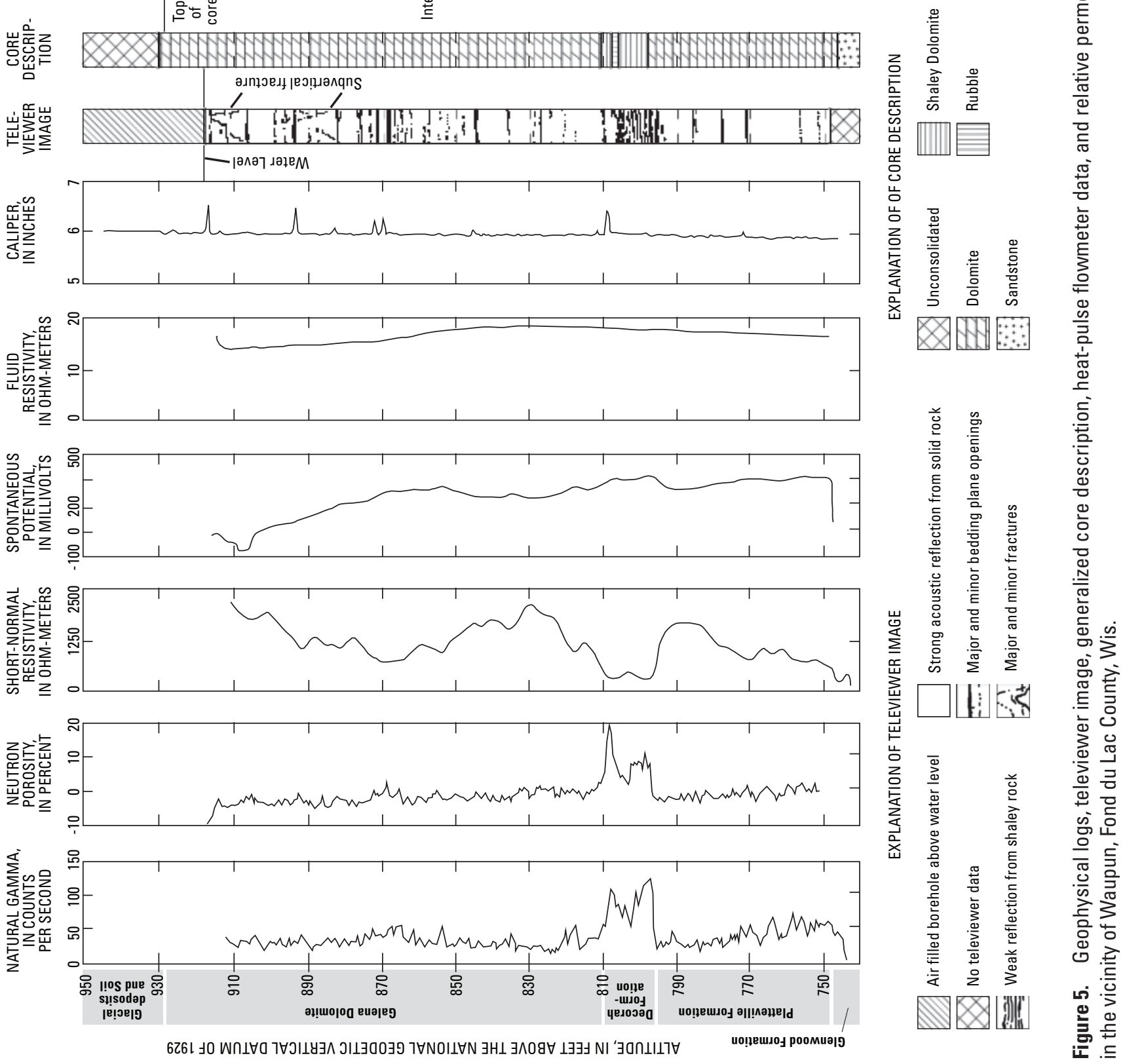

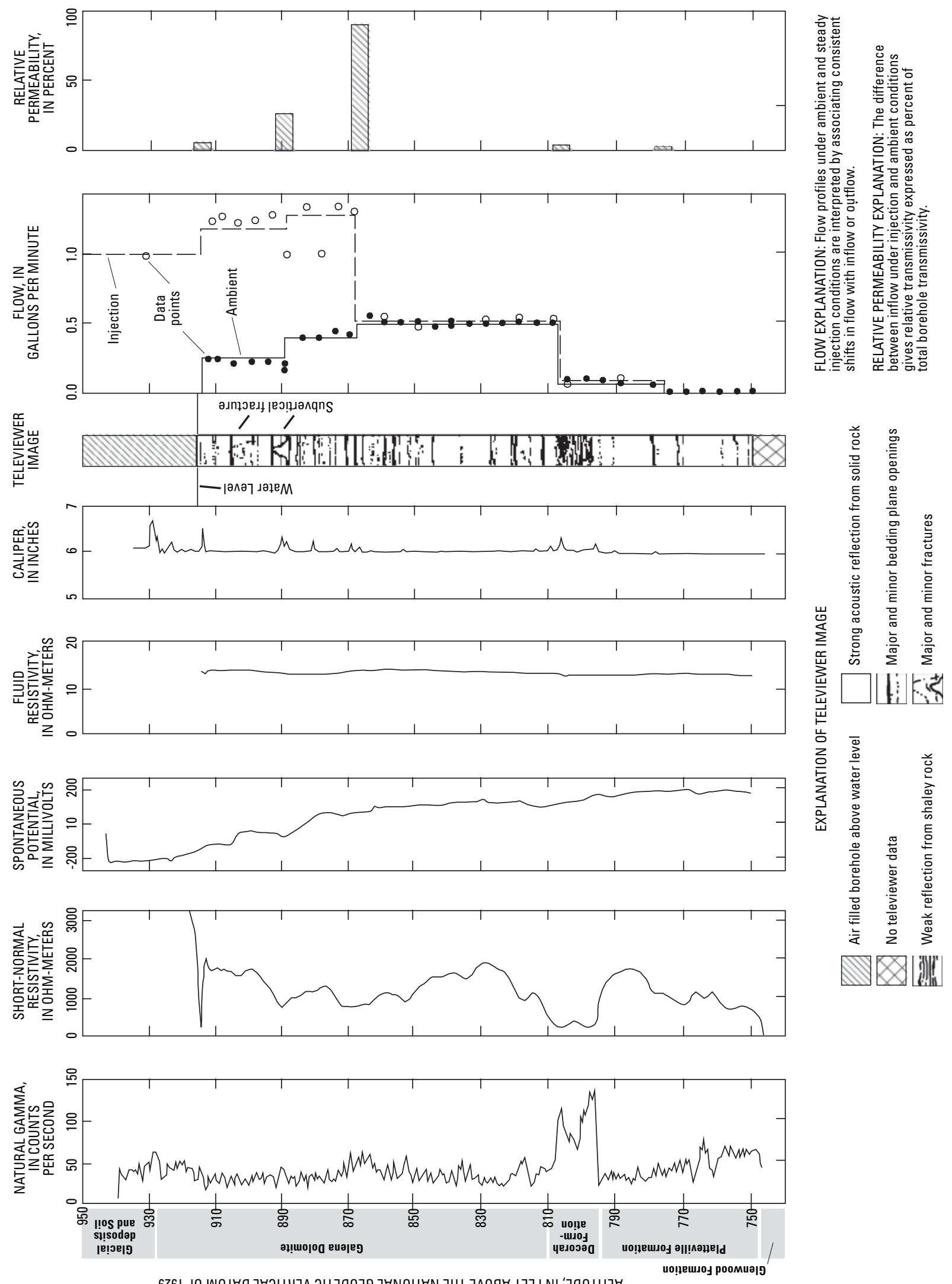

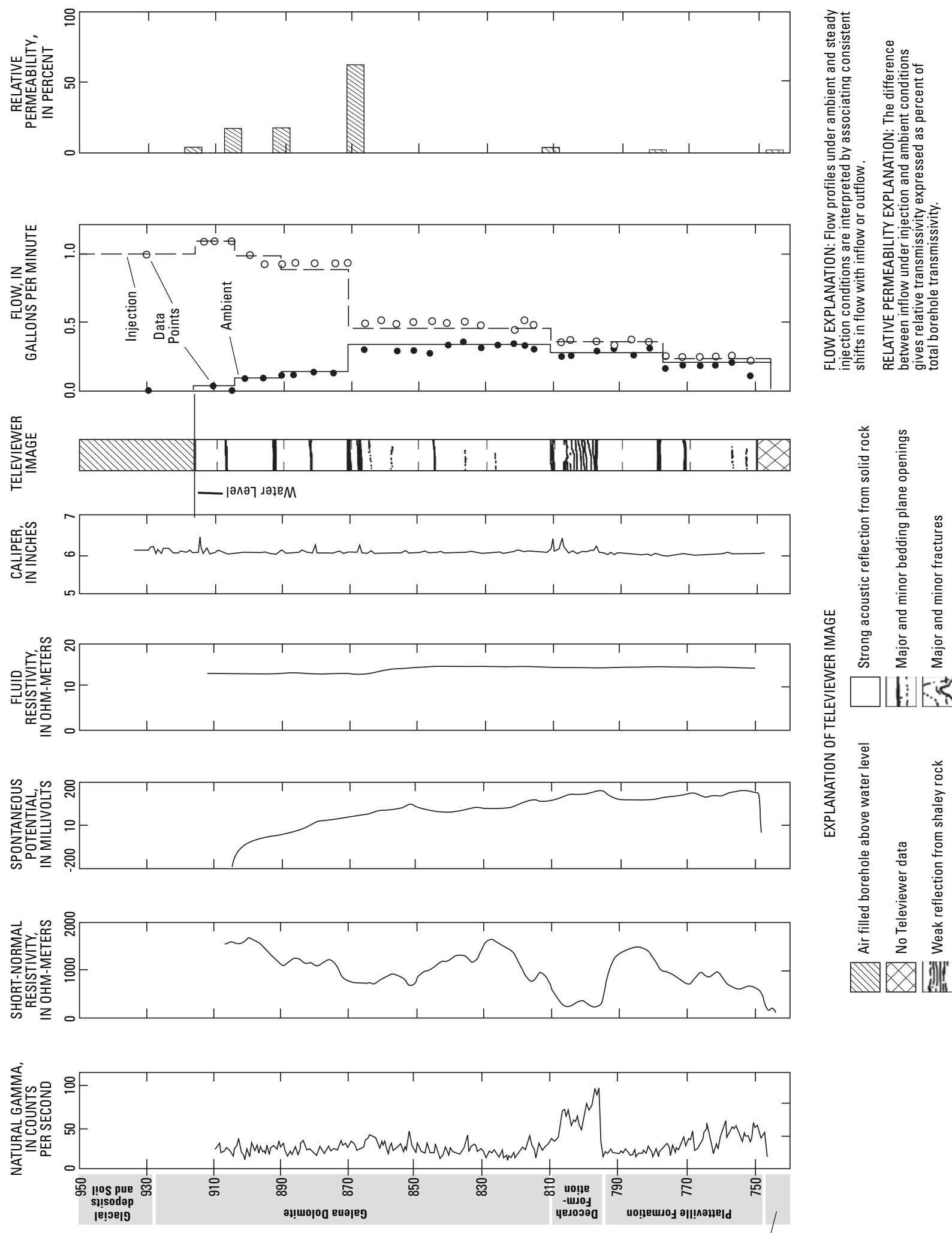

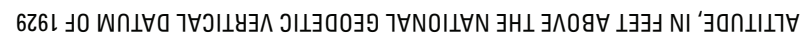

นо!̣ешдоง роомиәэ

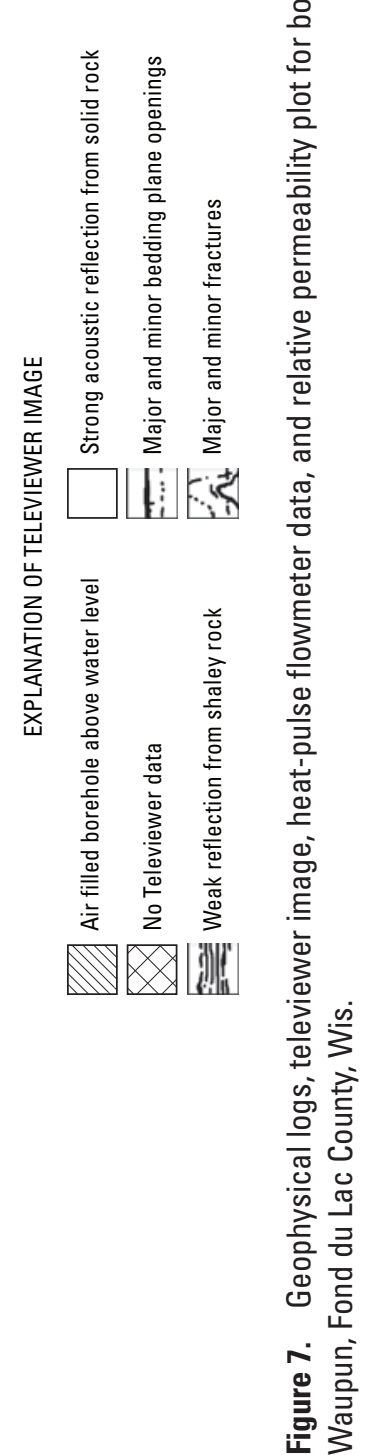




\section{Hydrogeological Characteristics}

The hydrogeologic characteristics of the Sinnipee Group in the vicinity of Waupun are interpreted from the collected data. Measurement of rock-matrix properties provides a fundamental assessment of hydrogeological properties, the chemistry of water sampled from the boreholes reflects aquifer lithology, and comparison of the physical description of the rock core and geophysical data allows a broader interpretation of the local hydrogeologic characteristics of the Sinnipee Group.

\section{Rock-Matrix Properties}

Seven samples of the Galena Dolomite, two samples of the Decorah Formation, six samples of the Platteville Formation, and two samples of the Glenwood Formation were analyzed by hydrologists at the USGS Illinois Water Science Center for selected rock-matrix properties (table 3 ). The chosen samples did not have obvious development of secondary permeability. The greatest measured porosity is 14.6 percent in the Glenwood Formation; this porosity falls in the middle of the range of porosity for sandstones (Freeze and Cherry, 1979). Among the Sinnipee Group samples, porosity values ranged from 1.6 percent at the top of the Galena Dolomite to 9.7 percent in the Decorah Formation. The mean porosity of the two Decorah Formation samples is 8.3 percent, of the seven Galena Dolomite samples is about 2.4 percent, and of the six Platteville Formation samples is 3.6 percent. On the basis of this limited number of samples, it appears that the Decorah Formation has higher matrix porosity than either the Galena Dolomite or the Platteville Formation (table 3). The relatively low porosity of the Galena Dolomite and Platteville Formation appears due to the overall massive crystalline nature of the dolomites in these units.

No substantial difference is apparent in either the bulk or grain densities in samples of the three Sinnipee Group units. Bulk density ranges from 2.4 to $2.8 \mathrm{~g} / \mathrm{cm}^{3}$. Grain density ranges from 2.5 to $2.9 \mathrm{~g} / \mathrm{cm}^{3}$ (table 3 ), the higher of which is a typical value for pure dolomite (Hurlbut and Klein, 1977, p. 308).

Table 3. Physical properties of selected rock core intervals from borehole FL-800 at the study site in the vicinity of Waupun, Fond du Lac County, Wis.

[analyses conducted by the USGS Illinois Water Science Center; datum is land surface, estimated to be 949.00 feet above National Vertical Geodetic Datum of 1929 (NVGD 29)]

\begin{tabular}{|c|c|c|c|c|}
\hline Stratigraphic Interval & $\begin{array}{c}\text { Core interval } \\
\text { (feet above NGVD 29) }\end{array}$ & $\begin{array}{l}\text { Porosity } \\
\text { (percent) }\end{array}$ & $\begin{array}{c}\text { Bulk density } \\
\text { (grams per cubic centimeter) }\end{array}$ & $\begin{array}{c}\text { Grain density } \\
\text { (grams per cubic centimeter) }\end{array}$ \\
\hline \multirow[t]{7}{*}{ Galena Dolomite } & $927.70-927.95$ & 1.6 & 2.8 & 2.9 \\
\hline & $905.30-905.70$ & 1.9 & 2.4 & 2.5 \\
\hline & $868.40-868.80$ & 2.1 & 2.8 & 2.9 \\
\hline & $851.05-851.30$ & 3.2 & 2.8 & 2.9 \\
\hline & $829.05-829.30$ & 1.7 & 2.7 & 2.7 \\
\hline & $824.45-824.70$ & 3.8 & 2.7 & 2.8 \\
\hline & $812.85-813.10$ & 2.3 & 2.8 & 2.8 \\
\hline \multirow[t]{2}{*}{ Decorah Formation } & $806.00-806.45$ & 6.9 & 2.6 & 2.7 \\
\hline & $798.05-798.40$ & 9.7 & 2.5 & 2.8 \\
\hline \multirow[t]{6}{*}{ Platteville Formation } & $793.44-793.60$ & 1.8 & 2.8 & 2.8 \\
\hline & $784.75-785.05$ & 3.7 & 2.7 & 2.8 \\
\hline & $770.55-770.85$ & 4.0 & 2.7 & 2.8 \\
\hline & $764.00-764.80$ & 4.3 & 2.7 & 2.8 \\
\hline & $753.80-754.10$ & 4.1 & 2.7 & 2.8 \\
\hline & $746.50-746.80$ & 3.7 & 2.7 & 2.8 \\
\hline \multirow[t]{2}{*}{ Glenwood Formation } & $745.70-746.20$ & 3.0 & 2.7 & 2.8 \\
\hline & $743.65-743.90$ & 14.6 & 2.3 & 2.6 \\
\hline
\end{tabular}


Lithostratigraphic and Hydrogeologic Characteristics of the Ordovician Sinnipee Group in the Vicinity of Waupun, Wis.

The higher measured porosity of the Decorah Formation compared to the rest of the Sinnipee Group (table 3) is reflected in the neutron-porosity log (fig. 5). The maximum neutron-porosity data (limestone calibration) indicate an apparent porosity of 10 to 20 percent in the shaley interval from 798 to $810 \mathrm{ft}$. Analysis of two core samples from the Decorah Formation provided porosity values of 6.9 and 9.7 percent. This is in contrast to the range of measured porosity of 1.6 to 4.3 percent for the rest of the Sinnipee Group. Assuming that pure shale would have an apparent porosity of about 30 percent (on the basis of log response in other areas), this means the maximum shale fraction is 30 to 60 percent, and probably averages 15 to 20 percent in this interval (Paillet and Crowder, 1996; Paillet, 1994). Neutron logging was performed in FL-800 only.

Except for the shaley interval from 798 to $810 \mathrm{ft}$ mentioned above, the neutron log of borehole FL-800 (calibrated for limestone porosity) shows porosity values of -4 to -2 percent. Quartz lithology correction to neutron porosity logs gives about a +4 percent correction, whereas the dolomite lithology correction is about -5 percent for a nominal limestone calibrated value of 0 . The small negative values for porosity in the -4 to 0 percent range indicate the presence of substantial quartz (possibly chert) in the dolomite (Paillet and Crowder, 1996; Paillet, 1994).

Radar-propagation velocity and radar-wave attenuation tomograms produced from the FL-800 to FL-802 cross-borehole data (figs. 8a and b) indicate the average velocity of $60-\mathrm{MHz}$ radar waves at the site is about 305 feet per microsecond (95 meters per microsecond), and the average attenuation of radar waves is about 6.7 decibels per foot (21 decibels per meter). There is an inverse relation between velocity and attenuation at this site, consistent with the results of many other cross-borehole radar tomography studies. The decrease in radar-propagation velocity and the increase in radar-wave attenuation has been associated with, and is theoretically consistent with, increased water content and electomagnetic-wave attenuation due to the presence of high-porosity, electrically conductive rocks (Lane and others, 1994; Singha and others, 2000; Williams and Lane, 1998).

The cross-borehole radar tomography data show differences in velocity and attenuation (fig. 8) among the three major units in the Sinnipee Group. Matrix porosity measured in rock-core samples (table 3) correlates well with these velocity and attenuation tomograms. The Galena Dolomite has the lowest mean porosity at 2.4 percent and is represented in the tomograms as generally having the lowest attenuation and greatest velocity. Below the Galena Dolomite is a transition to a zone with the greatest attenuation and lowest velocity on the tomogram (fig. 8). The rock core shows this interval (about 796 to $815 \mathrm{ft}$ ) to be the shaley dolomite of the Decorah Formation which has the greatest measured porosity of samples analyzed in the core-a mean porosity of 8.3 percent. Below the Decorah Formation, the Platteville Formation has a mean porosity of 3.6 percent and is represented in the tomograms as having velocity and attenuation generally intermediate between the Galena Dolomite and the Decorah Formation.

Two limitations were experienced with this cross-hole radar data collection. First, the density of the data was less than desired, limited as a result of logistical and equipment problems. Second, deviation logs were not run in boreholes FL-800 and FL-802, so borehole deviation is not known. Deviation information would provide more detail in locating the transmitter and receiver in each borehole. Assuming that boreholes are vertical usually is not a safe assumption, but the lack of deviation data does not appear to have an important effect on the interpretation in this case (John Lane, U.S. Geological Survey, written commun., 1999).

\section{Water Type and Chemical Characteristics}

Water-quality analyses were conducted for samples collected from FL-800 and FL-802. Samples were collected from both boreholes on April 8 and 9, 1996, immediately prior to the cessation of pumping during borehole development, and on April 24 and 25, 1996, from four packed intervals in FL-800 only. The intervals from shallowest to deepest are interval F (917 to $922.5 \mathrm{ft}$ ), interval E (905 to $907 \mathrm{ft}$ ), interval D (870 to $872 \mathrm{ft}$ ), and interval C (808 to $810 \mathrm{ft}$ ).

A single packer at $917 \mathrm{ft}$ defined interval $\mathrm{F}$, with the tested interval extending to the water table at $922.5 \mathrm{ft}$ (fig. 3). When sampling interval $F$, the packed interval was pumped dry after approximately 18 minutes of pumping. The interval was allowed to recover for approximately 30 minutes, and then pumped again. Sample volumes recovered were sufficient for analysis of organic constituents and trace elements; however, the interval was pumped dry again with only enough water collected for analysis for some inorganic constituents. Therefore, interval $F$ of borehole FL-800 could not be evaluated properly for water type.

The other sampled intervals, C, D, and E, were isolated by a packer on either side of a 2-foot screen. Intervals $C$ and $D$ are shorter packed intervals that fall within intervals J and K of FL-800, respectively (fig. 3). Results of analysis for inorganic constituents, trace elements, and 
a)

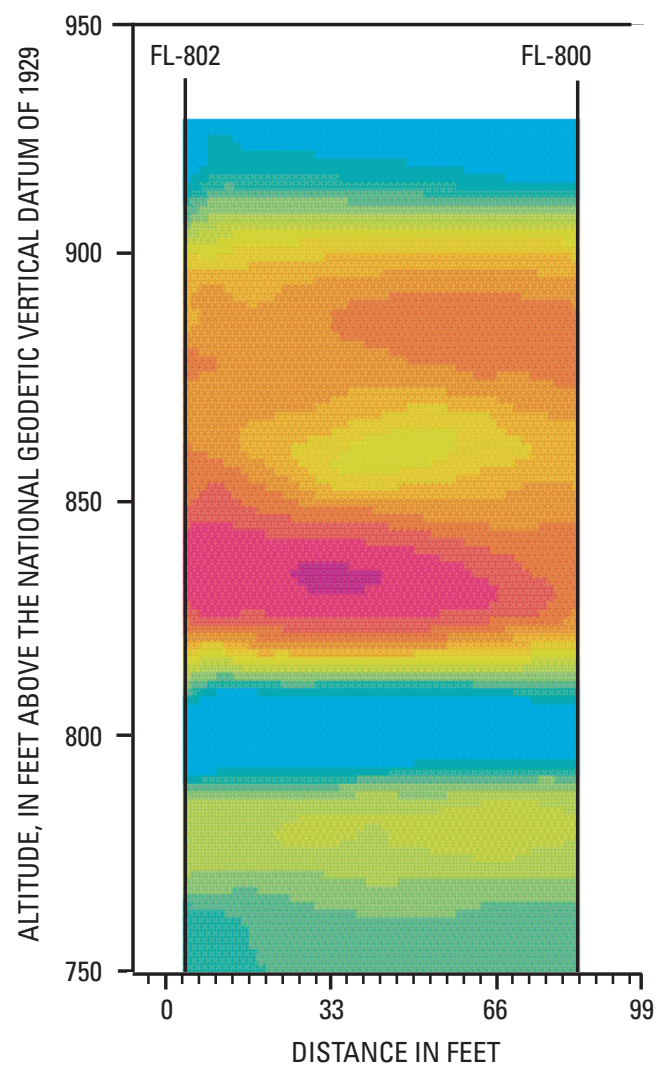

Attenuation tomogram for the study site, Waupun, Wis.

EXPLANATION

Attenuation,

in decibels per meter

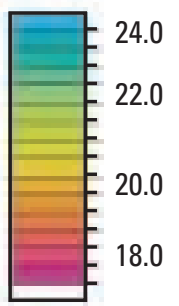

b)

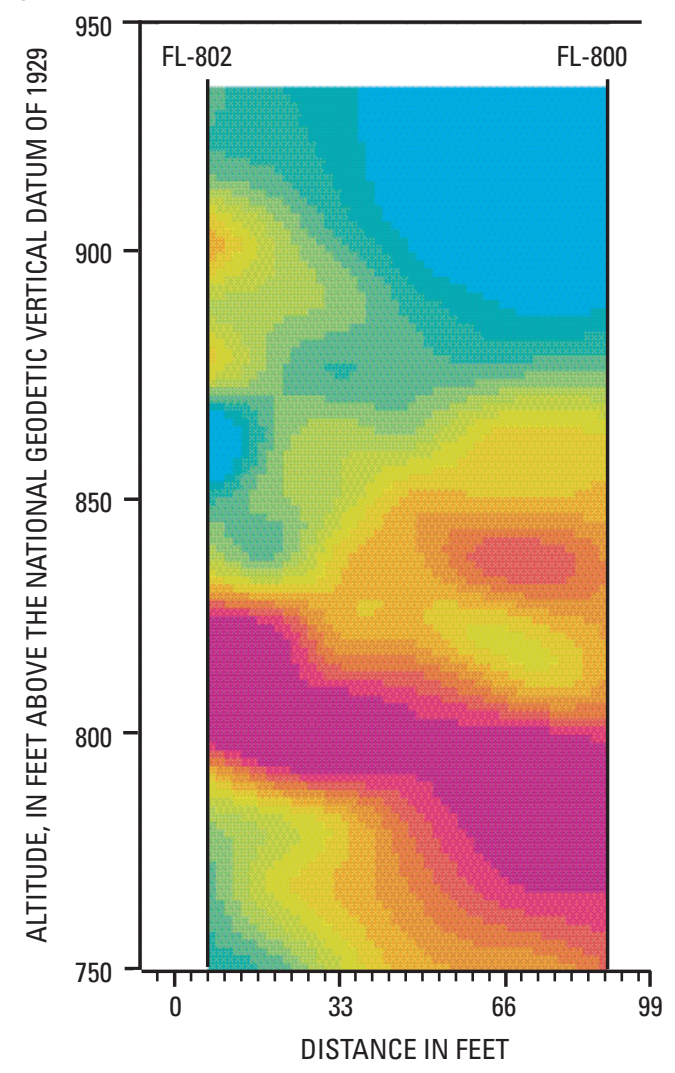

Velocity tomogram for the study site, Waupun, Wis.

\section{EXPLANATION}

Velocity, in meters per microsecond

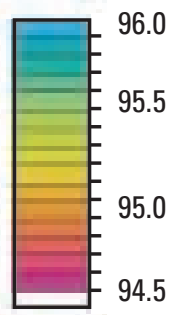

Figure 8. Attenuation tomagram (a) and velocity tomagram (b) from cross-borehole radar data collected between boreholes FL800 and FL-802 at the study site in the vicinity of Waupun, Fond du Lac County, Wis. 
major ions in samples collected from the four intervals are presented in tables 4 and 5; results for organic constituents are presented in table 6 .

The hydrogeochemical classification of the water types from intervals C, D, and E were determined using Piper diagrams (fig. 9) and found to be calcium-magnesium bicarbonate type waters. The occurrence of this water type is believed to be due to the carbonate-rich minerals in the Ordovician aquifer and the generally short flow paths within the aquifer (Olcott, 1992); these findings are consis- tent with previous interpretations of water-quality data in Wisconsin (Kammerer, 1984; Saad, 1996). The ion balance indicated by analysis of water from interval $F$ was a departure from that of the other intervals, believed to be due to the fact that interval $F$ was pumped dry during sampling.

Except for one sample containing trichloroethene (1 microgram per liter) that was collected during borehole development of FL-800 (table 6), all of the organic compounds detected were estimated or quantified due to presence in a laboratory blank. Results of analyses for

Table 4. Results of analyses for trace elements, major ions, and physical properties in water samples collected from intervals F, E, D, and C in borehole FL-800 on April 24 and 25, 1996, at the study site in the vicinity of Waupun, Fond du Lac County, Wis.

[MCL, maximum contaminant level; - -, no established MCL; - , not analyzed; ND, not determined; mg/L, milligrams per liter; $\mathrm{CaCO}_{3}$, calcium carbonate; $\mu \mathrm{g} / \mathrm{L}$, micrograms per liter; $\mu \mathrm{S} / \mathrm{cm}$, microsiemens per centimeter; ${ }^{\circ} \mathrm{C}$, degrees Celsius; analyses were conducted by U.S. Geological Survey laboratory in Denver, Colo.; altitude of packed intervals defined in table 3; intervals depicted in figure 3]

\begin{tabular}{|c|c|c|c|c|c|c|}
\hline Constituent & $M^{\prime} L^{a}$ & Units & $\begin{array}{c}\text { FL-800 } \\
\text { Interval F }\end{array}$ & $\begin{array}{c}\text { FL-800 } \\
\text { Interval E }\end{array}$ & $\begin{array}{c}\text { FL-800 } \\
\text { Interval D }\end{array}$ & $\begin{array}{c}\text { FL-800 } \\
\text { Interval C }\end{array}$ \\
\hline $\mathrm{pH}$ & & standard units & 7.67 & 7.4 & 7.4 & 7.2 \\
\hline Hardness, total & -- & $\mathrm{mg} / \mathrm{L}$ as $\mathrm{CaCO}_{3}$ & - & 610 & 570 & 640 \\
\hline Calcium $(\mathrm{Ca})$, dissolved & - & $\mathrm{mg} / \mathrm{L}$ as $\mathrm{Ca}$ & - & 130 & 120 & 130 \\
\hline Magnesium (Mg), dissolved & -- & $\mathrm{mg} / \mathrm{L}$ as $\mathrm{Mg}$ & - & 70 & 66 & 76 \\
\hline Sodium (Na), dissolved & - & $\mathrm{mg} / \mathrm{L}$ as $\mathrm{Na}$ & - & 10 & 15 & 17 \\
\hline Sodium adsorption ratio & - & ratio & - & 0.2 & 0.3 & 0.3 \\
\hline Sodium, percent & -- & percent & - & 4 & 6 & 6 \\
\hline Potassium (K), dissolved & -- & $\mathrm{mg} / \mathrm{L}$ as $\mathrm{K}$ & - & 5.5 & 15 & 31 \\
\hline Chloride $(\mathrm{Cl})$, dissolved & -- & $\mathrm{mg} / \mathrm{L}$ as $\mathrm{Cl}$ & 190 & 81 & 95 & 130 \\
\hline Sulfate $\left(\mathrm{SO}_{4}\right)$, dissolved & -- & $\mathrm{mg} / \mathrm{L}$ as $\mathrm{SO}_{4}$ & 110 & 120 & 140 & 150 \\
\hline Fluoride $(\mathrm{F})$, dissolved & -- & $\mathrm{mg} / \mathrm{L}$ as $\mathrm{F}$ & .1 & .2 & .2 & .2 \\
\hline Silica $\left(\mathrm{SiO}_{2}\right)$, dissolved & -- & $\mathrm{mg} / \mathrm{L}$ as $\mathrm{SiO}_{2}$ & 19 & 15 & 13 & 14 \\
\hline Iron $(\mathrm{Fe})$, dissolved & 300 & $\mu \mathrm{g} / \mathrm{L}$ as $\mathrm{Fe}$ & 25 & 190 & 330 & 250 \\
\hline Manganese (Mn), dissolved & 50 & $\mu \mathrm{g} / \mathrm{L}$ as $\mathrm{Mn}$ & 140 & 34 & 74 & 93 \\
\hline Residue, dissolved $180^{\circ} \mathrm{C}$ & -- & $\mathrm{mg} / \mathrm{L}^{\mathrm{b}}$ & 1,080 & 700 & 692 & 884 \\
\hline Dissolved solids, sum & -- & $\mathrm{mg} / \mathrm{L}^{\mathrm{b}}$ & ND & 665 & 672 & 796 \\
\hline Bromide $(\mathrm{Br})$, dissolved & -- & $\mathrm{mg} / \mathrm{L}$ as $\mathrm{Br}$ & 0.06 & 0.1 & 0.09 & 0.11 \\
\hline Specific conductance & -- & $\mu \mathrm{S} / \mathrm{cm}$ & 1,490 & 1,110 & 1,130 & 1,400 \\
\hline Alkalinity as $\mathrm{CaCO}_{3}$ & -- & $\mathrm{mg} / \mathrm{L}$ as $\mathrm{CaCO}_{3}$ & 317 & 388 & 345 & 412 \\
\hline Ion balance & - - & percent difference & ND & 1.14 & -0.09 & -2.53 \\
\hline
\end{tabular}

${ }^{\text {a }}$ Secondary Drinking Water Standard (U.S. Environmental Protection Agency, 2000).

${ }^{\mathrm{b}}$ For the purposes of this report, concentrations reported in milligrams per liter (mg/L) are equivalent to parts per million (ppm). 
inorganic constituents indicate that the USEPA Primary Drinking Water Standard for antimony was exceeded in a sample collected from interval D (table 5). Water collected from interval F exceeded the USEPA Secondary Drinking Water Standard for aluminum and the USEPA Drinking Water Equivalent Level for sodium (table 5). Concentra- tions of iron in samples collected from all four tested intervals exceeded the USEPA Secondary Drinking Water Standard (table 5), and all concentrations of manganese and dissolved manganese were near or exceeded the USEPA Secondary Drinking Water Standard (tables 4 and 5).

Table 5. Results of analyses for inorganic constituents in water samples collected from intervals $F, E, D$, and $C$ in borehole FL-800 on April 24 and 25, 1996, at the study site in the vicinity of Waupun, Fond du Lac County, Wis.

[all values reported in micrograms per liter; MCL, maximum contaminant level; --, no established MCL; <, less than the indicated detection limit; analyses were conducted by U.S. Environmental Protection Agency Central Regional Laboratory in Chicago, Illinois; altitude of packed intervals defined in table 4]

\begin{tabular}{|c|c|c|c|c|c|}
\hline Constituent & MCL & $\begin{array}{c}\text { FL-800 } \\
\text { Interval F }\end{array}$ & $\begin{array}{c}\text { FL-800 } \\
\text { Interval E }\end{array}$ & $\begin{array}{c}\text { FL-800 } \\
\text { Interval D }\end{array}$ & $\begin{array}{c}\text { FL-800 } \\
\text { Interval C }\end{array}$ \\
\hline Aluminum & $50-200^{\mathrm{a}}$ & 272 & $<80$ & $<80$ & $<80$ \\
\hline Antimony & $6^{\mathrm{b}}$ & 1 & 2 & 21 & 9 \\
\hline Arsenic & $50^{\mathrm{b}}$ & $<2$ & 4.1 & 5.1 & $<2$ \\
\hline Barium & $2,000^{\mathrm{b}}$ & 208 & 175 & 209 & 216 \\
\hline Beryllium & $4^{b}$ & $<1$ & $<1$ & $<1$ & $<1$ \\
\hline Cadmium & $5^{b}$ & $<0.2$ & $<0.2$ & $<0.2$ & $<0.2$ \\
\hline Calcium & - & 145,000 & 129,000 & 122,000 & 140,000 \\
\hline Chromium & $100^{\mathrm{b}}$ & $<8$ & $<8$ & $<8$ & $<8$ \\
\hline Cobalt & - & $<6$ & $<6$ & $<6$ & $<6$ \\
\hline Copper & $1,000^{\mathrm{a}}$ & 48.7 & 43.2 & $<6$ & $<6$ \\
\hline Iron & $300^{\mathrm{a}}$ & 778 & 456 & 775 & 432 \\
\hline Lead & $15^{\mathrm{b}}$ & 5 & $<2$ & 2 & $<4$ \\
\hline Magnesium & - & 87,900 & 68,000 & 65,200 & 77,100 \\
\hline Manganese & $50^{\mathrm{a}}$ & 149 & 40.9 & 88.2 & 108 \\
\hline Nickel & $100^{\mathrm{b}}$ & 33.8 & 74.4 & 37.4 & 35.2 \\
\hline Potassium & - & 99,200 & 8780 & 18,700 & 36,900 \\
\hline Selenium & $50^{\mathrm{b}}$ & $<2$ & $<2$ & $<2$ & $<2$ \\
\hline Silver & $100^{\mathrm{a}}$ & $<6$ & $<6$ & $<6$ & $<6$ \\
\hline Sodium & $20,000^{\mathrm{c}}$ & 25,400 & 10,700 & 15,500 & 18,000 \\
\hline Thallium & $2^{\mathrm{b}}$ & $<2$ & $<2$ & $<2$ & $<2$ \\
\hline Vanadium & - & $<5$ & $<5$ & $<5$ & $<5$ \\
\hline Zinc & $5,000^{\mathrm{a}}$ & 43.6 & $<40$ & 56.4 & 307 \\
\hline
\end{tabular}

${ }^{a}$ Secondary Drinking Water Standard (U.S. Environmental Protection Agency, 2000)

${ }^{\mathrm{b}}$ Primary Drinking Water Standard (U.S. Environmental Protection Agency, 2000)

${ }^{c}$ Drinking Water Equivalent Level (U.S. Environmental Protection Agency, 2000) 
Table 6. Results of analyses for organic compounds in water samples collected from borehole FL-800 during borehole development on April 8 and 9, 1996, and from intervals F, E, D, and C sampled during aquifer testing on April 24 and 25, 1996 at the study site in the vicinity of Waupun, Fond du Lac County, Wis.

[all values reported in micrograms per liter; MCL, maximum contaminant level; - -, no established MCL; <, less than detection limit; (J), estimated value; (B), detected in laboratory blank; -, not analyzed; altitudes of packed intervals defined in table 4; intervals depicted in figure 7; analyses were conducted by U.S. Environmental Protection Agency Central Regional Laboratory in Chicago, Illinois]

\begin{tabular}{|c|c|c|c|c|c|c|c|c|}
\hline Compound & $\mathrm{MCL}^{\mathrm{a}}$ & $\begin{array}{c}\text { FL-800 } \\
\text { development }\end{array}$ & $\begin{array}{c}\text { FL-800 } \\
\text { development, } \\
\text { duplicate }\end{array}$ & $\begin{array}{c}\text { FL-800 } \\
\text { Interval F }\end{array}$ & $\begin{array}{c}\text { FL-800' } \\
\text { Interval E }\end{array}$ & $\begin{array}{c}\text { FL-800 } \\
\text { Interval E } \\
\text { (duplicate) }\end{array}$ & $\begin{array}{c}\text { FL-800 } \\
\text { Interval D }\end{array}$ & $\begin{array}{c}\text { FL-800 } \\
\text { Interval C }\end{array}$ \\
\hline Chloromethane & - & $<1$ & $<1$ & $<3$ & $<3(\mathrm{~J})$ & $<3$ & $<3$ & $<3$ \\
\hline Vinyl chloride & 2 & $<1$ & $<1$ & $<3$ & $<3(\mathrm{~J})$ & $<3$ & $<3$ & $<3$ \\
\hline Bromomethane & - - & $<1$ & $<1$ & $<3(\mathrm{~J})$ & $<3(\mathrm{~J})$ & $<3(\mathrm{~J})$ & $<3(\mathrm{~J})$ & $<3(\mathrm{~J})$ \\
\hline Chloroethane & - - & $<1$ & $<1$ & $<3(\mathrm{~J})$ & $<3(\mathrm{~J})$ & $<3$ & $<3$ & $<3$ \\
\hline 1,1-Dichloroethene & - - & $<1$ & $<1$ & $<2$ & $<2(\mathrm{~J})$ & $<2$ & $<2$ & $<2$ \\
\hline Acetone & - - & $<3(J)$ & $<3(J)$ & $<10$ & $6(\mathrm{~J})$ & $<10$ & $<10$ & $<10$ \\
\hline Carbon disulfide & - & $<1$ & $<1$ & $<2$ & $<2(J)$ & $<2$ & $<2$ & $<2$ \\
\hline Methylene chloride & - - & $1(\mathrm{~B})$ & $2(\mathrm{~B})$ & $<2$ & $<2(\mathrm{~J})$ & $<2$ & $<2$ & $<2$ \\
\hline trans-1,2-Dichloroethene & - - & $<1$ & $<1$ & $<2$ & $<2(\mathrm{~J})$ & $<2$ & $<2$ & $<2$ \\
\hline 1,1-Dichloroethane & -- & $<1$ & $<1$ & $<2$ & $<2(\mathrm{~J})$ & $<2$ & $<2$ & $<2$ \\
\hline 2,2-Dichloropropane & 5 & $<1$ & $<1$ & $<2$ & $<2(\mathrm{~J})$ & $<2$ & $<2$ & $<2$ \\
\hline cis-1,2-Dichloroethene & - & $<1$ & $<1$ & $<2$ & $<2(\mathrm{~J})$ & $<2$ & $<2$ & $<2$ \\
\hline 2-Butanone & - - & $<3$ & $<3$ & $<10$ & $<10(\mathrm{~J})$ & $<10$ & $<10$ & $<10$ \\
\hline Bromochloromethane & - - & $<1$ & $<1$ & $<2$ & $<2(\mathrm{~J})$ & $<2$ & $<2$ & $<2$ \\
\hline Chloroform & - - & $<1$ & $<1$ & $<2$ & $<2(\mathrm{~J})$ & $<2$ & $<2$ & $<2$ \\
\hline 1,1,1-Trichloroethane & 200 & $<1$ & $<1$ & $<2$ & $<2(\mathrm{~J})$ & $<2$ & $<2$ & $<2$ \\
\hline Carbon tetrachloride & 5 & $<1$ & $<1$ & $<2$ & $<2(J)$ & $<2$ & $<2$ & $<2$ \\
\hline 1,1-Dichloropropene & - - & $<1$ & $<1$ & $<2$ & $<2(J)$ & $<2$ & $<2$ & $<2$ \\
\hline Benzene & 5 & $<1$ & $<1$ & $<2$ & $<2(J)$ & $<2$ & $<2$ & $<2$ \\
\hline 1,2-Dichloroethene & - - & $<1$ & $<1$ & $<2$ & $<2(J)$ & $<2$ & $<2$ & $<2$ \\
\hline Trichloroethene & - - & $0.5(\mathrm{~J})$ & 1 & $<2$ & $<2(J)$ & $<2$ & $<2(\mathrm{~J})$ & $<2$ \\
\hline 1,2-Dichloropropane & 5 & $<1$ & $<1$ & $<2$ & $<2(J)$ & $<2$ & $<2$ & $<2$ \\
\hline Dibromomethane & - - & $<1$ & $<1$ & $<2$ & $<2(J)$ & $<2$ & $<2$ & $<2$ \\
\hline Bromodichloromethane & - - & $<1$ & $<1$ & $<2$ & $<2(J)$ & $<2$ & $<2$ & $<2$ \\
\hline cis-1,3-Dichloropropene & -- & $<1$ & $<1$ & $<2$ & $<2(J)$ & $<2$ & $<2$ & $<2$ \\
\hline Toluene & 1,000 & $<1$ & $<1$ & $1(\mathrm{~J})$ & $<2(J)$ & $0.7(J)$ & $<2$ & $0.5(\mathrm{~J})$ \\
\hline 4-Methyl-2-Pentanone & - - & $<2$ & $<2$ & $<5$ & $<5(J)$ & $<5$ & $<5$ & $<5$ \\
\hline trans-1,3-Dichloropropene & - & $<1$ & $<1$ & $<2$ & $<2(J)$ & $<2$ & $<2$ & $<2$ \\
\hline Tetrachloroethene & - - & $0.5(\mathrm{~J})$ & $<0.5(\mathrm{~J})$ & $<2$ & $<2(J)$ & $<2$ & $<2$ & $<2$ \\
\hline 1,1,2-Trichloroethane & 5 & $<1$ & $1(\mathrm{~J})$ & $<2$ & $<2(\mathrm{~J})$ & $<2$ & $<2$ & $<2$ \\
\hline 1,3-Dichloropropane & - - & $<1$ & $<1$ & $<2$ & $<2(\mathrm{~J})$ & $<2$ & $<2$ & $<2$ \\
\hline 2-Hexanone & - & $<2$ & $<2$ & $<5$ & $<5(\mathrm{~J})$ & $<5$ & $<5$ & $<5$ \\
\hline Dibromochloromethane & - - & $<1$ & $<1$ & $<2$ & $<2(\mathrm{~J})$ & $<2$ & $<2$ & $<2$ \\
\hline 1,2-Dibromoethane & - - & $<1$ & $<1$ & $<2$ & $<2(\mathrm{~J})$ & $<2$ & $<2$ & $<2$ \\
\hline
\end{tabular}


Table 6. Results of analyses for organic compounds in water samples collected from borehole FL-800 during borehole development on April 8 and 9, 1996, and from intervals F, E, D, and C sampled during aquifer testing on April 24 and 25, 1996 at the study site in the vicinity of Waupun, Fond du Lac County, Wis.-Continued.

[all values reported in micrograms per liter; MCL, maximum contaminant level; --, no established MCL; <, less than detection limit; (J), estimated value; (B), detected in laboratory blank; - , not analyzed; altitudes of packed intervals defined in table 4; intervals depicted in figure 7; analyses were conducted by U.S. Environmental Protection Agency Central Regional Laboratory in Chicago, Illinois]

\begin{tabular}{|c|c|c|c|c|c|c|c|c|}
\hline Compound & MCL $^{\mathrm{a}}$ & $\begin{array}{c}\text { FL-800 } \\
\text { development }\end{array}$ & $\begin{array}{c}\text { FL-800 } \\
\text { development, } \\
\text { duplicate }\end{array}$ & $\begin{array}{c}\text { FL-800 } \\
\text { Interval F }\end{array}$ & $\begin{array}{c}\text { FL-800 } \\
\text { Interval E }\end{array}$ & $\begin{array}{c}\text { FL-800 } \\
\text { Interval E } \\
\text { (duplicate) }\end{array}$ & $\begin{array}{c}\text { FL-800 } \\
\text { Interval D }\end{array}$ & $\begin{array}{c}\text { FL-800 } \\
\text { Interval C }\end{array}$ \\
\hline Chlorobenzene & 100 & $<1$ & $<1$ & $<2$ & $<2(\mathrm{~J})$ & $<2$ & $<2$ & $<2$ \\
\hline 1,1,2,2-Tetrachloroethane & - - & $<1$ & $<1$ & $<2$ & $<2(\mathrm{~J})$ & $<2$ & $<2$ & $<2$ \\
\hline Ethylbenzene & 700 & $<1$ & $<1$ & $<2$ & $<2(\mathrm{~J})$ & $<2$ & $<2$ & $<2$ \\
\hline m \&/or p-Xylene & - - & $<1$ & $<1$ & $<2$ & $<2(\mathrm{~J})$ & $<2$ & $<2$ & $<2$ \\
\hline o-Xylene & -- & $<1$ & $<1$ & $<2$ & $<2(\mathrm{~J})$ & $<2$ & $<2$ & $<2$ \\
\hline Styrene & 100 & $<1$ & $<1$ & $<2$ & $<2(\mathrm{~J})$ & $<2$ & $<2$ & $<2$ \\
\hline Bromoform & - - & $<1$ & $<1$ & $<2$ & $<2(\mathrm{~J})$ & $<2$ & $<2$ & $<2$ \\
\hline Isopropylbenzene & - & $<1$ & $<1$ & $<2$ & $<2(\mathrm{~J})$ & $<2$ & $<2$ & $<2$ \\
\hline Bromobenzene & - - & $<1$ & $<1$ & $<2$ & $<2(\mathrm{~J})$ & $<2$ & $<2$ & $<2$ \\
\hline 1,2,3-Trichloropropane & - - & $<1$ & $<1$ & $<2$ & $<2(\mathrm{~J})$ & $<2$ & $<2$ & $<2$ \\
\hline 1,1,2,2-Tetrachloroethane & -- & $<1$ & $<1$ & $<2$ & $<2(J)$ & $<2$ & $<2$ & $<2$ \\
\hline n-Propylbenzene & -- & $<1$ & $<1$ & $<2$ & $<2(\mathrm{~J})$ & $<2$ & $<2$ & $<2$ \\
\hline 2-Chlorotoluene & -- & $<1$ & $<1$ & $<2$ & $<2(\mathrm{~J})$ & $<2$ & $<2$ & $<2$ \\
\hline 4-Chlorotoluene & - & $<1$ & $<1$ & $<2$ & $<2(\mathrm{~J})$ & $<2$ & $<2$ & $<2$ \\
\hline 1,3,5-Trimethylbenzene & -- & $<1$ & $<1$ & $<2$ & $<2(J)$ & $<2$ & $<2$ & $<2$ \\
\hline tert-Butylbenzene & - & $<1$ & $<1$ & $<2$ & $<2(J)$ & $<2$ & $<2$ & $<2$ \\
\hline 1,2,4-Trimethylbenzene & - & $<1$ & $<1$ & $<2$ & $<2(\mathrm{~J})$ & $<2$ & $<2$ & $<2$ \\
\hline sec-Butylbenzene & - - & $<1$ & $<1$ & $<2$ & $<2(J)$ & $<2$ & $<2$ & $<2$ \\
\hline 1,3-Dichlorobenzene & -- & $<1$ & $<1$ & $<2$ & $<2(J)$ & $<2$ & $<2$ & $<2$ \\
\hline 1,4-Dichlorobenzene & -- & $<1$ & $<1$ & $<2$ & $<2(J)$ & $<2$ & $<2$ & $<2$ \\
\hline p-Isopropyltoluene & -- & $<1$ & $<1$ & $<2$ & $<2(\mathrm{~J})$ & $<2$ & $<2$ & $<2$ \\
\hline 1,2-Dichlorobenzene & -- & $<1$ & $<1$ & $<2$ & $<2(\mathrm{~J})$ & $<2$ & $<2$ & $<2$ \\
\hline n-Butylbenzene & -- & $<1$ & $<1$ & $<2$ & $<2(\mathrm{~J})$ & $<2$ & $<2$ & $<2$ \\
\hline $\begin{array}{l}\text { 1,2-Dibromo-3- } \\
\text { chloropropane }\end{array}$ & -- & $<1$ & $<1$ & $<2$ & $<2(\mathrm{~J})$ & $<2$ & $<2$ & $<2$ \\
\hline 1,2,4-Trichlorobenzene & -- & $<1$ & $<1$ & $<2$ & $<2(\mathrm{~J})$ & $<2$ & $<2$ & $<2$ \\
\hline Naphthalene & -- & $<1$ & $<1$ & $<2$ & $<2(\mathrm{~J})$ & $<2$ & $<2$ & $<2$ \\
\hline Hexachlorobutadiene & -- & $<1$ & $<1$ & $<2$ & $<2(\mathrm{~J})$ & $<2$ & $<2$ & $<2$ \\
\hline 1,2,3-Trichlorobenzene & -- & $<1$ & $<1$ & $<2$ & $<2(\mathrm{~J})$ & $<2$ & $<2$ & $<2$ \\
\hline 3-Heptanone & -- & - & - & $4(J)$ & - & - & - & - \\
\hline Phenol & -- & $<5$ & $<5$ & - & - & - & - & - \\
\hline bis(2-Chloroethyl)ether & -- & $<5$ & $<5$ & - & - & - & - & - \\
\hline 2-Chlorophenol & -- & $<5$ & $<5$ & - & - & - & - & - \\
\hline 1,3-Dichlorobenzene & -- & $<5$ & $<5$ & - & - & - & - & - \\
\hline 1,4-Dichlorobenzene & - - & $<5$ & $<5$ & - & - & - & - & - \\
\hline
\end{tabular}


24 Lithostratigraphic and Hydrogeologic Characteristics of the Ordovician Sinnipee Group in the Vicinity of Waupun, Wis.

Table 6. Results of analyses for organic compounds in water samples collected from borehole FL-800 during borehole development on April 8 and 9, 1996, and from intervals F, E, D, and C sampled during aquifer testing on April 24 and 25, 1996 at the study site in the vicinity of Waupun, Fond du Lac County, Wis. - Continued.

[all values reported in micrograms per liter; MCL, maximum contaminant level; --, no established MCL; <, less than detection limit; (J), estimated value; (B), detected in laboratory blank; —, not analyzed; altitudes of packed intervals defined in table 4; intervals depicted in figure 7; analyses were conducted by U.S. Environmental Protection Agency Central Regional Laboratory in Chicago, Illinois]

\begin{tabular}{|c|c|c|c|c|c|c|c|c|}
\hline Compound & $\mathrm{MCL}^{\mathrm{a}}$ & $\begin{array}{c}\text { FL-800 } \\
\text { development }\end{array}$ & $\begin{array}{c}\text { FL-800 } \\
\text { development, } \\
\text { duplicate }\end{array}$ & $\begin{array}{l}\text { FL-800 } \\
\text { Interval F }\end{array}$ & $\begin{array}{c}\mathrm{FL}^{-800^{\mathrm{b}}} \\
\text { Interval E }\end{array}$ & $\begin{array}{c}\text { FL-800 } \\
\text { Interval E } \\
\text { (duplicate) }\end{array}$ & $\begin{array}{l}\text { FL-800 } \\
\text { Interval D }\end{array}$ & $\begin{array}{c}\text { FL-800 } \\
\text { Interval C }\end{array}$ \\
\hline Benzyl alcohol & - & $<5$ & $<5$ & - & - & - & - & - \\
\hline 1,2-Dichlorobenzene & - - & $<5$ & $<5$ & - & - & - & - & - \\
\hline 2-Methylphenol & - - & $<5$ & $<5$ & - & - & - & - & - \\
\hline $\begin{array}{l}\text { bis (2-Chloroisopropyl) } \\
\text { ether }\end{array}$ & - - & $<5$ & $<5$ & - & - & - & - & - \\
\hline 4-Methylphenol & - & $<5$ & $<5$ & - & - & - & - & - \\
\hline N-Nitroso-di-n-propylamine & - & $<5$ & $<5$ & - & - & - & - & - \\
\hline Hexachloroethane & - & $<5$ & $<5$ & - & - & - & - & - \\
\hline Nitrobenzene & - & $<5$ & $<5$ & - & - & - & - & - \\
\hline Isophorone & - - & $<5$ & $<5$ & - & - & - & - & - \\
\hline 2-Nitrophenol & - - & $<5$ & $<5$ & - & - & - & - & - \\
\hline 2,4-Dimethylphenol & -- & $<5$ & $<5$ & - & - & - & - & - \\
\hline Benzoic acid & - - & $<20$ & $<20$ & - & - & - & - & - \\
\hline bis(2-Chloroethoxy)methane & -- & $<5$ & $<5$ & - & - & - & - & - \\
\hline 2,4-Dichlorophenol & - & $<5$ & $<5$ & - & - & - & - & - \\
\hline 1,2,4-Trichlorobenzene & 70 & $<5$ & $<5$ & - & - & - & - & - \\
\hline Naphthalene & -- & $<5$ & $<5$ & - & - & - & - & - \\
\hline 4-Chloroaniline & -- & $<5$ & $<5$ & - & - & - & - & - \\
\hline Hexachlorobutadiene & -- & $<5$ & $<5$ & - & - & - & - & - \\
\hline 4-Chloro-3-methylphenol & -- & $<5$ & $<5$ & - & - & - & - & - \\
\hline 2-Methylnaphthalene & - & $<5$ & $<5$ & - & - & - & - & - \\
\hline Hexachlorocyclopentadiene & 50 & $<5$ & $<5$ & - & - & - & - & - \\
\hline 2,4,6-Trichlorophenol & -- & $<5$ & $<5$ & - & - & - & - & - \\
\hline 2,4,5-Trichlorophenol & -- & $<20$ & $<20$ & - & - & - & - & - \\
\hline 2-Chloronaphthalene & -- & $<5$ & $<5$ & - & - & - & - & - \\
\hline 2-Nitroaniline & -- & $<20$ & $<20$ & - & - & - & - & - \\
\hline Dimethylphthalate & -- & $<5$ & $<5$ & - & - & - & - & - \\
\hline Acenaphthylene & -- & $<5$ & $<5$ & - & - & - & - & - \\
\hline 2,6-Dinitrotoluene & -- & $<5$ & $<5$ & - & - & - & - & - \\
\hline 3-Nitroaniline & -- & $<20$ & $<20$ & - & - & - & - & - \\
\hline Acenaphthene & -- & $<5$ & $<5$ & - & - & - & - & - \\
\hline 2,4-Dinitrophenol & - - & $<20$ & $<20$ & - & - & - & - & - \\
\hline
\end{tabular}


Table 6. Results of analyses for organic compounds in water samples collected from borehole FL-800 during borehole development on April 8 and 9, 1996, and from intervals F, E, D, and C sampled during aquifer testing on April 24 and 25, 1996 at the study site in the vicinity of Waupun, Fond du Lac County, Wis. - Continued.

[all values reported in micrograms per liter; MCL, maximum contaminant level; --, no established MCL; <, less than detection limit; (J), estimated value; (B), detected in laboratory blank; - , not analyzed; altitudes of packed intervals defined in table 4; intervals depicted in figure 7; analyses were conducted by U.S. Environmental Protection Agency Central Regional Laboratory in Chicago, Illinois]

\begin{tabular}{|c|c|c|c|c|c|c|c|c|}
\hline Compound & $\mathrm{MCL}^{\mathrm{a}}$ & $\begin{array}{c}\text { FL-800 } \\
\text { development }\end{array}$ & $\begin{array}{c}\text { FL-800 } \\
\text { development, } \\
\text { duplicate }\end{array}$ & $\begin{array}{c}\text { FL-800 } \\
\text { Interval F }\end{array}$ & $\begin{array}{c}\text { FL-800' } \\
\text { Interval E }\end{array}$ & $\begin{array}{c}\text { FL-800 } \\
\text { Interval E } \\
\text { (duplicate) }\end{array}$ & $\begin{array}{c}\text { FL-800 } \\
\text { Interval D }\end{array}$ & $\begin{array}{c}\text { FL-800 } \\
\text { Interval C }\end{array}$ \\
\hline 4-Nitrophenol & -- & $<20$ & $<20$ & - & - & - & - & - \\
\hline Dibenzofuran & - & $<5$ & $<5$ & - & - & - & - & - \\
\hline 2,4-Dinitrotoluene & - - & $<5$ & $<5$ & - & - & - & - & - \\
\hline Diethylphthalate & -- & $<5(\mathrm{~J})$ & $<5$ & - & - & - & - & - \\
\hline 4-Chlorophenyl-phenylether & - - & $<5$ & $<5$ & - & - & - & - & - \\
\hline Fluorene & -- & $<5$ & $<5$ & - & - & - & - & - \\
\hline 4-Nitroaniline & -- & $<20$ & $<20$ & - & - & - & - & - \\
\hline 4,6-Dinitro-2-methylphenol & -- & $<20$ & $<20$ & - & - & - & - & - \\
\hline N-Nitrosodiphenylamine (1) & -- & $<5$ & $<5$ & - & - & - & - & - \\
\hline 4-Bromophenyl-phenylether & -- & $<5$ & $<5$ & - & - & - & - & - \\
\hline Hexachlorobenzene & 1 & $<5$ & $<5$ & - & - & - & - & - \\
\hline Pentachlorophenol & 1 & $<20$ & $<20$ & - & - & - & - & - \\
\hline Phenanthrene & - & $<5$ & $<5$ & - & - & - & - & - \\
\hline Anthracene & -- & $<5$ & $<5$ & - & - & - & - & - \\
\hline Di-n-butylphthalate & -- & $<1(\mathrm{~B}, \mathrm{~J})$ & $<1(\mathrm{~B}, \mathrm{~J})$ & - & - & - & - & - \\
\hline Fluoranthene & -- & $<5$ & $<5$ & - & - & - & - & - \\
\hline Pyrene & -- & $<5$ & $<5$ & - & - & - & - & - \\
\hline Butylbenzylphthalate & -- & $<5$ & $<5$ & - & - & - & - & - \\
\hline 3,3'-Dichlorobenzidine & -- & $<5$ & $<5$ & - & - & - & - & - \\
\hline Carbazole & -- & $<5$ & $<5$ & - & - & - & - & - \\
\hline Benzo(a)anthracene & -- & $<5$ & $<5$ & - & - & - & - & - \\
\hline Chrysene & -- & $<5$ & $<5$ & - & - & - & - & - \\
\hline bis(2-Ethylhexyl)phthalate & -- & $8(\mathrm{~B})$ & 10 (B) & - & - & - & - & - \\
\hline Di-n-octylphthalate & -- & $<5$ & $<5$ & - & - & - & - & - \\
\hline Benzo(b)fluoranthene & -- & $<5$ & $<5$ & - & - & - & - & - \\
\hline Benzo(k)fluoranthene & -- & $<5$ & $<5$ & - & - & - & - & - \\
\hline Benzo(a)pyrene & 0.2 & $<5$ & $<5$ & - & - & - & - & - \\
\hline Indeno(1,2,3-cd)pyrene & -- & $<5$ & $<5$ & - & - & - & - & - \\
\hline Dibenzo(a,h)anthracene & -- & $<5$ & $<5$ & - & - & - & - & - \\
\hline Benzo(g,h,i)perylene & -- & $<5$ & $<5$ & - & - & - & - & - \\
\hline
\end{tabular}

${ }^{\text {a }}$ Primary Drinking Water Standard (U.S. Environmental Protection Agency, 2000).

${ }^{\mathrm{b}}$ All samples, except those from interval E, met internal standard (IS) area quality control (QC) requirements. This sample was analyzed on April 29 and on April 30, 1996. Because all three IS area responses were biased low on both days of analysis, all TLC results for this sample are flagged with both "<" and "J" if less than detection limit, and flagged with "J" if detected. 


\section{EXPLANATION}

负 FL-800 packed interval C

$\square \quad$ FL-800 packed interval D

$\triangle$ FL-800 packed interval $\mathrm{E}$

$\bigcirc$ FL-800 packed interval F

Total dissolved solids,

in parts per million

(size of symbol indicates value)

[ 6992

$\longleftrightarrow] 1080$

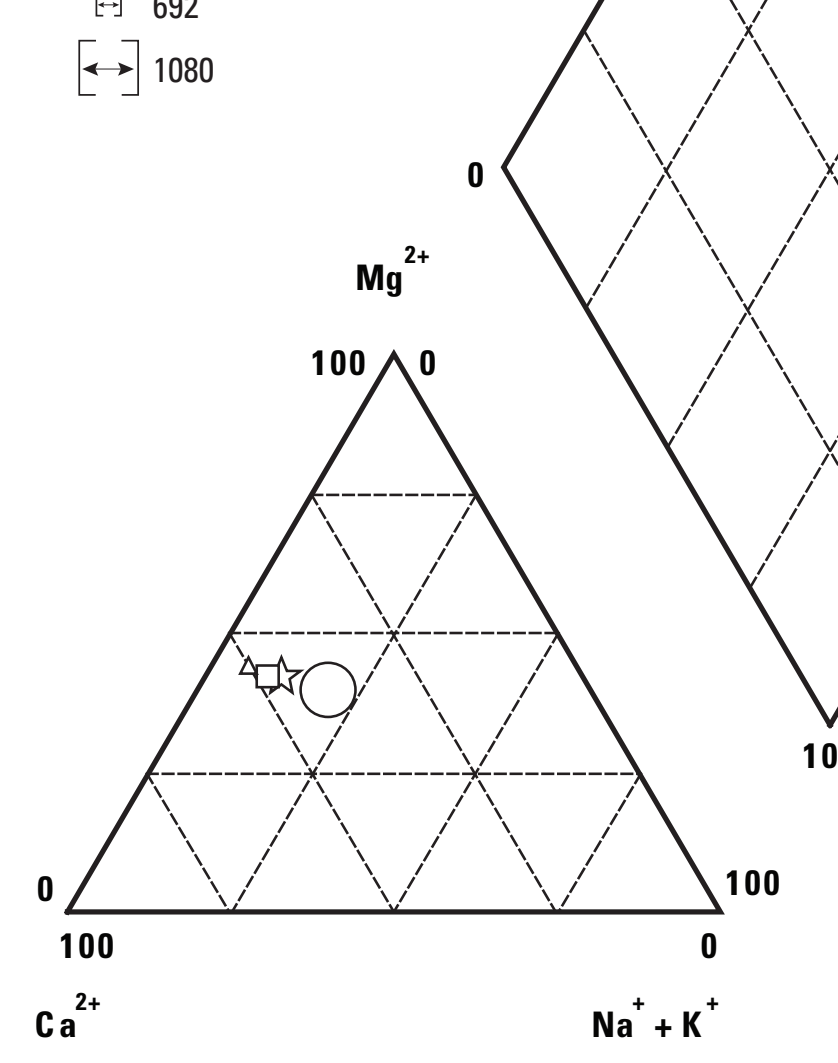

100

F




\section{Hardgrounds, Fractures, and Bedding-Plane Partings}

Both fractures and lithologic hardgrounds were described by the ISGS in the rock core from borehole FL-800. ISGS noted that hardgrounds were common in this core, some having stratigraphic significance. The hardgrounds have been classified into four categories (very well developed, well developed, weakly developed, and very weakly developed) based on the subjective judgment of the ISGS as to the degree of development. Four very well developed hardgrounds were identified, three of which were used as formation or member contacts (fig. 10). The hardground at about $797 \mathrm{ft}$ represents the top of the Platteville Formation, the hardground at about $754 \mathrm{ft}$ represents the top of the Pecatonica Member of the Platteville Formation, and the hardground at about $746 \mathrm{ft}$ represents the top of the Glenwood Formation. The fourth very well developed hardground, unrelated to a stratigraphic contact, is located at about $868 \mathrm{ft}$; however, this hardground, along with two well developed hardgrounds at about $871 \mathrm{ft}$ and $874 \mathrm{ft}$, appear related to two distinct bedding-plane partings in FL-800 that were tested in the packed intervals $\mathrm{K}$ and $\mathrm{D}$. Additional well developed hardgrounds could be related to bedding-plane partings between 893 and $895 \mathrm{ft}$.

Numerous fractures were noted to depths of about $177 \mathrm{ft}$, though fractures that appeared to be natural (not mechanically induced) were limited to depths above 80 $\mathrm{ft}$ - the section from $870 \mathrm{ft}$ and higher. Fractures were more numerous near the top of the core and were noted to be either vertical or nearly vertical, or at an angle of 30 to 40 degrees from vertical. The core was not oriented during drilling, so the azimuth of the fracture planes could not be estimated.

The evaluation of the single-hole directional groundpenetrating radar reflection survey in FL-800 identified 15 reflectors at the site. Radar reflectors may be associated with secondary permeability features, including fractures. Two reflectors have strikes of 40 to 60 degrees from magnetic north, with a conjugate set of five reflectors at 130 to 150 degrees (table 7). Other strikes were interpreted from the data at 190 degrees (three reflectors) and 300 degrees (five reflectors). The dip of a reflector is measured by the tool as an angle with respect to the borehole (Lane and others, 1994). These data have been subtracted from 90 degrees (vertical borehole assumed) to obtain degrees of dip from horizontal (table 7). Reflector dips greater

Table 7. Single-hole ground-penetrating radar directional reflection survey indicating the strike directions, dips, and intersection with borehole of reflectors in borehole FL-800 at the study site in the vicinity of Waupun, Fond du Lac County, Wis.

[datum is top of casing, estimated to be 950 feet above the National Geodetic Vertical Datum of 1929 (NGVD 29)]

\begin{tabular}{ccc}
\hline $\begin{array}{c}\text { Strike of reflector } \\
\text { (degrees from } \\
\text { magnetic north) }\end{array}$ & $\begin{array}{c}\text { Dip of reflector } \\
\text { (degrees from } \\
\text { horizontal) }\end{array}$ & $\begin{array}{c}\text { Projected altitude of intersection } \\
\text { with borehole } \\
\text { (feet above NGVD 29) }\end{array}$ \\
\hline 40 & 88.9 & $3,693.24$ \\
130 & 84.4 & $1,013.00$ \\
130 & 75.5 & 970.67 \\
130 & 28.3 & 932.94 \\
60 & 28.4 & 924.74 \\
190 & 60.8 & 922.11 \\
190 & 0.0 & 916.53 \\
190 & 0.0 & 906.69 \\
150 & Subhorizontal & 869.94 \\
150 & 1.6 & 852.55 \\
300 & 0.0 & 847.63 \\
300 & 14.5 & 815.48 \\
300 & 0.0 & 804.65 \\
300 & 0.0 & 797.43 \\
300 & 23.5 & 744.61 \\
\hline
\end{tabular}




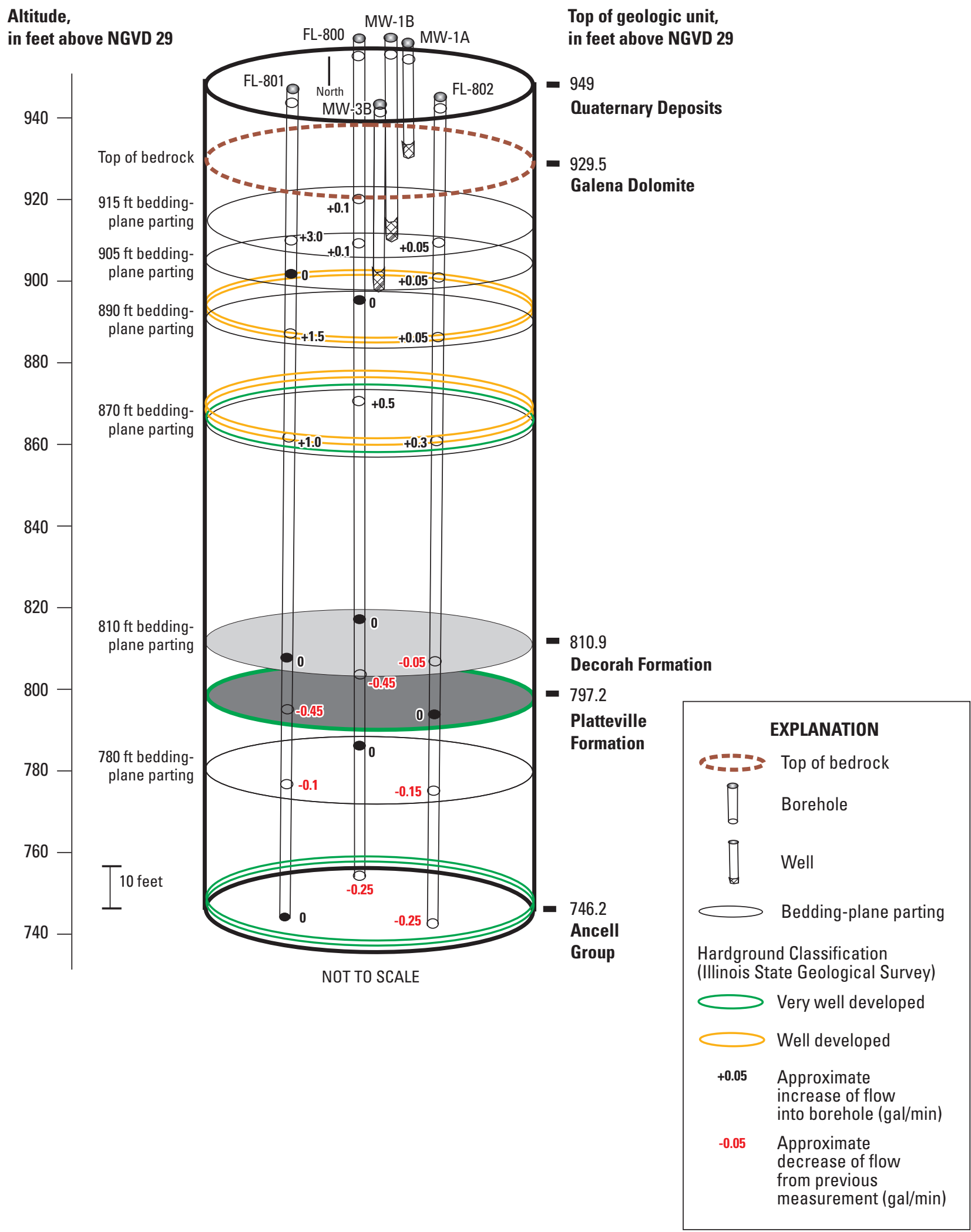

Figure 10. Selected hydrogeologic features at boreholes FL-800, FL-801, and FL-802 at the study site in the vicinity of Waupun, Fond du Lac County, Wis. (NGVD 29, National Geodetic Vertical Datum of 1929). 
than 45 degrees are found for reflectors with strikes of 45 , 130, and 190 degrees. Reflector dips less than 45 degrees are found for reflectors at all strikes except 45 degrees. Sub-horizontal dips are found for reflectors with strikes of 150, 190, and 300 degrees. The interpretation of these data includes a "depth of intersection" for each reflector (table 7); this is the depth at which the reflector would intersect the borehole if it were large enough and areally extensive enough to do so. These depths are "tie-points" that allow one to reconstruct the geometry and location of the reflectors with respect to the borehole (Lane and others, 1994; Singha and others, 2000).

Comparison of the projected depth of intersection of the reflectors with borehole FL-800 to the acoustic televiewer and caliper logs indicate that some reflectors do appear to intersect the borehole. Specifically, horizontal or sub-horizontal reflectors projected to intersect the borehole at about $917 \mathrm{ft}, 907 \mathrm{ft}, 870 \mathrm{ft}, 805 \mathrm{ft}$, and $797 \mathrm{ft}$ are seen to correlate with indications of bedding-plane partings on the acoustic televiewer log and, for altitudes of 917 and 870 $\mathrm{ft}$, a caliper diameter greater than the nominal 6 in. (fig. 5). Four of these five indications of horizontal partings are within packed intervals subjected to slug or aquifer tests - $917 \mathrm{ft}$ is the bottom of interval F, $907 \mathrm{ft}$ is at the top of interval E, $870 \mathrm{ft}$ is within intervals $\mathrm{K}$ and D, and $797 \mathrm{ft}$ is within interval G. In addition, the reflector at $797 \mathrm{ft}$ correlates with a very well developed hardground described in the rock core. Though some of the GPR reflectors do correlate with fractures and partings noted on geophysical logs and rock core, many additional fractures with a range of dips and partings identified by the televiewer log and (or) core description were not measured by the borehole radar survey. Two possible explanations for this absence are (1) the fractures are discontinuous over their length or do not provide a high enough contrast in electromagnetic properties to generate a good reflection, or (2) the steep dip of the fractures combined with low-frequency ringing in the data might have obscured the reflections (Kay and others, 2004).

The information provided by the core description and ground-penetrating radar is consistent with interpretation of borehole permeability on the basis of heat-pulse flowmeter logs. Downward flow, ranging from 0.2 to $0.8 \mathrm{gal} / \mathrm{min}$, occurred under ambient conditions in all three boreholes. The flowmeter profiles (figs. 5, 6, and 7) indicate that water entering and exiting the boreholes at seven bedding-plane partings accounts for most of the total borehole transmissivity. Although the same bedding planes generally are active in all three boreholes, the amount of water contributed from each parting differs between boreholes. In addition, the water level at about $915 \mathrm{ft}$ in all three holes coincides with a prominent bedding plane as evidenced by the caliper log. This bedding plane could not be imaged with the televiewer because the televiewer only works in a fluid-filled borehole.

The flowmeter profiles in all three boreholes show that more than 90 percent of the total borehole transmissivity is provided by bedding-plane partings found at $870 \mathrm{ft}$ and higher (figs. 5, 6, and 7). This is the same part of the rock core that has the greatest number of natural fractures, though these fractures have been described as (near) vertical or with 30- to 40-degree dips. The section $870 \mathrm{ft}$ and higher is stratigraphically within the Wise Lake and Dunleith Members of the Galena Dolomite (table 2). On the basis of the interpretation of flowmeter data, the bedding plane parting at about $905 \mathrm{ft}$ contributes 10 to 20 percent of the total borehole transmissivity in FL-800 and FL-802, but contributes none in FL-801. The beddingplane parting at about $890 \mathrm{ft}$ contributes 20 to 25 percent of the total borehole transmissivity in FL-801 and FL-802, but contributes none in FL-800. This is an indication that although bedding-plane partings are observed to be laterally extensive, they are not necessarily always hydraulically well-connected.

Ambient and steady injection conditions were used as two different head conditions under which to measure flow in the boreholes; the data are plotted as discrete flowmeter measurements (data) and as "step profiles" (interpretation) for each borehole (figs. 5, 6, and 7) (Paillet, 1995; Paillet, 1998; Paillet and others, 1987; Paillet and Reese, 2000). Comparison of step profiles shows that the pair of bedding-plane partings near $870 \mathrm{ft}$ is much more permeable than any of the other bedding-plane partings intersecting the borehole. This statement is qualified by the recognition that the bedding plane parting near $915 \mathrm{ft}$ is not fully saturated, so flow data may not accurately reflect the relative permeability of that parting. To compare the relative permeability of the partings between boreholes, relative flows must be normalized. This is done by measuring the increase in measured head produced by the injection for each borehole. The boreholes, however, were so productive that no head change could be measured (a common problem of cascading water during injection and almost instantaneous recovery). The head difference between the top and bottom of each borehole is probably about the same under ambient conditions (Fred Paillet, U.S. Geological Survey, written commun., 1999). Nonetheless, the 870 $\mathrm{ft}$ zone of FL-802 may be somewhat less permeable than the same zone in the other wells because the measured ambient flow is less. 


\section{Hydraulic Properties}

The results of the aquifer tests are consistent with the interpretation of lithologic data that ground-water flow within the Sinnipee Group at the study site is primarily through horizontal bedding-plane partings. However, evaluation of the responses to imposed aquifer stresses suggests a complex vertical interconnection between bedding-plane partings.

\section{Vertical-Flow Characteristics}

During the development of the boreholes, MW-3B demonstrated significantly more response to pumping of FL-800 and FL-801 than did MW-1B (which essentially showed no response), even though both wells are screened over the same vertical interval and MW-1B is very close to FL-800 (fig. 2). Well MW-1A did show a response to the pumping, although it was small. This anisotropy may be a further reflection of the influence of the sub-vertical fractures observed in the televiewer logs and identified as reflectors by ground-penetrating radar.

Static water levels were measured in selected intervals of the three boreholes (fig. 3 and table 8), and vertical hydraulic gradients were estimated by comparing levels in adjacent intervals (table 9). Gradients were found to be almost uniformly downward (identified with negative value), ranging from -0.040 to $-1.251 \mathrm{ft} / \mathrm{ft}$. Upward gradients were found in adjacent intervals $\mathrm{G} / \mathrm{B}, \mathrm{H} / \mathrm{C}, \mathrm{K} / \mathrm{H}$, and I/D and range from 0.006 to $0.797 \mathrm{ft} / \mathrm{ft}$. The lowest static water level was measured in interval G of FL-800 at 780.1 to $800.0 \mathrm{ft}$; the water level was more than $7 \mathrm{ft}$ lower than the next lowest measured level. This might indicate that the water level in this interval had not reached equilibrium at the time it was measured; however, the reported water level was measured 17 hours after the packers were set and had remained within a few hundredths of a foot for at least 1.5 hours. The second lowest static water level in FL800 was measured in interval A, a zone that includes the base of the Sinnipee Group and the top of the Glenwood Formation. Neither interval G nor A contain observable bedding-plane partings, and both exhibited extremely long recovery times during their slug tests, indicating low matrix permeability.

Although some secondary permeability development is present in the Sinnipee Group, the generally massive nature of the units restricts the easy passage of water downward, resulting in the observed downward hydraulic gradient. The overall nature of downward gradients, however, indicates that ground water recharging the Sin- nipee Group will ultimately move to underlying bedrock units. Comparison of the two Sinnipee Group intervals that were chosen for the multiple-well constant-discharge tests (intervals $\mathrm{K}$ and $\mathrm{J}$ ) shows a consistent downward gradient in the three boreholes of -0.057 to $-0.062 \mathrm{ft} / \mathrm{ft}$ (table 9).

During the multiple-well constant-discharge testing of interval $\mathrm{K}$ (isolating the bedding plane parting at 870 feet and three hardgrounds above [fig. 10]) the stress appears to have been transmitted above the packed interval in all three boreholes during all three tests (appendix B). Generally, the water levels monitored above the isolated pumped interval exhibited a hydraulic response similar to the observed response in the pumped interval, but at approximately one-half the magnitude (appendix B). This is true for all three boreholes except for pumping from FL-801; in this case the response of the water levels monitored above the isolated pumped interval was observed to be substantially less than one-half the magnitude of the response of the pumped interval. No other vertical transmission was noted during these tests, either below the packed interval for the $\mathrm{K}$ interval tests, or above or below the packed interval for the $\mathrm{J}$ interval tests.

Also observed in borehole FL-801 during all of the multiple-well constant-discharge tests was a slight oscillation in the water levels measured below the packed intervals. The magnitude of the oscillation was approximately $0.02 \mathrm{ft}$ and was observed on a cycle of approximately 80 minutes. This would indicate the possibility of a hydraulic connection to an outside aquifer stress, such as a pumping well, present in FL-801 but not in the other boreholes. A possible explanation is that FL-800 and FL-802 are hydraulically well-connected to the bedrock at the bottom of the borehole, as demonstrated by flowmeter results showing 0.25 gpm of flow into the Ancell Group, whereas FL-801 does not show that same flow at the bottom of the borehole (figs. 5, 6, and 7). Without that same hydraulic connection, FL-801 might be more likely to show very subtle effects of local stresses in the Sinnipee Group aquifer. 
Table 8. Measured static water levels in selected intervals in boreholes FL-800, FL-801, and FL-802 at the study site in the vicinity of Waupun, Fond du Lac County, Wis.

[intervals are depicted in figure 3; NGVD 29, National Geodetic Vertical Datum of 1929]

\begin{tabular}{|c|c|c|c|c|}
\hline Borehole & $\begin{array}{l}\text { Packed } \\
\text { interval }\end{array}$ & $\begin{array}{c}\text { Packed Interval } \\
\text { (feet above NGVD 29) }\end{array}$ & Stratigraphic unit & $\begin{array}{l}\text { Static water level } \\
\text { (interval, in feet above } \\
\text { NGVD 29) }\end{array}$ \\
\hline FL- $800^{\text {a }}$ & $\mathrm{F}^{\mathrm{b}}$ & $917.0-922.5$ & $\begin{array}{l}\text { Galena Dolomite-Wise Lake and Dunleith Dolomite } \\
\text { Members }\end{array}$ & 922.45 \\
\hline FL-800 & $\mathrm{E}$ & $905.0-907.0$ & $\begin{array}{l}\text { Galena Dolomite-Wise Lake and Dunleith Dolomite } \\
\text { Members }\end{array}$ & 915.47 \\
\hline FL-800 & I & $882.1-892.0$ & $\begin{array}{l}\text { Galena Dolomite-Wise Lake and Dunleith Dolomite } \\
\text { Members }\end{array}$ & 914.71 \\
\hline FL-800 & $\mathrm{D}$ & $870.0-872.0$ & $\begin{array}{l}\text { Galena Dolomite-Wise Lake and Dunleith Dolomite } \\
\text { Members }\end{array}$ & 914.80 \\
\hline FL-800 & $\mathrm{K}$ & $865.9-877.4$ & $\begin{array}{l}\text { Galena Dolomite-Wise Lake and Dunleith Dolomite } \\
\text { Members }\end{array}$ & 911.34 \\
\hline FL-800 & $\mathrm{H}$ & $824.1-844.0$ & $\begin{array}{l}\text { Galena Dolomite-Wise Lake and Dunleith Dolomite } \\
\text { Members }\end{array}$ & 912.15 \\
\hline FL-800 & $\mathrm{C}$ & $808.0-810.0$ & Decorah Formation-Spechts Ferry Shale & 912.70 \\
\hline FL-800 & $\mathrm{J}$ & $805.9-817.4$ & $\begin{array}{l}\text { Galena Dolomite_-Wise Lake and Dunleith Dolomite } \\
\text { Members, and Decorah Formation—Spechts Ferry } \\
\text { Shale }\end{array}$ & 907.63 \\
\hline FL-800 & G & $780.1-800.0$ & Platteville Formation—Quimby's Mill Member & 889.00 \\
\hline FL-800 & $\mathrm{B}$ & $765.0-767.0$ & Platteville Formation-McGregor Member & 908.16 \\
\hline FL-800 & $A^{c}$ & $743.0-755.0$ & $\begin{array}{l}\text { Platteville Formation-Pecatonica Member and Ancell } \\
\text { Group_-Glenwood Formation }\end{array}$ & 896.22 \\
\hline FL- $801^{\mathrm{d}}$ & $\mathrm{K}$ & $863.8-875.5$ & $\begin{array}{l}\text { Galena Dolomite-Wise Lake and Dunleith Dolomite } \\
\text { Members }\end{array}$ & 911.32 \\
\hline FL-801 & $\mathrm{J}$ & $803.8-815.5$ & $\begin{array}{l}\text { Galena Dolomite-Wise Lake and Dunleith Dolomite } \\
\text { Members, and Decorah Formation-Spechts Ferry } \\
\text { Shale }\end{array}$ & 907.84 \\
\hline FL-802 & K & $863.1-874.6$ & $\begin{array}{l}\text { Galena Dolomite-Wise Lake and Dunleith Dolomite } \\
\text { Members }\end{array}$ & 911.32 \\
\hline FL-802 & $\mathrm{J}$ & $803.1-814.6$ & $\begin{array}{l}\text { Galena Dolomite_-Wise Lake and Dunleith Dolomite } \\
\text { Members, and Decorah Formation-Spechts Ferry } \\
\text { Shale }\end{array}$ & 907.90 \\
\hline
\end{tabular}

${ }^{\text {a }}$ Ground level of FL-800 estimated to be $949.00 \mathrm{ft}$ above NGVD 29 on the basis of topographic maps. Datum for packed intervals and static water levels are top of casing, estimated to be $950.00 \mathrm{ft}$ above NGVD 29.

${ }^{\mathrm{b}}$ Interval $\mathrm{F}$ defined by lower packer and top of static water surface.

${ }^{\mathrm{c}}$ Interval A defined by upper packer and bottom of borehole.

${ }^{\mathrm{d}}$ Packed intervals and static water levels reflect $+2.00 \mathrm{ft}$ difference in top of casing elevation of FL-801 compared to FL-800.

${ }^{\mathrm{e}}$ Packed intervals and static water levels reflect $+0.10 \mathrm{ft}$ difference in top of casing elevation of FL-802 compared to FL-800. 
Table 9. Vertical hydraulic gradients calculated between selected intervals in boreholes FL-800, FL-801, FL-802 at the study site in the vicinity of Waupun, Fond du Lac County, Wis.

[downward gradient is denoted by "-”; altitude of packed intervals defined in table 4; intervals are shown in figure 7]

\begin{tabular}{lcc}
\hline Borehole & $\begin{array}{c}\text { Packed intervals } \\
\text { compared }\end{array}$ & $\begin{array}{c}\text { Gradient } \\
\text { (feet per foot) }\end{array}$ \\
\hline FL-800 & F/E & -0.393 \\
& E/I & -0.040 \\
& I/D & 0.006 \\
& I/K & -0.219 \\
& D/H & -0.073 \\
& K/H & 0.020 \\
& K/J & -0.062 \\
& H/C & 0.024 \\
& H/J & -0.200 \\
& $\mathrm{C} / \mathrm{G}$ & -1.251 \\
& J/G & -0.863 \\
& G/B & 0.797 \\
& B/A & -0.724 \\
\hline FL-801 & K/J & -0.058 \\
\hline FL-802 & K/J & -0.057 \\
\hline
\end{tabular}

\section{Horizontal-Flow Characteristics}

Estimates of horizontal hydraulic conductivity (K) were made using the techniques of Hvorslev (1951) on data from displacement/recovery tests. As an example, data collected during the test of interval $\mathrm{C}$ of borehole FL-800 and calculations using the Hvorslev equation are presented in figure 11. Estimates of $\mathrm{K}$ for the isolated intervals in all three boreholes ranged over more than 2 orders of magnitude, from 0.3 to $61 \mathrm{ft} / \mathrm{d}$ (table 10). Intervals that included partings had estimated conductivities over the entire range from 0.3 to $61 \mathrm{ft} / \mathrm{d}$. Intervals that did not contain any partings identified by the caliper $\log$ (that is, intervals used to evaluate rock matrix) had estimated conductivities ranging from 0.4 to $5 \mathrm{ft} / \mathrm{d}$. Because of long recovery times, however, it was not possible to calculate $\mathrm{K}$ for intervals $\mathrm{A}, \mathrm{B}$, and $\mathrm{G}$ in FL-800; the long recovery times indicate that these intervals which tested matrix permeability have low values of $\mathrm{K}$.

The results of the displacement/recovery tests support the interpretation of greater permeability for bedding-plane partings identified by the caliper log than for the dolomite matrix. Interval K consistently had the highest estimated conductivity ( 26 to $55 \mathrm{ft} / \mathrm{d}$ ) in all the well bores (table 10). The test results are largely consistent with the interpretation of the heat-pulse flowmeter data that the partings present at about $870 \mathrm{ft}$ have the greatest relative permeability encountered in the borehole, combining for about 60 to 90 percent of the total permeability in any borehole (figs. 5, 6, and 7). Interval D in FL-800 was chosen to isolate the lower of the partings identified by the caliper and acoustic televiewer in interval K. Assuming the lower parting was successfully isolated by the test, the estimated conductivity is $61 \mathrm{ft} / \mathrm{d}$, about 22 percent greater than that for interval $\mathrm{K}$ $(55 \mathrm{ft} / \mathrm{d})$.

The results of the multiple-well constant-discharge aquifer tests are shown in figures 12 and 13. During the three separate tests of interval J, the maximum drawdown in a pumped borehole was observed to be greatest in FL800 (drawdown of about $33 \mathrm{ft}$ ), and least in FL-801 (drawdown of about $4.5 \mathrm{ft}$ ). In each of the three tests of interval $\mathrm{J}$, pumping from any of the three boreholes resulted in almost immediate drawdown in the others. Regardless of the magnitude of the drawdown in the pumped borehole, the drawdown in the other boreholes was about 1 foot at the end of the test (100 minutes). The pumped borehole recovered more quickly than the un-pumped boreholes during the tests when pumping was from FL-800 and FL-801. In contrast, the recovery of borehole FL-802 following pumping was quick at first, but then matched the recovery profiles of the un-pumped boreholes.

The maximum drawdown in a pumped borehole for interval K was observed in FL-801 (drawdown of about $1.3 \mathrm{ft}$ ), and least in FL-800 (drawdown of about $0.9 \mathrm{ft}$ ). As was seen in evaluation of interval $\mathrm{J}$, pumping from interval $\mathrm{K}$ in any of the three boreholes resulted in almost immediate drawdown in the un-pumped boreholes. Regardless of the magnitude of the drawdown in the pumped borehole, the drawdown in the un-pumped boreholes ranged from 0.6 to $0.7 \mathrm{ft}$ at the end of the test (100 minutes). The pumped borehole recovered quickly, but when it reached the water level observed in the un-pumped boreholes, it matched their recovery profiles. All the recovery profiles for the multiple-well constant-discharge aquifer test of interval $\mathrm{K}$ demonstrate that the recovering water levels rose even above the static level observed prior to the test, and also exhibited brief and slight indication of oscillation.

Maximum drawdown was much less for interval $\mathrm{K}$ in the pumped boreholes during multiple-well constantdischarge aquifer tests than was observed for interval J, indicating greater transmissivity in interval $\mathrm{K}$ (though there could be some contribution of water from above the 
isolated pumped interval $\mathrm{K}$ as suggested by observation of water levels [appendix B]).

The transmissivity and horizontal hydraulic conductivity of intervals $\mathrm{J}$ and $\mathrm{K}$ in each borehole were estimated using the Cooper and Jacobs (1946) straight-line method. As an example, data collected on drawdown in interval $\mathrm{J}$ of borehole FL-801 during pumping of borehole FL-800 and calculations using the Cooper and Jacobs equation are presented in figure 14. The transmissivity and conductivity of intervals $\mathrm{J}$ and $\mathrm{K}$ for all the multiple-well constantdischarge tests are summarized in table 11; these results show that estimated conductivities were consistent for each interval. In addition, conductivity for interval $\mathrm{K}$ (about 94 to $201 \mathrm{ft} / \mathrm{d}$ ) was consistently greater than for interval $\mathrm{J}$ (7 to $9 \mathrm{ft} / \mathrm{d}$ ). In applying the Cooper-Jacob straight-line method, Kruseman and de Ridder (1991) state that the quality of the data (error) is related to the value of $u$ $\left(\mathrm{u}=\mathrm{r}^{2} \mathrm{~S} / 4 \mathrm{~T} \mathrm{t}\right.$ ) calculated during the straight-line part of each aquifer test (where $r=$ distance between pumped and observed borehole, $\mathrm{S}=$ calculated storativity, $\mathrm{T}=\mathrm{calcu}-$ lated transmissivity, and $\mathrm{t}=$ elapsed time of the test). The error associated with the data is \pm 5 percent if the value of $\mathrm{u}$ is less than 0.1 in the straight-line portion of the data, and is \pm 1 percent if the value of $u$ is less than 0.01 . The estimates of conductivity for interval $\mathrm{J}$ in all boreholes have an associated error of \pm 5 percent; the estimates for interval $\mathrm{K}$ in all boreholes have an associated error of \pm 1 percent.

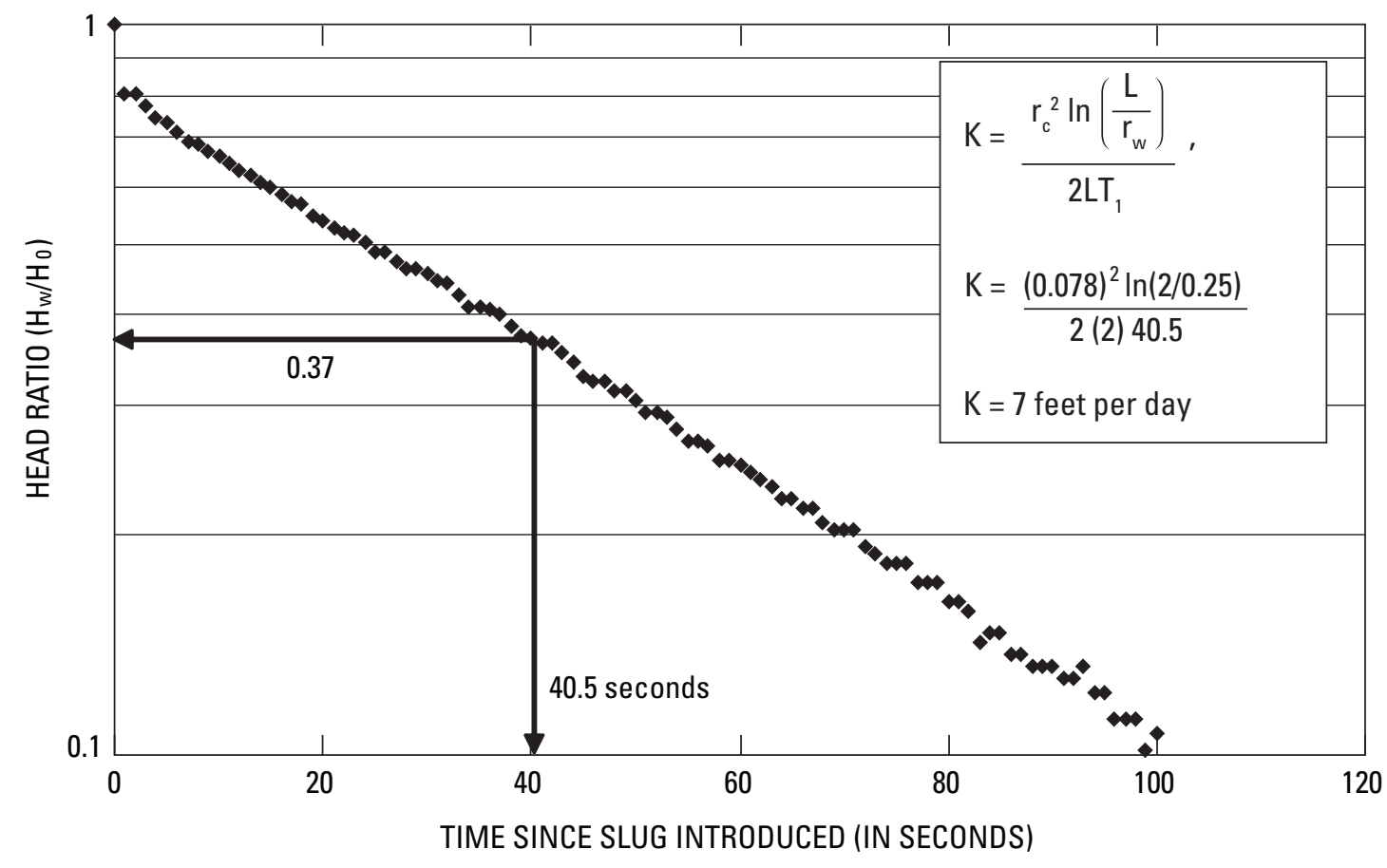

Figure 11. Slug test data collected from interval $\mathrm{C}$ of borehole FL-800 at the study site in the vicinity of Waupun, Fond du Lac County, Wis., and estimated horizontal hydraulic conductivity using Hvorslev equation (1951). (Intervals are shown in figure 3.) 
34 Lithostratigraphic and Hydrogeologic Characteristics of the Ordovician Sinnipee Group in the Vicinity of Waupun, Wis.

Table 10. Horizontal hydraulic conductivity of intervals in boreholes FL-800, FL-801, and FL-802 estimated from slug tests at the study site in the vicinity of Waupun, Fond du Lac County, Wis.

[- -, calculation was not possible because of unreliable data; - , calculation was not possible because of very long recovery time; altitude of packed intervals defined in table 4; intervals are depicted in figure 7; conductivity estimated using Hvorslev, 1951]

\begin{tabular}{|c|c|c|c|c|}
\hline Borehole & $\begin{array}{l}\text { Packed } \\
\text { interval }\end{array}$ & $\begin{array}{l}\text { Testing conductivity of } \\
\text { primarily matrix or parting }\end{array}$ & Length of tested interval & $\begin{array}{l}\text { Horizontal hydraulic conductivity } \\
\text { (feet per day) }\end{array}$ \\
\hline \multirow[t]{11}{*}{ FL-800 } & $\mathrm{F}^{\mathrm{a}}$ & Matrix & 5.5 & - \\
\hline & $\mathrm{E}^{\mathrm{b}}$ & Matrix & 2.0 & 5 \\
\hline & I & Parting & 10.0 & 8 \\
\hline & $\mathrm{D}$ & Parting & 2.0 & 61 \\
\hline & K & Parting & 11.5 & 50 \\
\hline & $\mathrm{H}$ & Matrix & 20.0 & 0.4 \\
\hline & $\mathrm{C}$ & Parting & 2.0 & 7 \\
\hline & $\mathrm{J}$ & Parting & 11.5 & 0.3 \\
\hline & G & Matrix & 20.0 & - \\
\hline & B & Matrix & 2.0 & - \\
\hline & A & Matrix & 12.0 & - \\
\hline \multirow[t]{2}{*}{ FL-801 } & $\mathrm{K}$ & Parting & 11.7 & 26 \\
\hline & $\mathrm{J}$ & Parting & 11.7 & 2 \\
\hline \multirow[t]{2}{*}{ FL-802 } & K & Parting & 11.5 & 55 \\
\hline & $\mathrm{J}$ & Parting & 11.5 & 0.7 \\
\hline
\end{tabular}

${ }^{a}$ Slug was 2 gallons of distilled water.

${ }^{\mathrm{b}}$ Slug was 1 gallon of distilled water. 
a)

Multiple-well constant-discharge aquifer test

2 gallons per minute pumped from $\mathrm{FL}-800$, Interval $\mathbf{J}$

Water levels observed in packed interval J of FL-800, FL-801, and FL-802

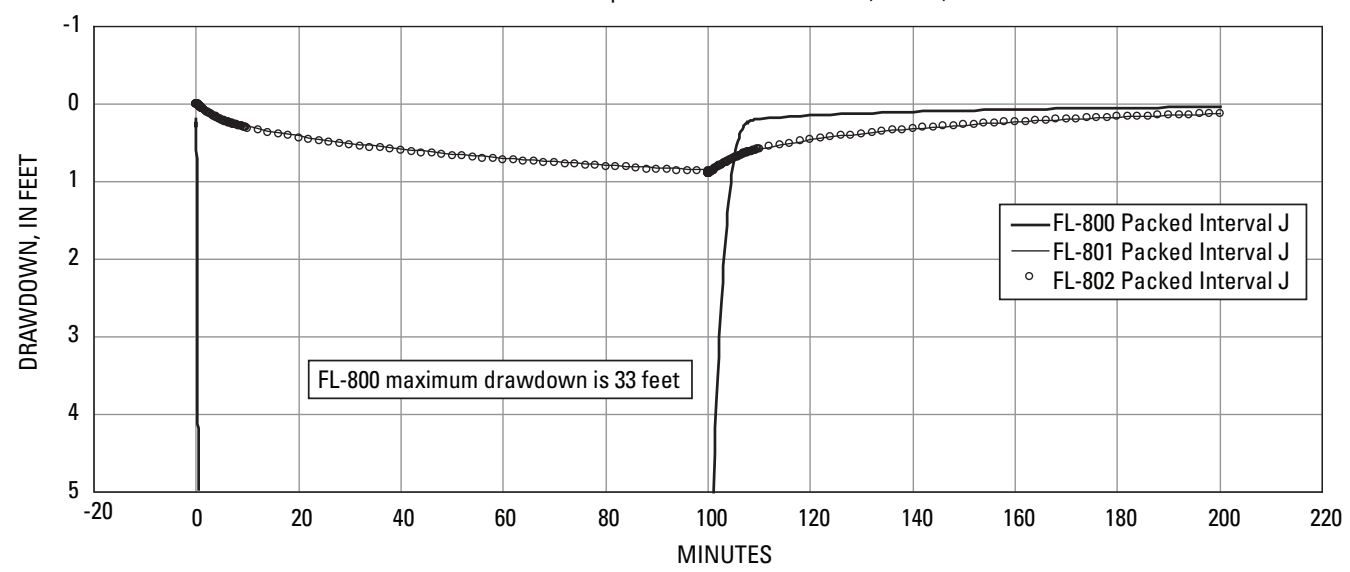

b)

Multiple-well constant-discharge aquifer test

2 gallons per minute pumped from FL-801, Interval $\mathbf{J}$

Water levels observed in packed interval $\mathrm{J}$ of FL-800, FL-801, and FL-802

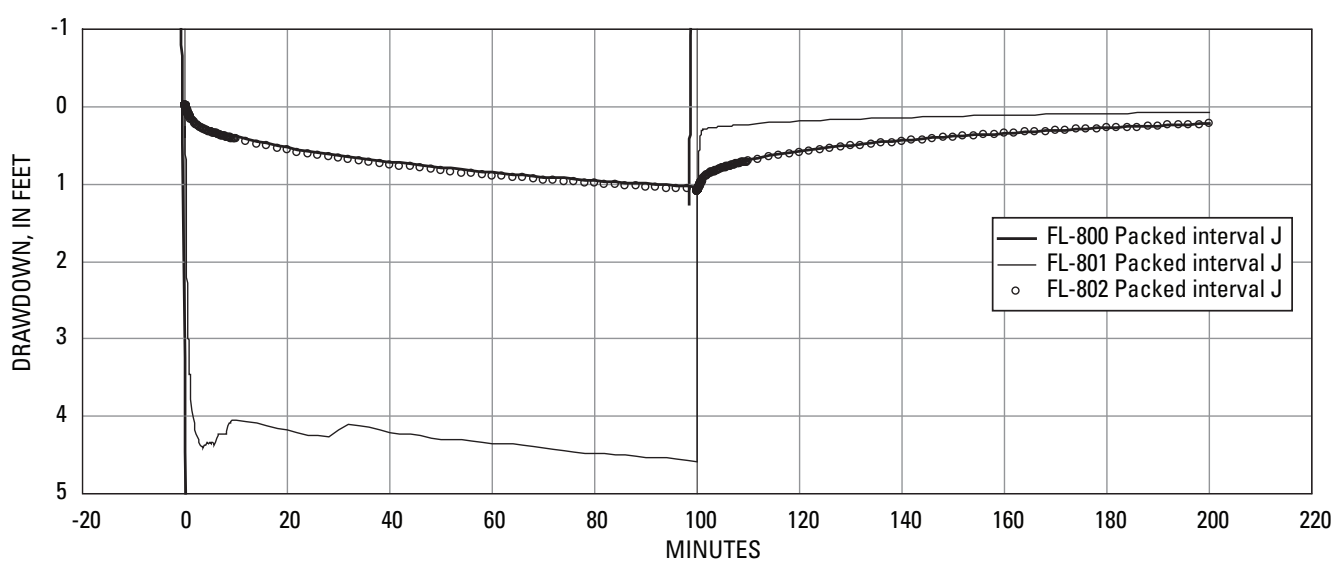

c)

Multiple-well constant-discharge aquifer test 2 gallons per minute pumped from FL-802, Interval J

Water levels observed in packed interval J of FL-800, FL-801, and FL-802

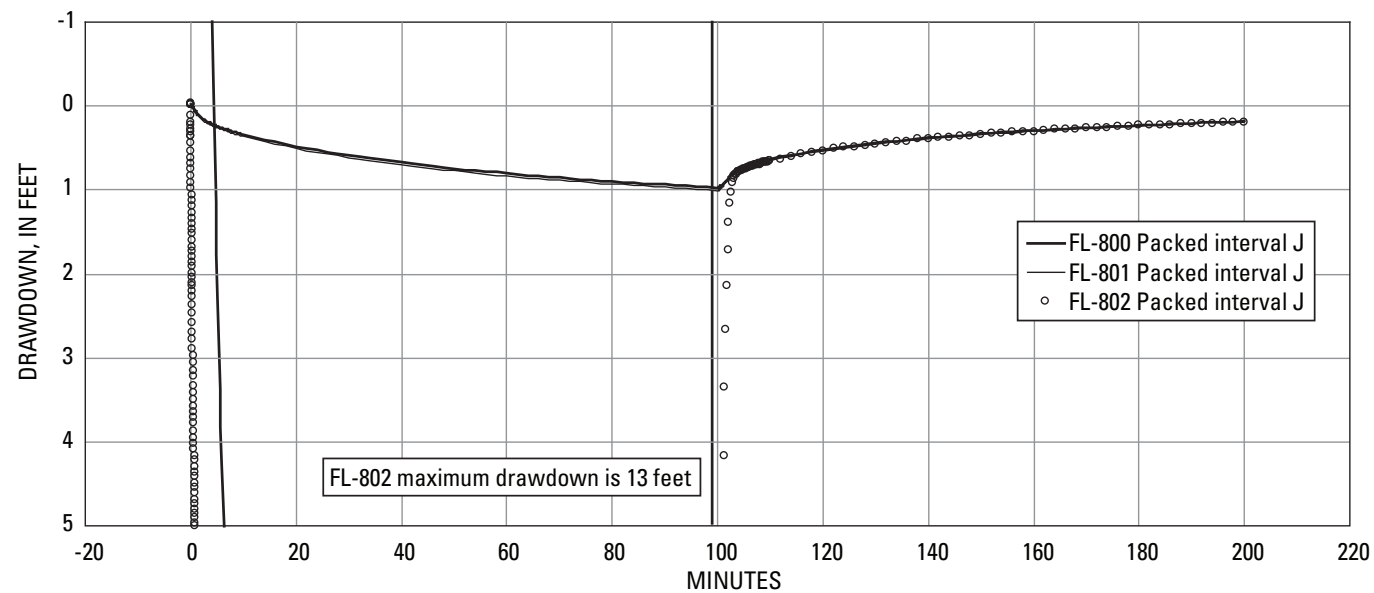

Figure 12. Changes in water levels observed in interval $\mathrm{J}$ during multiple-well constant-discharge aquifer tests at the study site in the vicinity of Waupun, Fond du Lac County, Wis.: (a) well is FL-800, (b) well is FL-801, (c) well is FL-802 (intervals are shown in figure 4). 
a)

Multiple-well constant-discharge aquifer test

4 gallons per minute pumped from FL-800, Interval K

Water levels observed in packed interval K of FL-800, FL-801, and FL-802

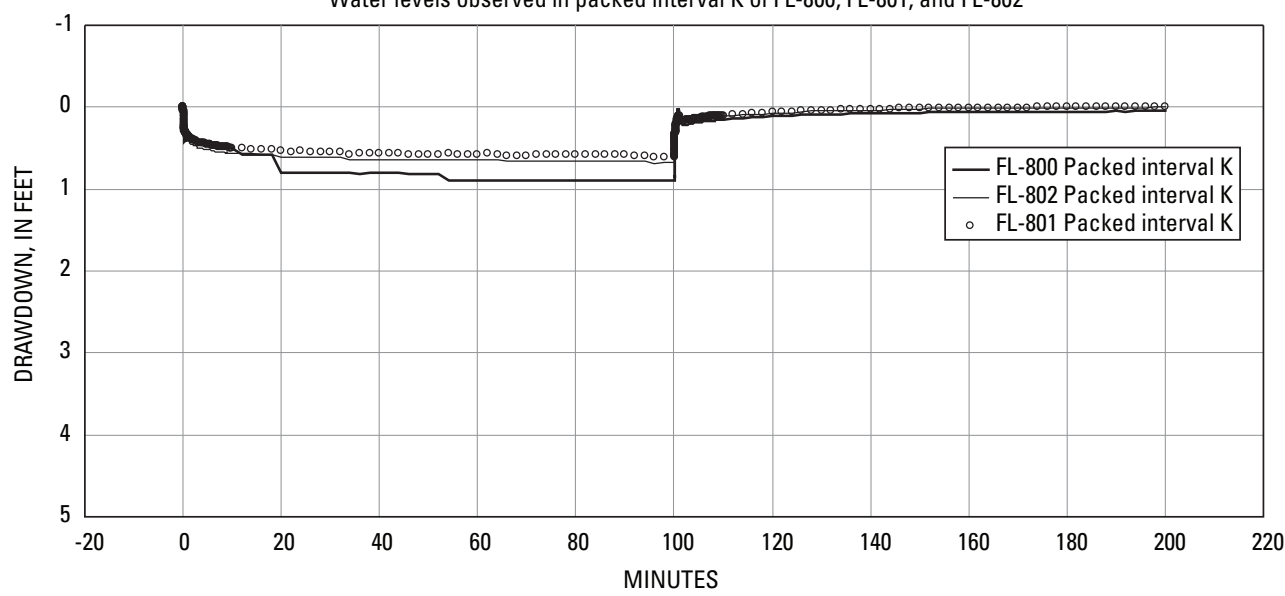

b)

Multiple-well constant-discharge aquifer test 4 gallons per minute pumped from FL-801, Interval K

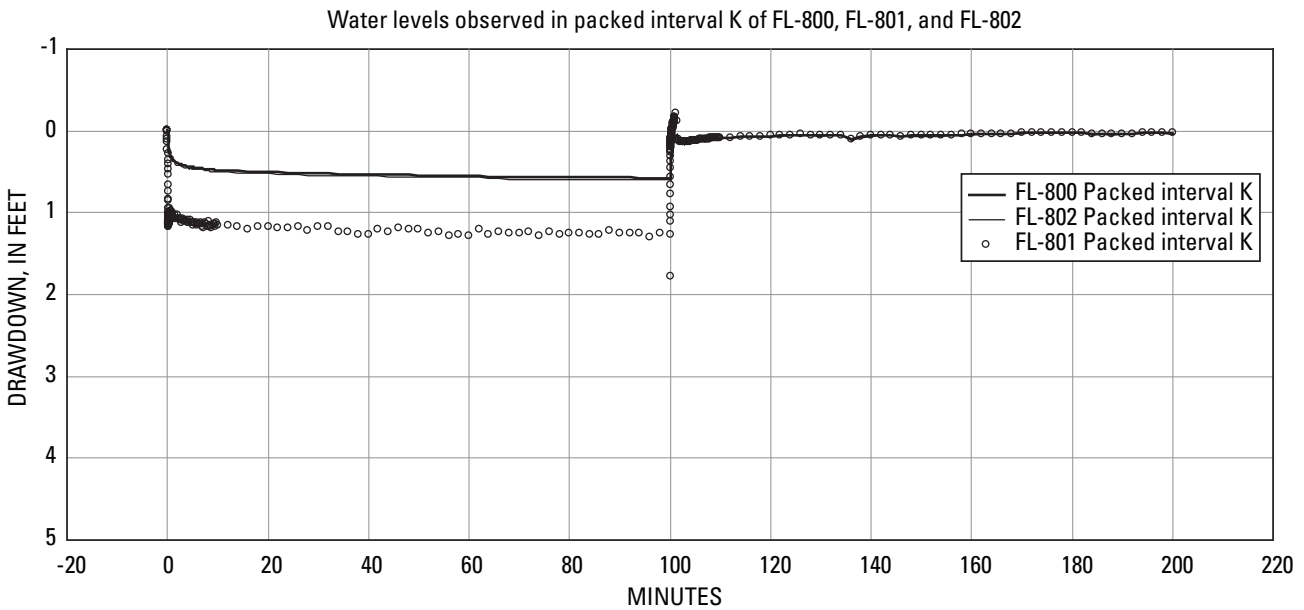

c)

Multiple-well constant-discharge aquifer test 4 gallons per minute pumped from FL-802, Interval $\mathrm{K}$

Water levels observed in packed interval K of FL-800, FL-801, and FL-802

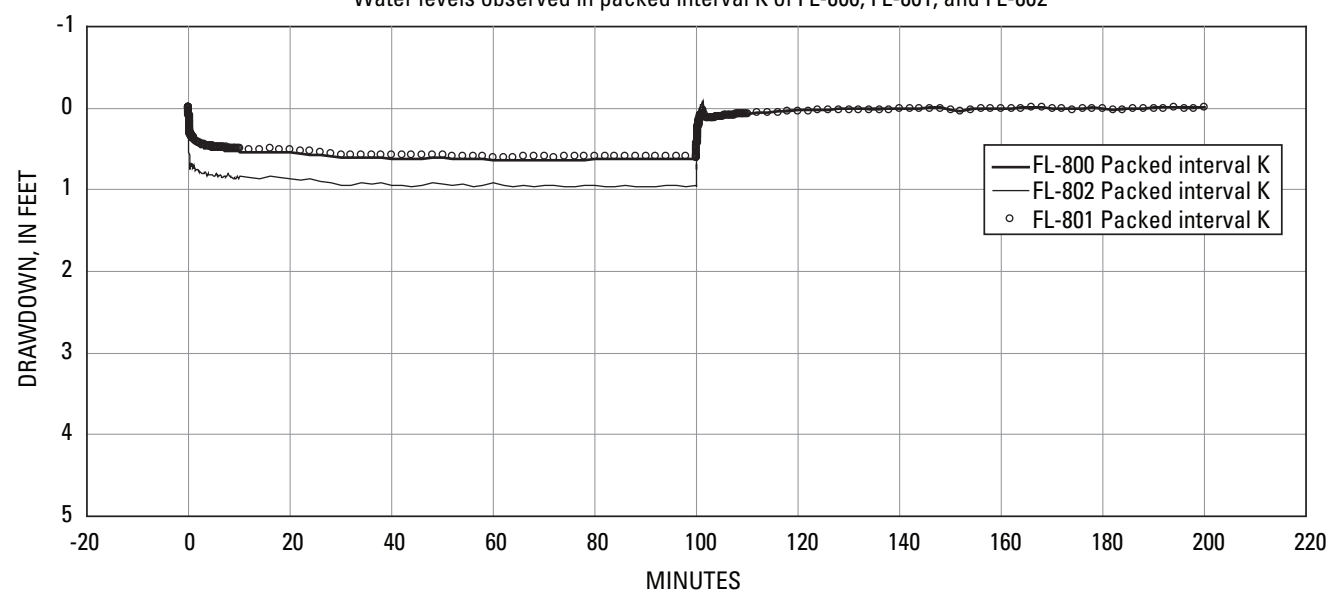

Figure 13. Changes in water levels observed in interval $\mathrm{K}$ during multiple-well constant-discharge aquifer tests at the study site in the vicinity of Waupun, Fond du Lac County, Wis.: (a) well is FL-800, (b) well is FL-801, (c) well is FL-802 (intervals are shown in figure 4). 


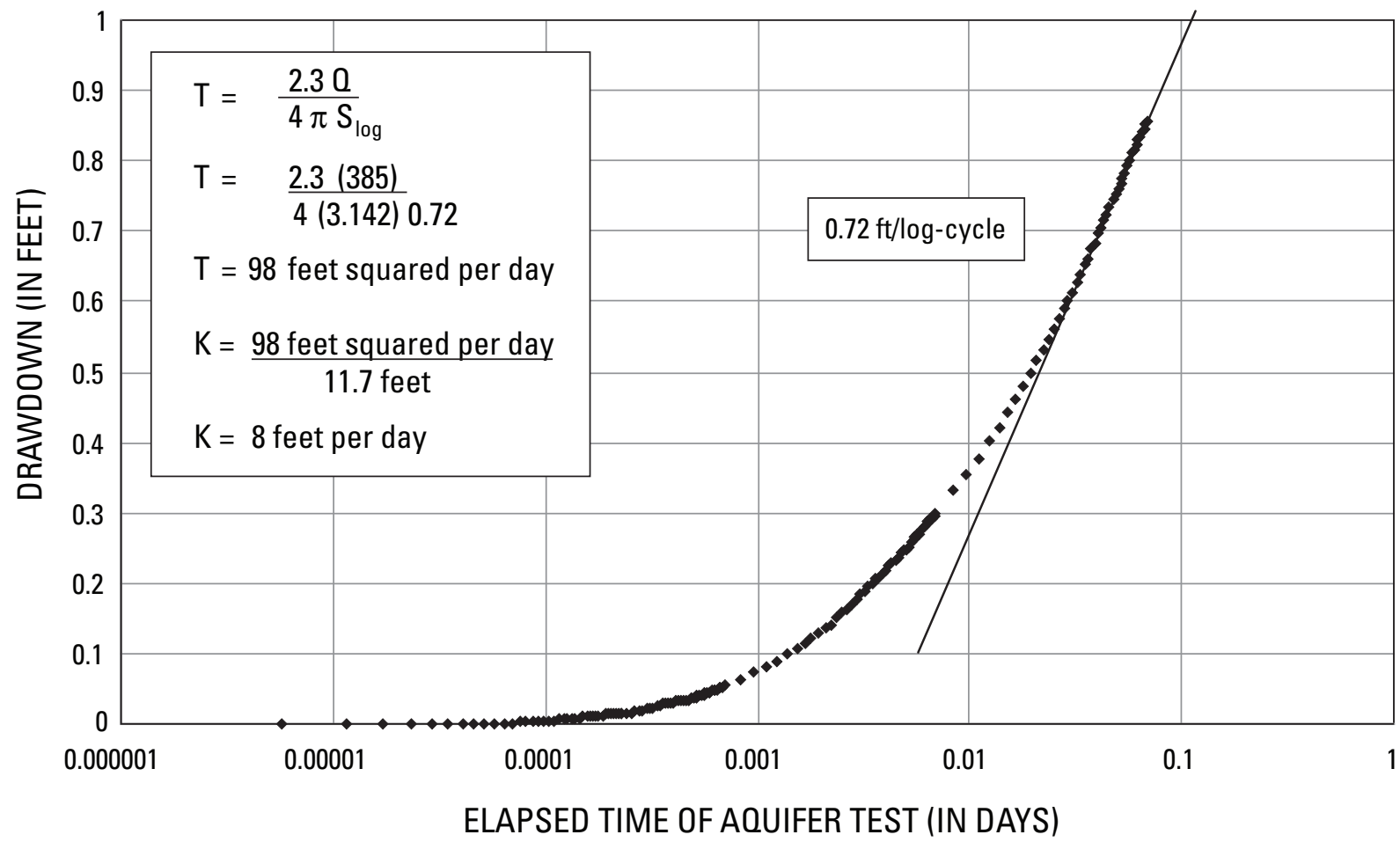

Figure 14. Multiple-well constant-discharge data collected from interval $\mathrm{J}$ of borehole FL-801 during pumping of borehole FL800 at the study site in the vicinity of Waupun, Fond du Lac County, Wis., and estimated transmissivity and horizontal hydraulic conductivity using the Cooper and Jacob equation (1946). (Intervals are shown in figure 3.) 
38 Lithostratigraphic and Hydrogeologic Characteristics of the Ordovician Sinnipee Group in the Vicinity of Waupun, Wis.

Table 11. Horizontal hydraulic conductivity of intervals in boreholes FL-800, FL-801, and FL-802 estimated from multiple-well constant-discharge aquifer tests at the study site in the vicinity of Waupun, Fond du Lac County, Wis.

[--, calculation was not possible because of unreliable data; altitude of packed intervals defined in table 4; intervals depicted in figure 7; conductivity estimated using graphical method (Cooper-Jacobs method, 1946)]

\begin{tabular}{|c|c|c|c|c|c|c|}
\hline $\begin{array}{l}\text { Pumped } \\
\text { borehole }\end{array}$ & $\begin{array}{l}\text { Observed } \\
\text { borehole }\end{array}$ & $\begin{array}{c}\text { Length of } \\
\text { tested interval } \\
\text { (feet) }\end{array}$ & $\begin{array}{c}\text { Pumpage rate } \\
\text { (cubic feet per day) }\end{array}$ & $\begin{array}{c}S_{\log } \\
\text { (foot/log-cycle) }\end{array}$ & $\begin{array}{c}\text { Transmissivity } \\
\text { (square feet } \\
\text { per day) }\end{array}$ & $\begin{array}{c}\text { Horizontal } \\
\text { hydraulic } \\
\text { conductivity } \\
\text { (feet per day) }\end{array}$ \\
\hline \multicolumn{7}{|c|}{ Packed interval J } \\
\hline \multirow[t]{2}{*}{ FL-800 } & FL-801 & 11.7 & 385 & 0.72 & 98 & 8 \\
\hline & FL-802 & 11.5 & 385 & 0.71 & 99 & 9 \\
\hline \multirow[t]{2}{*}{ FL-801 } & FL-800 & 11.5 & 385 & 0.87 & 81 & 7 \\
\hline & FL-802 & 11.5 & 385 & 0.86 & 82 & 7 \\
\hline \multirow[t]{2}{*}{ FL-802 } & FL-800 & 11.5 & 385 & 0.78 & 90 & 8 \\
\hline & FL-801 & 11.7 & 385 & 0.78 & 90 & 8 \\
\hline \multicolumn{7}{|c|}{ Packed interval K } \\
\hline \multirow[t]{2}{*}{ FL-800 } & FL-801 & 11.7 & 770 & - & -- & - \\
\hline & FL-802 & 11.5 & 770 & 0.06 & 2349 & 201 \\
\hline \multirow[t]{2}{*}{ FL-801 } & FL-800 & 11.5 & 770 & 0.13 & 1084 & 94 \\
\hline & FL-802 & 11.5 & 770 & 0.12 & 1174 & 102 \\
\hline \multirow[t]{2}{*}{ FL-802 } & FL-800 & 11.5 & 770 & 0.12 & 1174 & 102 \\
\hline & FL-801 & 11.7 & 770 & 0.08 & 1762 & 151 \\
\hline
\end{tabular}


The conductivity of interval $\mathrm{J}$, estimated using the multiple-well constant discharge test, is about 4 to 30 times that estimated using the slug test. The conductivity of interval $\mathrm{K}$ estimated using the multiple-well constantdischarge test is about 2 to 8 times that estimated using the slug test. Because the volume of the aquifer tested using the multiple-well constant-discharge test is appreciably greater than that tested using the displacement/recovery tests, the results of the multiple-well constant-discharge test are believed to better represent the true conductivity of intervals $\mathrm{J}$ and $\mathrm{K}$ in these boreholes.

\section{Anisotropy}

The response of water levels to a hydraulic stress during borehole development and to the multiple-well constant-discharge aquifer testing was generally anisotropic. The exact spatial nature of the anisotropy could not be quantified because of an insufficient number of wells at different orientations from the pumping borehole. However, the maximum amount of drawdown varied between the boreholes, as indicated by the differences in transmissivity and horizontal hydraulic conductivity calculated for the different tests (table 11), even though the pumping rates for each interval were equivalent. This indicates the anisotropic response in drawdown. During the testing of both the $\mathrm{J}$ and $\mathrm{K}$ packed intervals, the greater hydraulic response was observed between FL-800 and FL-802 in a southeastern direction. The lower hydraulic response was between FL-801 and FL-800 for these same packed intervals, corresponding to a northeastern direction, roughly orthogonal to the orientation of greater response.

\section{Summary}

The lithostratigraphic and hydrogeologic characteristics of the Ordovician Sinnipee Group were evaluated at a farm site in Fond du Lac County using a broad range of descriptive, geophysical, and hydrologic methods. The physical description of rock core from borehole FL-800 and results of the geophysical surveys (electric logs, natural gamma, caliper, neutron porosity, acoustic televiewer, heat-pulse flowmeter, single-hole directional reflection, and cross-borehole radar tomography), hydraulic tests (displacement/recovery and multiple-well constant-discharge), and limited water-quality testing in all three boreholes were evaluated and summarized.

The water type from the wells was shown to be calcium-magnesium bicarbonate; this chemistry is reflective of the carbonate-rich minerals in the Ordovician aquifer and is consistent with previous interpretations of water quality data in Wisconsin. Samples collected from intervals C, D, E, and F in borehole FL-800 were analyzed for trace elements, major ions, and organic compounds. Results of analyses indicated that the concentration of antimony in interval D exceeded the U.S. Environmental Protection Agency (USEPA) Primary Drinking Water Standard; in interval F, concentrations of aluminum and manganese exceeded USEPA Secondary Drinking Water Standards, and the concentration of sodium exceeded the USEPA Drinking Water Equivalent Level. The concentration of iron exceeded the USEPA Secondary Drinking Water Standard in samples from all four intervals. With the exception of one sample that contained trichloroethene at $1 \mu \mathrm{g} / \mathrm{L}$, all of the organic compounds analyzed were found to be below the detection limit, estimated, or qualified due to presence in a laboratory blank.

The investigation determined that at the Waupun site, the Sinnipee Group is about $183 \mathrm{ft}$ thick, overlain by $16 \mathrm{ft}$ of unconsolidated Quaternary deposits, and underlain by the Glenwood Formation. The Sinnipee Group comprises the Platteville Formation-massive dolomite (about $51 \mathrm{ft}$ thick); the Decorah Formation-dolomite and shale (about $14 \mathrm{ft}$ thick); and the Galena Dolomite-argillaceous dolomite (about $119 \mathrm{ft}$ thick). Analysis of rock core indicated that porosity for the Sinnipee Group ranged from 1.6 to 9.7 percent, bulk density ranged from 2.4 to $2.8 \mathrm{~g} / \mathrm{cm}^{3}$, and grain density ranged from 2.5 to $2.9 \mathrm{~g} / \mathrm{cm}^{3}$. Inspection of rock core indicates natural fractures (not mechanically induced as part of the coring process) were limited to about the upper $80 \mathrm{ft}$ of core and exhibited dips from 0 degrees (vertical) to 40 degrees. Three very well developed hardgrounds were identified and designated as formation or member contacts, specifically the top of the Platteville Formation, the Pecatonica Member of the Platteville Formation, and the Glenwood Formation. A fourth very well developed hardground appears related to two distinct bedding-plane partings at about $868 \mathrm{ft}$.

The results of all methods indicate that ground water in the Sinnipee Group is transmitted primarily along bedding-plane partings. Bedding-plane partings were often observed to be laterally extensive, intersecting the three boreholes-FL-800, FL-801, and FL-802 — at similar altitudes. However, these bedding-plane partings are not necessarily always hydraulically well-connected. Following development of the boreholes, 11 intervals were isolated using inflatable packers in borehole FL-800, 2 intervals in FL-801, and 2 intervals in FL-802. Results of displacement/recovery tests provided estimates of hori- 
zontal hydraulic conductivity of isolated intervals ranging from 0.3 to $61 \mathrm{ft} / \mathrm{d}$. This range includes intervals that contain bedding-plane partings and intervals that do not. Packed intervals $\mathbf{J}$ and $\mathrm{K}$ were selected for multiple-well constant-discharge testing on the basis of core evaluation and geophysical logs, and the relatively high permeability exhibited by displacement/recovery test results. The estimated horizontal hydraulic conductivity of interval K (about 100-200 ft/d) was consistently greater than interval J conductivity (about 7-9 ft/d). The conductivity of interval $\mathrm{K}$, estimated by multiple-well constant-discharge tests, was about 2 to 8 times greater than that estimated by the slug test. The conductivity of interval $\mathrm{J}$ at about $810 \mathrm{ft}$, estimated by multiple-well discharge tests, was about 4 to 30 times greater than that estimated by the slug test. The test results are largely consistent with the interpretation of the heat-pulse flowmeter data that the partings present in interval $\mathrm{K}$ have the greatest relative permeability in the borehole, representing from about 60 to 90 percent of the total permeability. During the multiple-well constant-discharge tests, the greater hydraulic response was observed in a southeastern direction. The lower hydraulic response was observed in a northeastern direction, roughly orthogonal to the orientation of greater response.

Managing and protecting the ground-water supply in the shallow Sinnipee Group aquifer in Fond du Lac County can take advantage of the understanding of the hydrogeologic characteristics resulting from this project.

\section{Acknowledgments}

The authors would like to acknowledge the USGS Coal Branch drilling crew who drilled three boreholes and cut rock core at the study site. The three boreholes were developed with the assistance of USEPA personnel and equipment. The expertise provided by Frederick Paillet, Richard Hodges, and John Lane of the USGS is appreciated in conducting borehole geophysics and for providing interpretation of their logs and tests. Michael Sargent and Zakaria Lawemi of the Illinois State Geological Survey are thanked for providing lithologic description and stratigraphic interpretation of the recovered rock core, and Patrick Mills of the USGS is thanked for conducting the physical analysis on rock-core samples. The authors appreciate the assistance of Gary Cygan of the USEPA in sample collection. David Saad and Daryll Pope of the USGS are thanked for their review and interpretation of aquifer-test data, and Earl Greene and Paul Juckem of the USGS are thanked for providing technical reviews of the report. Appreciation is extended to Ruth Larkins of the USGS, New Jersey Publications Service Center for the editorial review of the report. Kevin Breen, Acting Reports Improvement Advisor for the USGS Northeastern Region, provided very helpful comments during final review of the report. Finally, the authors would like to thank the Smedema Family for providing access to their farm and for their assistance over the several years of activity at the site.

\section{References}

Batten, W.G., 2004, Preliminary Paleozoic geologic map of Fond du Lac County, Wisconsin: University of Wisconsin-Extension, Wisconsin Geological and Natural History Survey Open-File Report 2004-23, scale 1:100,000.

Batten, W.G., Yeskis, D.J., and Dunning, C.P., 1999, Hydrogeologic properties of the Ordovician Sinnipee Group at test well BN-483, Better Brite Superfund Site, De Pere, Wisconsin: U.S. Geological Survey WaterResources Investigations Report 99-4199, 19 p.

Brown, T.A., Dunning, C.P., and Sharpe, J.B., 2000, Altitude, depth, and thickness of the Galena-Platteville bedrock unit in the subcrop area of Illinois and Wisconsin: U.S. Geological Survey Water-Resources Investigations Report 97-4054-C, 4 pl.

Conlon, T.D., 1998, Hydrogeology and simulation of ground-water flow in the sandstone aquifer, northeastern Wisconsin: U.S. Geological Survey Water-Resources Investigations Report 97-4096, 60 p., 1 pl.

Cooper, H.H., Jr., and Jacobs, C.E., 1946, A generalized graphical method for evaluating formation constants and summarizing well-field history: American Geophysical Union Transactions, v. 27, no. 4, p. 526-534

Day-Lewis, F., and Lane, J.W., Jr., 2003, Use of crosshole radar tomograms for geostatistical estimation and simulation of interwell permeability—Limitations due to tomographic resolution [abs.]: Eos Transactions, American Geophysical Union, v. 84, no. 46, Fall Meeting Suppl., Abstract H21F-02.

Falk, L., 1992, Directional borehole antenna theory: Stockholm, Sweden, Stripa Project 92-16, SKB, 138 p.

Freeze, R.A., and Cherry, J.A., 1979, Groundwater: Prentice-Hall. N.J., 604 p.

Hurlbut, C.S., Jr., and Klein, C., 1977, Manual of Mineralogy (after James D. Dana): New York, John Wiley and Sons, $532 \mathrm{p}$. 
Hvorslev, M.J., 1951, Time lag and soil permeability in ground water observation: U.S. Army Corps of Engineers Waterway Experimentation Station, Bulletin 36.

Ivansson, S., 1984, Crosshole investigations - tomography and its application to crosshole seismic measurements: Stockholm, Sweden, Stripa Project IR-84-08.

Kay, R.T., Mills, P.C., Dunning, C.P., Yeskis, D.J., Ursic, J.R., and Vendl, M., 2004, A cross-site comparison of methods used for hydrogeologic characterization of the Galena-Platteville aquifer in Illinois and Wisconsin, with examples from selected Superfund sites: U.S. Geological Survey Scientific Investigations Report 04-5136, $241 \mathrm{p}$.

Kay, R.T., Yeskis, D.J., Lane, J.W., Jr., Mills, P.C., Joesten, P.K., Cygan, G.L., and Ursic, J.R., 2000, Geology, hydrology, and ground-water quality of the upper part of the Galena-Platteville aquifer at the Parson's Casket Hardware Superfund site in Belvidere, Illinois: U.S. Geological Survey Water-Resources Investigations Report 99-4138, 43 p.

Kammerer, P.A., Jr., 1984, An overview of ground-water quality data in Wisconsin: U.S. Geological Survey Water-Resources Investigations Report 83-4239, 58 p.

Keys, W.S., 1990, Borehole geophysics applied to ground-water investigations: U.S. Geological Survey Techniques of Water Resources Investigations Book 2, Chapter E2, 150 p.

Kruseman, G.P., and de Ridder, N.A., 1991, Analysis and evaluation of pumping test data, ( $2^{\mathrm{d}} \mathrm{ed}$.): Wageningen, The Netherlands, International Institute for Land Reclamation and Improvement, $377 \mathrm{p}$.

Lane, J.W., Jr., Haeni, F.P., and Williams, J.H., 1994, Detection of bedrock fractures and lithologic changes using borehole radar at selected sites: Kitchener, Ontario, International Conference of Ground Penetrating Radar, $5^{\text {th }}$, June 12-16, 1994, [Proceedings], p. 577-592.

Lane, J.W., Jr., Williams, J.H., Johnson, C.D., Savino, Sr. D.-M., and Haeni, F.P., 2002, An integrated geophysical and hydraulic investigation to characterize a fracturedrock aquifer, Norwalk, Connecticut: U.S. Geological Survey Water-Resources Investigations Report 01-4133, 97 p. (Accessed July 19, 2007, at http://water.usgs. gov/ogw/bgas/publications/wri014133/)

Martin, L., 1965, The Physical Geography of Wisconsin: University of Wisconsin Press, 636 p.

Mudrey, M.G., Jr., Brown, B.A., and Greenburg, J.K., 1982, Bedrock geologic map of Wisconsin: University of Wisconsin-Extension, Wisconsin Geological and Natural History Survey, scale 1:1,000,000.
Newport, T.G., 1962, Geology and ground-water resources of Fond du Lac County, Wisconsin: U.S. Geological Survey Water-Supply Paper 1604, 52 p.

Olcott, P.G., 1992, Ground Water Atlas of the United States, Segment 9, Iowa, Michigan, Minnesota, Wisconsin: U.S. Geological Survey Hydrologic Investigations Atlas 730-J, 31 p.

Paillet, F.L., 1994, Application of borehole geophysics in the characterization of flow in fractured rocks: U.S. Geological Survey Water-Resources Investigations Report 93-4214, 97 p.

Paillet, F.L., 1995, Using borehole flow logging to optimize hydraulic test procedures in heterogeneous fractured aquifers: Hydrogeology Journal, v. 3, no. 3, p. 4-20.

Paillet, F.L., 1998, Flow modeling and permeability estimation using borehole flow logs in heterogeneous fractured formations: Water Resources Research, v. 34, no. 5, p. 997-1010.

Paillet, F.L., 2000, A field technique for estimating aquifer parameters using flow log data: Ground Water, v. 38, no. 4, p. 510-521.

Paillet, F.L., and Crowder, R.E., 1996, A generalized approach for the interpretation of geophysical well logs in ground-water studies-theory and application: Ground Water, v. 34, no. 5, p. 883-898.

Paillet, F.L., Hess, A.E., Cheng, C.H., and Hardin, E., 1987, Characterization of fracture permeability with high-resolution vertical flow measurements during borehole pumping: Ground Water, v. 25, no. 1, p. 28-40.

Paillet, F.L., and Reese, R.S., 2000, Integrating borehole logs and aquifer tests in aquifer characterization: Ground Water, v. 38, no. 5, p. 713-725.

Saad, D.A., 1996, Ground-water quality in the western part of the Cambrian-Ordovician aquifer in the Western Lake Michigan Drainages, Wisconsin and Michigan: U.S. Geological Survey Water-Resources Investigations Report, 96-4231, 40 p.

Singha, K., Kimball, K., and Lane, J.W., Jr., 2000, Borehole radar methods: tools for characterization of fractured rock: U.S. Geological Survey Fact Sheet 054-00, 4 p.

Piper, A.M., 1944, A graphic procedure in the geochemical interpretation of water analyses: American Geophysical Union Transactions, v. 25, p. 914-923.

The Geological Society of America, 1980, GSA Rock Color Chart, Special Publication, 16 p. 
U.S. Environmental Protection Agency, 2000, Drinking water standards and health advisories: U.S. Environmental Protection Agency, Washington, D.C., EPA 822-B-00-001, Summer 2000, 12 p.

U.S. Environmental Protection Agency and U.S. Geological Survey, 1996, Test well drilling, coring, water sampling and analysis plan for test wells at Smedema Farm near Waupun, Wisconsin: Chicago, Ill., U.S. Environmental Protection Agency, unpublished, 27 p.

Williams, J.H., and Lane, J.W., 1998, Advances in borehole geophysics for ground-water investigations: U.S. Geological Survey Fact Sheet 002-98, 4 p.

Wisconsin State Climatologic Office, accessed 2002, at URL http://mrcc.sws.uiuc.edu/climate_midwest/ historical/precip/wi/472839_psum.html.

Zaporozec, A., and Cotter, R.D., 1985, Major groundwater units of Wisconsin: University of Wisconsin-Extension, Geological and Natural History Survey Educational Series Number 28, 20 p. 


\section{Appendixes}


Appendix 1. Laboratory procedures for porosity and density analysis of rock core samples (Pat Mills, U.S. Geological Survey Illinois Water Science Center, written commun., 1996)

1. Select approximately $1 / 4$-foot long core samples from core box.

a. Label top of selected core samples (side closest to land surface- minimum depth) with "T"; label with sample number. Use permanent marker.

b. Wrap core section in aluminum foil or place in plastic sandwich bag.

2. Using the Mettler Scale, remove the cores from the aluminum foil or plastic bags and measure the initial weight $\left(\mathrm{W}_{\mathrm{i}}\right.$, in grams) of the solid core samples (save, but do not weigh any small fragments of the core lost during handling). Be sure the scale is calibrated, leveled, and zeroed before weighing.

3. Place core samples long side upward in a small, metal, sample canister.

4. Place the core samples (up to about 5 core samples) in a dry, metal, sample canister and place in oven.

5. Place desiccated core samples (and fragments) on Mettler Scale and determine dry weight of samples $\left(\mathrm{W}_{\mathrm{d}}\right.$, in grams)

6. Fill the vacuum jar about $3 / 4$ full of deionized water (or tap water, if deionized water is unavailable). Avoid agitation (aeration) of the water.

7. Check the vacuum pump for proper volume and quality (moisture-free) of pump oil. Replacement oil should be engineered specifically for use in vacuum pumps. Discard used oil in proper container for disposal.

8. Attach cartridge of properly dried desiccant (Dririte) to vacuum pump. Desiccant should appear light gray and translucent in clarity. Hydrated desiccant is dark brown to black and nearly opaque. Desiccant can be reconditioned by heating 1-2 hours at 200-225 degrees Celsius.

9. Place the core sample (up to about 5 core samples) in the vacuum jar, ensuring the core is fully submersed in the water. Cores should be placed in the vacuum jar in the metal canisters or plastic bags to contain any fragments that may break off during saturating. The fragments must later be weighed along with the saturated cores. Submerse remainder of core samples in a water-filled container while first set of samples are in vacuum jar.

10. Saturate the core sample under vacuum for a minimum of 8 hours. Pre- or post-saturate the core samples in water under ambient atmospheric pressure or vacuum with the pump turned off for a minimum of 48 hours. If air bubbles are noted in the water or emanating from the core samples while under vacuum (with pump turned on), continue pumping under vacuum until no bubbles are observed. Note that there may be some air bubbles trapped under the cores or between the metal canisters or plastic bags; these can be released by gently shaking or rotating the vacuum jar.

11. Remove the core samples and gently remove excess water from the core surface by hand wiping; avoid siphoning water from the interior of the core.

12. Weigh the saturated cores $\left(\mathrm{W}_{\mathrm{s}}\right.$, in grams) and any fragments of the core collected in the meal sample canister or plastic bags.

13. Mount appropriately sized displacement chamber (smallest chamber the core sample will fit in) vertically on a laboratory ring stand. Fill with deionized or tap water to level above the discharge spigot. Let water level equilibrate to level of spigot.

14. Empty and dry collection vessel (graduated cylinder or flask) of appropriate size to collect all water discharged from the displacement chamber (generally about 100 milliliter, but run a test sample first).

15. Slowly lower the saturated core sample into the displacement chamber, ensuring no loss of water over the top of the chamber or oscillation of the water surface, thus allowing an excess volume of water to discharge through the spigot. Determine the volume of all core samples in one run of samples. After each measurement, cover the individual collection vessel with laboratory sealing tape (to prevent evaporation of the water) and label the vessel with the sample identification number. 
Appendix 1. Laboratory procedures for porosity and density analysis of rock core samples (Pat Mills, U.S. Geological Survey Illinois Water Science Center, written commun., 1996)—Continued.

16. Measure the volume $\left(\mathrm{V}_{\mathrm{t}}\right.$, in milliliters) of the displaced water. Measure using a 10 milliliter pipette; measurements should be accurate to \pm 0.05 milliliters.

17. Place the saturated cores in the brass-wire harness attached to the triple-beam balance (calibrate and zero the balance before hand) and lower into a water-filled vacuum jar until fully submersed. Record the saturated weight in water $\left(\mathrm{W}_{\mathrm{w}}\right.$, in grams). If the weight exceeds the 600 -gram limit of the balance, estimate the total weight and note the accuracy of the estimate on the laboratory record sheet and in the remarks section of the sample-calculation sheet.

18. Estimate the relative volume $\left(\mathrm{AV}_{\mathrm{p}}\right)$ of vesicle and vugs (diameter greater than $1 / 4$-inch) on the surface of the cores:

$$
\begin{aligned}
& 1 \text { - smooth } \\
& 2 \text { - slightly vesicular } \\
& 3 \text { - moderately vesicular } \\
& 4 \text { - very vesicular, slightly vuggy } \\
& 5 \text { - moderately vuggy } \\
& 6 \text { - very vuggy }
\end{aligned}
$$

19. Calculate the following values:
a. $\mathrm{W}_{\mathrm{p}}$ (weight of water in pores $=\mathrm{V}_{\mathrm{p}}$, volume of water in pores, in cubic centimeter): $\quad \mathrm{W}_{\mathrm{p}}=\mathrm{W}_{\mathrm{s}}-\mathrm{W}_{\mathrm{d}}$
b. Porosity ( $\mathrm{P}$, in percent)
$\mathrm{P}=\mathrm{V}_{\mathrm{p}} / \mathrm{V}_{\mathrm{t}}$
c. Bulk density (BD, in grams/cubic centimeter)
$\mathrm{BD}=\mathrm{W}_{\mathrm{s}} / \mathrm{V}_{\mathrm{t}}$
d. Grain density (GD, in grams/cubic centimeter)
$\mathrm{GD}=\mathrm{W}_{\mathrm{d}} / \mathrm{V}_{\mathrm{t}}$
e. Bulk specific gravity ( $\mathrm{SG}$, in grams)
$\mathrm{SG}=\mathrm{W}_{\mathrm{d}} /\left(\mathrm{W}_{\mathrm{s}}-\mathrm{W}_{\mathrm{w}}\right)$ 
Appendix 2-1. Water levels observed in boreholes FL-800, FL-801, and FL-802 during pumping of Interval $\mathrm{J}$ of FL-800.

\section{MULTIPLE WELL, CONSTANT DISCHARGE TEST: INTERVAL J OF FL-800}
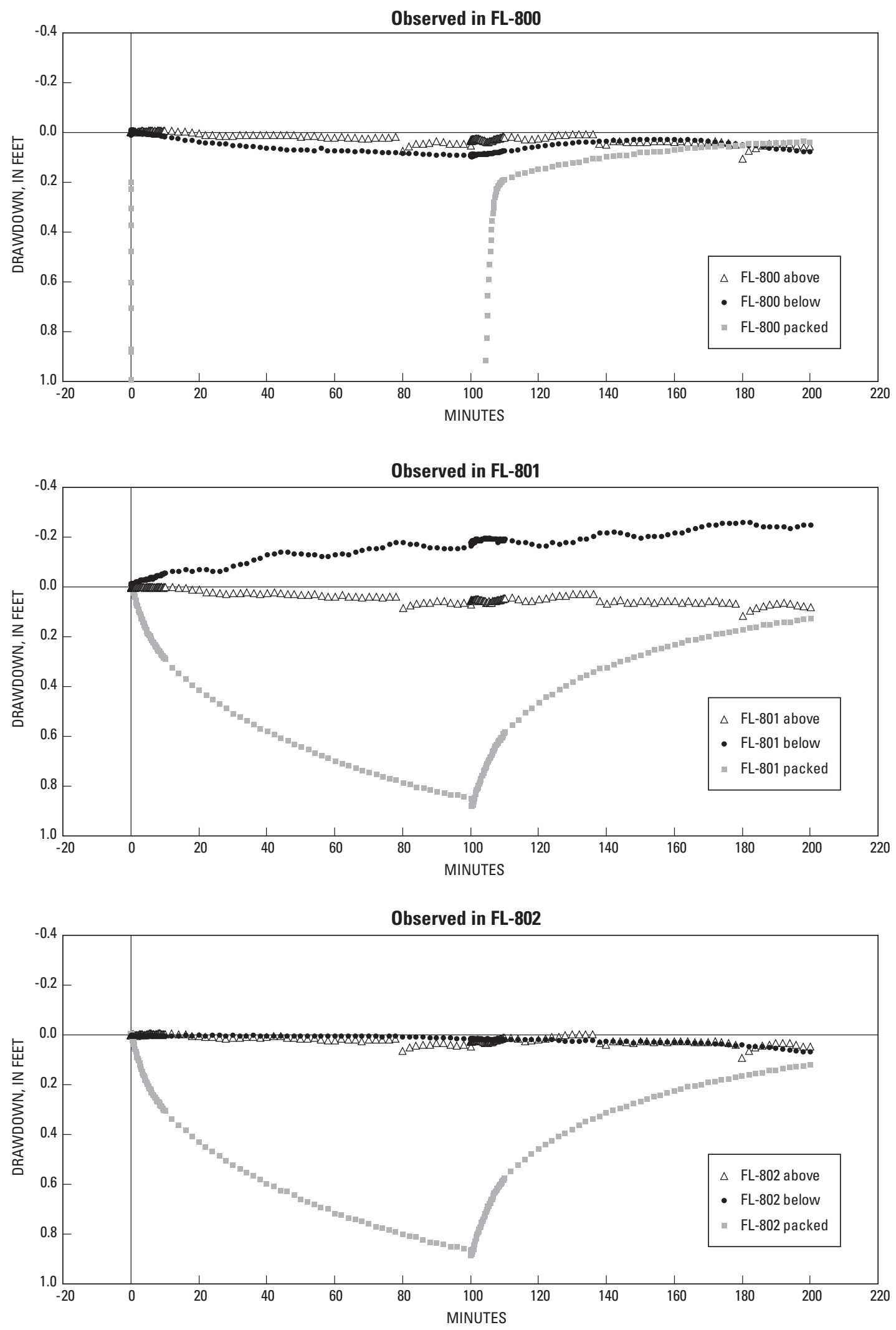
Appendix 2-2. Water levels observed in boreholes FL-800, FL-801, and FL-802 during pumping of Interval K of FL-800.

MULTIPLE WELL, CONSTANT DISCHARGE TEST: INTERVAL K OF FL-800
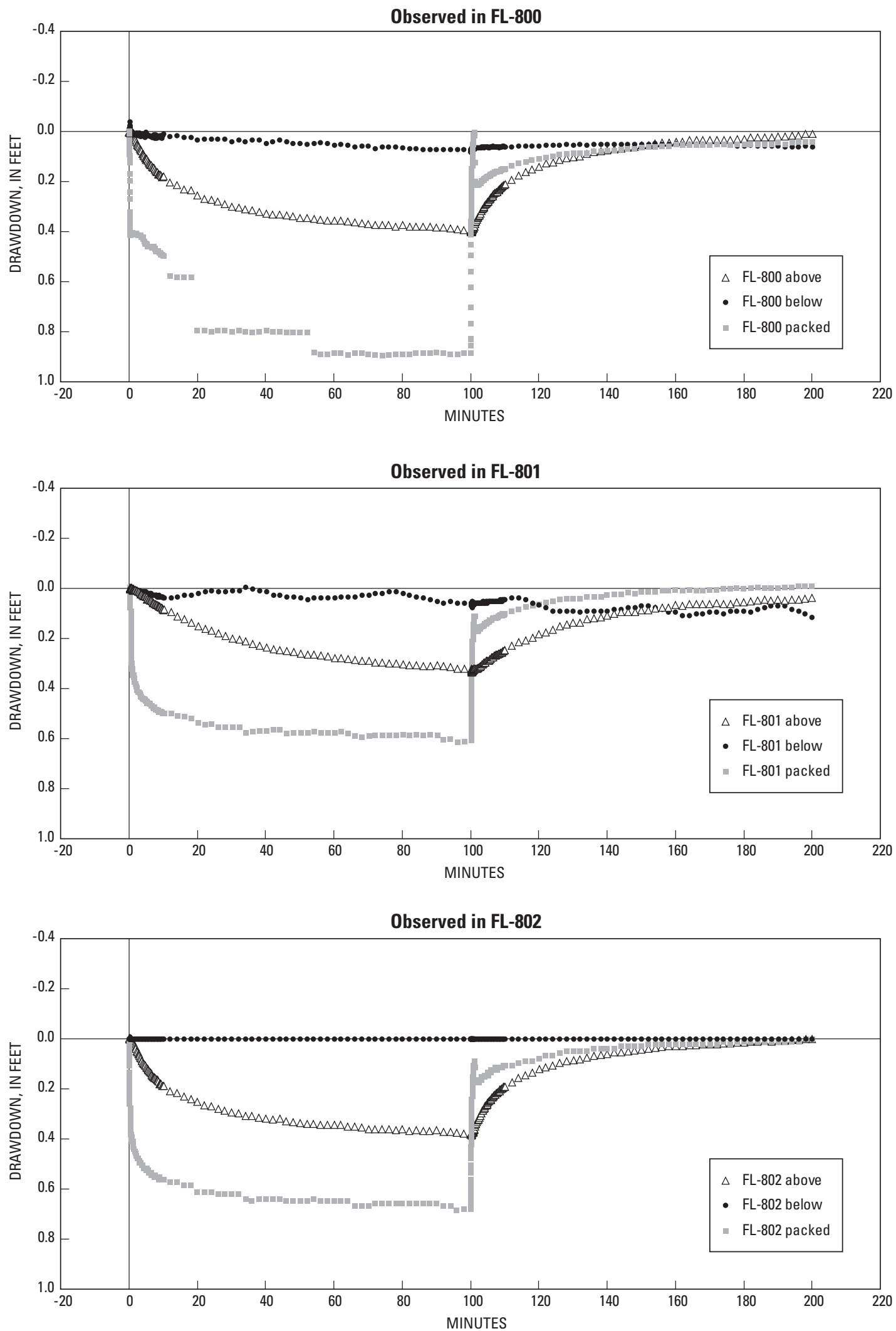
Appendix 2-3. Water levels observed in boreholes FL-800, FL-801, and FL-802 during pumping of Interval J of FL-801.

MULTIPLE WELL, CONSTANT DISCHARGE TEST: INTERVAL J OF FL-801
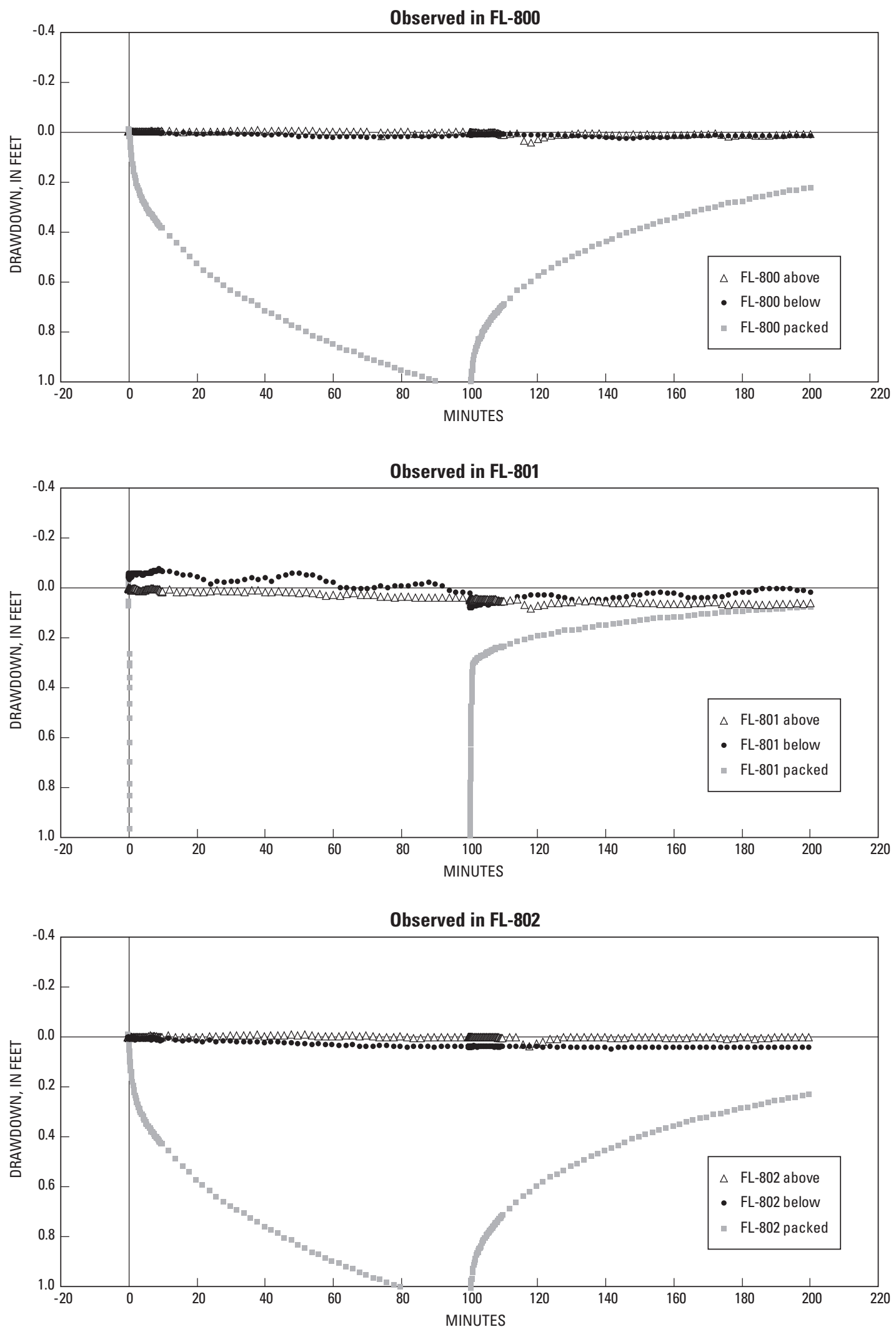
Appendix 2-4. Water levels observed in boreholes FL-800, FL-801, and FL-802 during pumping of Interval K of FL-801.

MULTIPLE WELL, CONSTANT DISCHARGE TEST: INTERVAL K OF FL-801
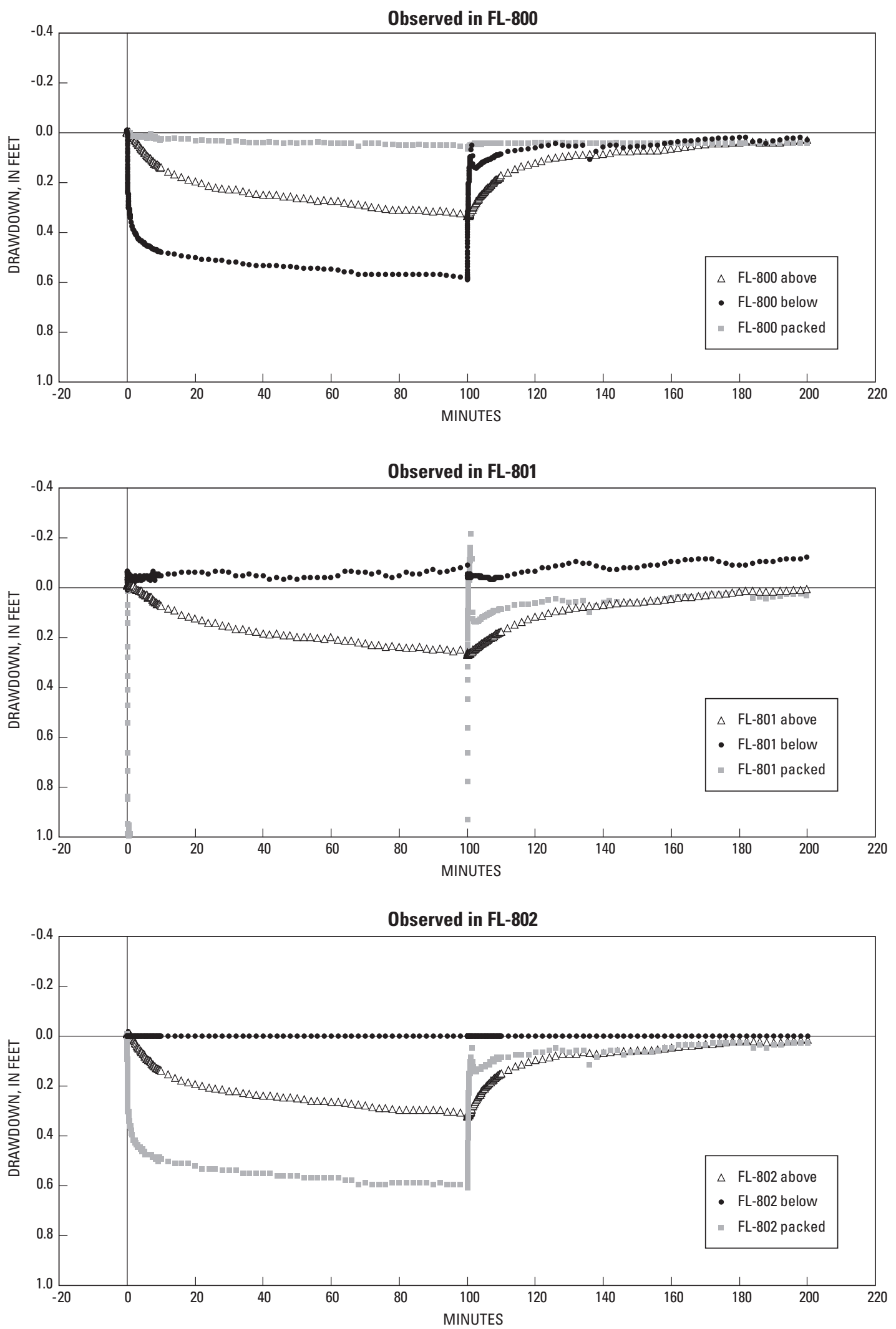
50 Lithostratigraphic and Hydrogeologic Characteristics of the Ordovician Sinnipee Group in the Vicinity of Waupun, Wis.

Appendix 2-5. Water levels observed in boreholes FL-800, FL-801, and FL-802 during pumping of Interval J of FL-802.

MULTIPLE WELL, CONSTANT DISCHARGE TEST: INTERVAL J OF FL-802
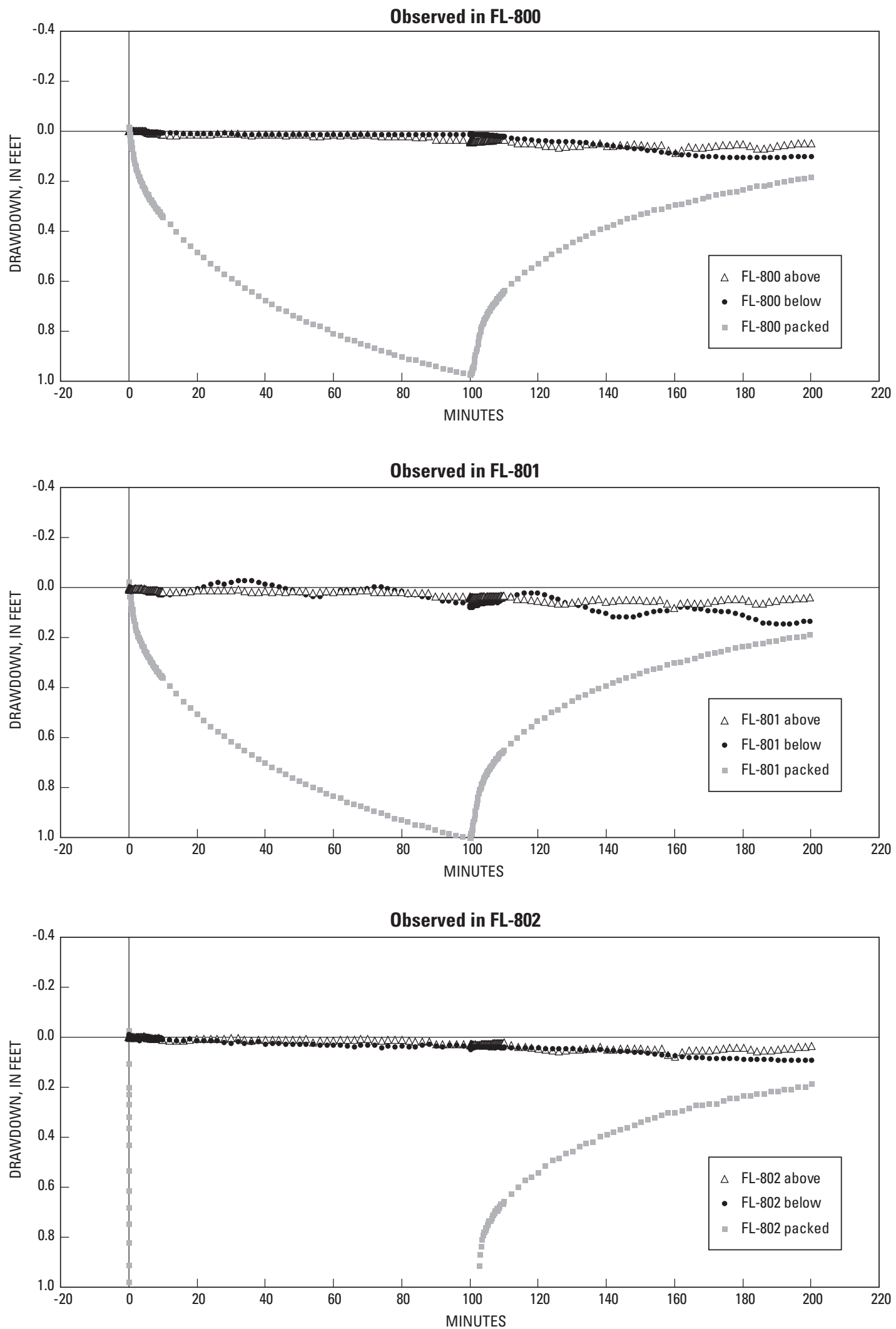
Appendix 2-6. Water levels observed in boreholes FL-800, FL-801, and FL-802 during pumping of Interval K of FL-802.

MULTIPLE WELL, CONSTANT DISCHARGE TEST: INTERVAL K OF FL-802
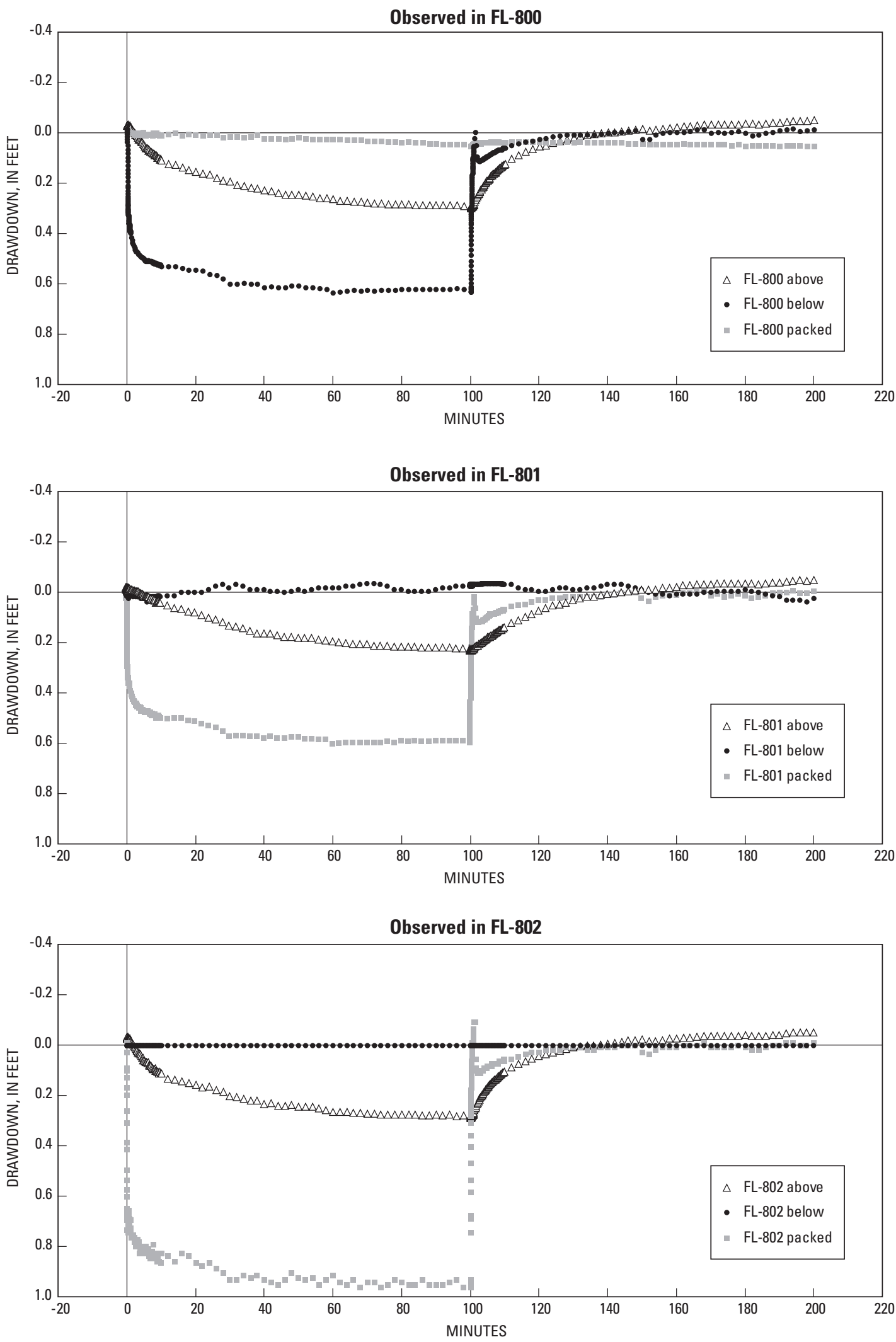

